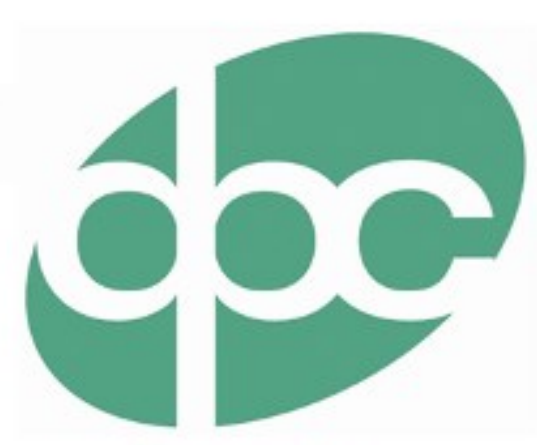

DigitalPreservationCoalition

\title{
The BitList 2020
}

The Global List of Digitally

Endangered Species

Second Edition

Revised

November 2020 


\section{Executive Summary}

The Global List of Digitally Endangered Species - The BitList - offers an accessible snapshot of the concerns expressed by the global digital preservation community with respect to the risks faced by diverse types of digital content in varied conditions and contexts. It provides an elementary assessment of the imminence and significance of the dangers faced by different, and at times overlapping classifications of digital materials. By identifying the urgency of action and significance of content, The BitList draws attention to those digital materials which, in the view of the global digital preservation community, require urgent action if they are to remain viable.

The list is derived directly from the practical experience of professionals with responsibility to maintain access to content over time: it is their voice which The BitList represents. They come from around the world and from many different sectors. It is not a top-down or theoretical exercise, nor does it serve a political or commercial interest. At a fundamental level, items appear on the list because an established and experienced professional within the digital preservation community has struggled to preserve access to this content and has called for it to be included.

The categories and classifications of content are broad in order that the list can be digested quickly. This accessibility comes at a cost to specificity. The entries and recommendations for action are imprecise so their urgency is amplified by the presence of aggravating factors or ameliorated in the presence of good practice. Entries overlap. Any given digital object may appear under multiple headings depending on technology, resourcing or organizational context. These overlapping classifications mean that objects may be at greater risk than initially suggested, and that actions to tackle the risks are potentially more complex. A condensed action plan is suggested for every entry.

First and foremost, The BitList is an advocacy tool. It emerged as a recommendation from the DPC's Advocacy and Community Engagement Sub-Committee and exists to inform priorities in the allocation of resources and support policy-development where this may be needed. It is intended as an ongoing framework of assessment which highlights risks and provides a basis for the celebration insofar as challenges, once identified, will be resolved and reported in subsequent years. The framework is also intended to become more specific over time, and thus more direct in recommendations.

The BitList has three main audiences and three related functions:

- $\quad$ as an advocacy tool, The BitList seeks to influence the technology sector and senior leaders within corporations and agencies of all kinds, giving them an honest but accessible account of the progress and weaknesses that the digital preservation community perceives. It seeks to influence them to invest credibly and plan with a more informed sense of the risks that are faced by digital materials in the longer term;

- as a practical comment on the challenges faced across the digital preservation community, The BitList provides a rudimentary but practically informed development roadmap, whether for researchers in academic institutions or commercial and semi-commercial agencies who seek to bring products to the market. It invites them to consider, and where possible resolve, the challenges that are identified here and offers credit as solutions are progressed.

- as a state-of-the-art report, The BitList provides introductory and current guidance for the digital preservation community. This is especially useful for new entrants as well as teachers so that they are prepared the challenges and opportunities that arise in the practice of digital preservation. It also supports professionals of long standing that may be approaching new challenges or content for the first time. 
The BitList is subject to a comprehensive review every two years with an interim progress report and commentary in alternate years. This schedule explicitly complements the biannual cycle of the Digital Preservation Awards. The BitList was first produced in 2017 and updated in 2018. A complete revision was published in 2019 which greatly expanded the list. The BitList 2020 offers a brief update and reflection on state of the art since then.

The entries on The BitList 2019 were generated through an open nomination process in July and August 2019 in which members of the digital preservation community around the world were invited to express concerns in relation to content for which they are responsible, and also to identify significant content where, in their view, responsibility was uncertain or capability in doubt. These submissions were combined with entries from the 2017 and 2018 list and were then assessed by a jury which reviewed the imminence of the threats, the significance of loss and the efforts required to preserve the materials nominated. In one form or another it passed been through six stages of review between open nomination and publication:

- Eligibility check by DPC staff

- Credibility check by 'First Sift' Jury

- Expert review by Full Jury

- Panel Review by Full Jury meeting in plenary

- Peer review By Full Jury

- Sign off by DPC staff

The 2020 review is an opportunity to reflect on the state of the art of digital preservation but is much less ambitious than the 2019 statement. It adds a layer of commentary from the DPC staff drawing on our experience within the digital preservation community about trends and innovations and how they have impacted on each entry in turn. Seventeen items on the list are identified as trending towards greater risk, one to reduced risk.

By its nature, The BitList is always a provisional statement. The extent of the digital domain, the complexity of the threats, and the sophistication of emerging solutions mean that no process could ever fully capture the risks and challenges faced by digital content around the world. It is published and reviewed on the understanding that new risks are continuously arising; every day and (inevitably) between editions of The BitList. The Jury also recognizes that differences in emphasis and subtleties of local context may well have been overlooked, and that material changes may occurred during the process of compilation but too late for inclusion. Consequently, corrections and additions are welcome.

A full review will commence almost immediately from the 2020 publication, in time for a major revision which will be published in November 2021. 


\section{Table of Contents}

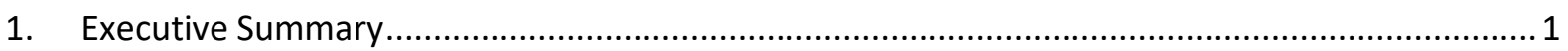

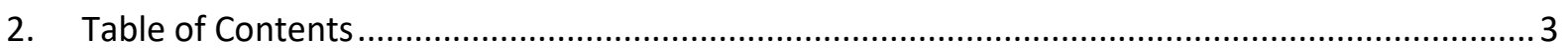

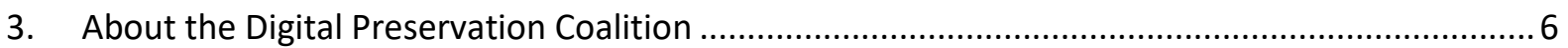

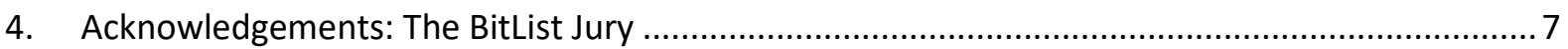

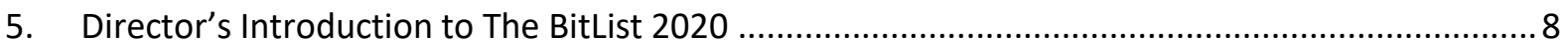

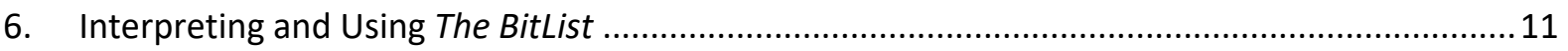

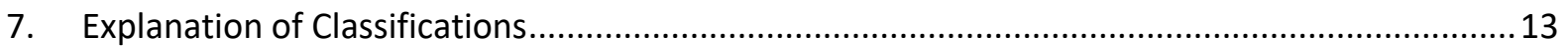

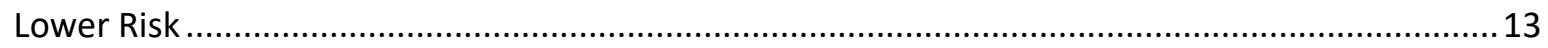

Vulnerable

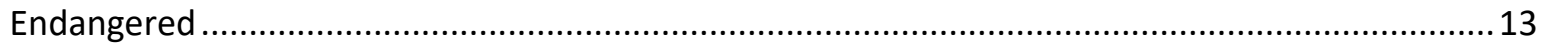

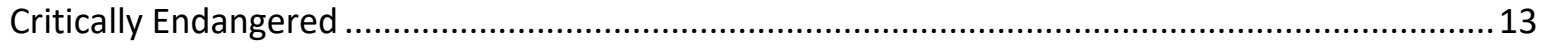

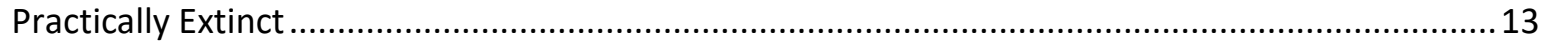

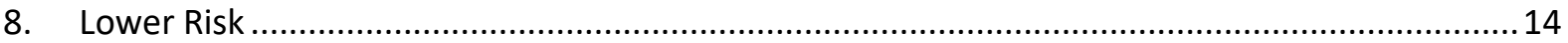

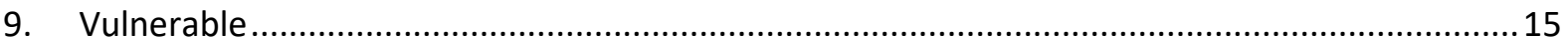

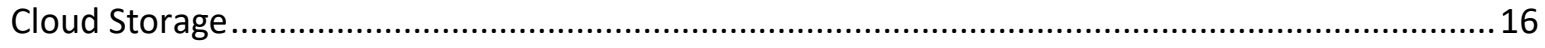

Content on cloud video services produced by the service provider ............................................. 17

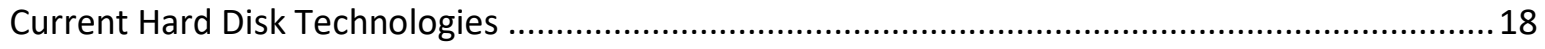

Digital recordings published via cloud-based music sharing platforms........................................... 19

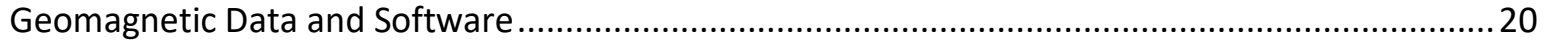

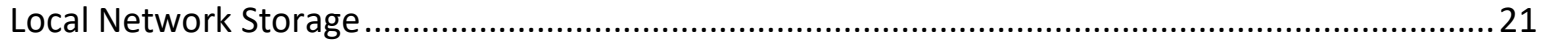

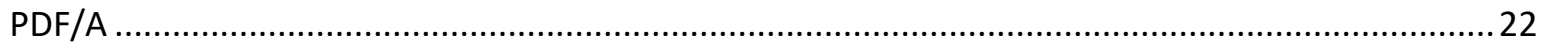

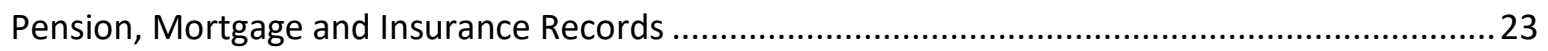

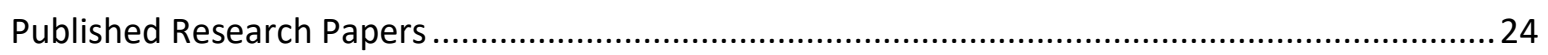

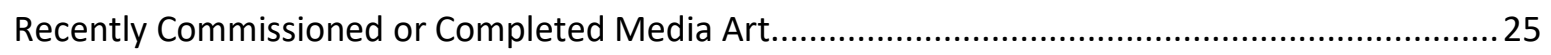

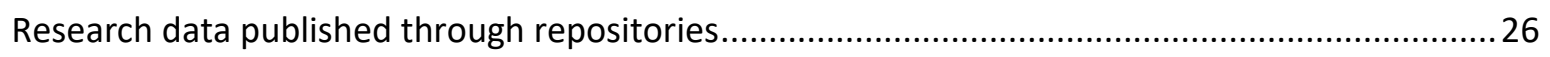

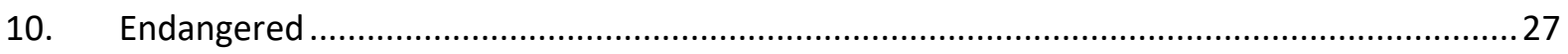

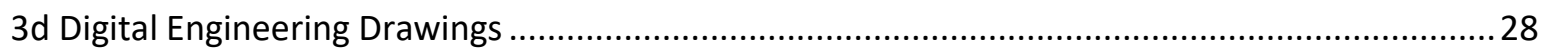

Born Digital Photographs and Video shared via Social Media or Uploaded to Cloud Services ........ 29

Completed investigations based on open source intelligence sources ..............................................30

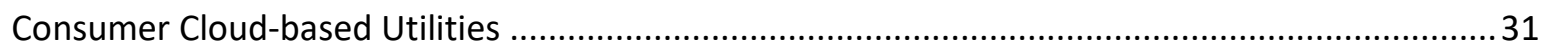

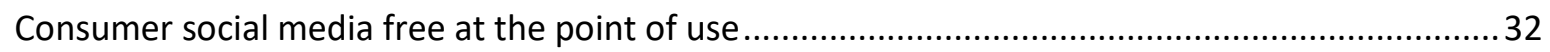

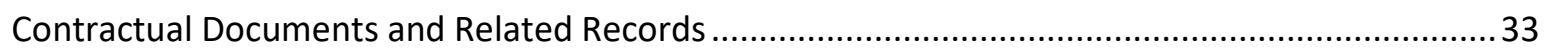

Corporate Records of Long Duration on Network Drives, Intranets and EDRMS ...........................34 


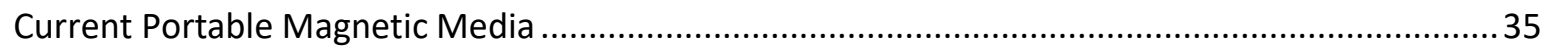

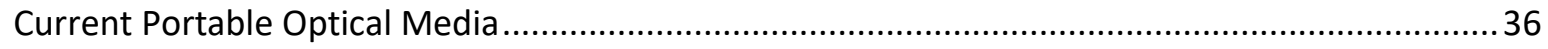

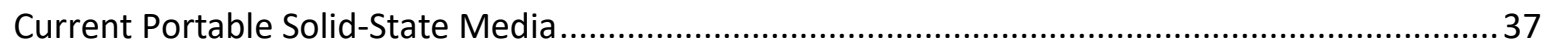

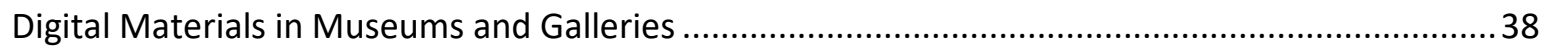

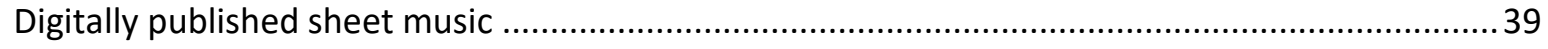

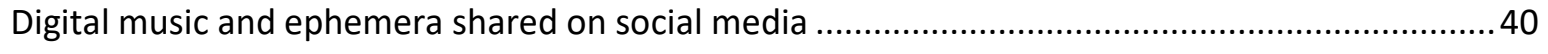

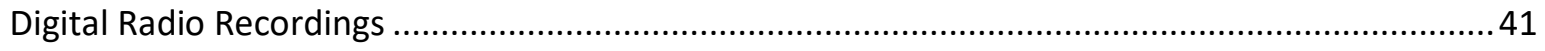

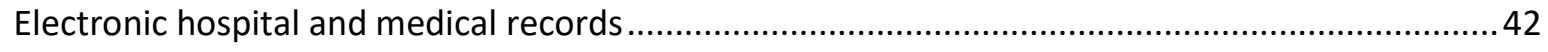

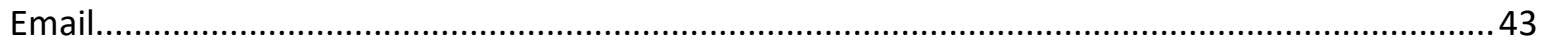

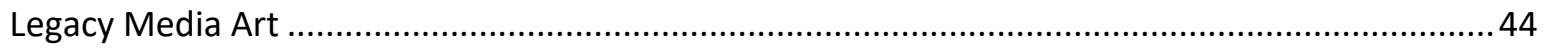

Massively Multiple Online Gaming Platforms and Experiences .................................................... 45

Master Digital Music and Sound Recordings .............................................................................. 46

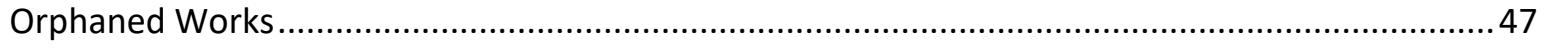

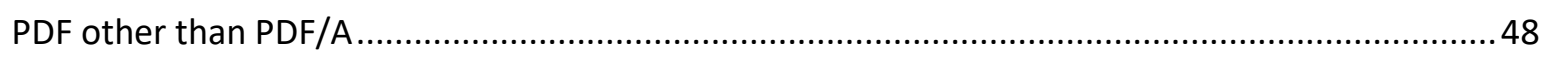

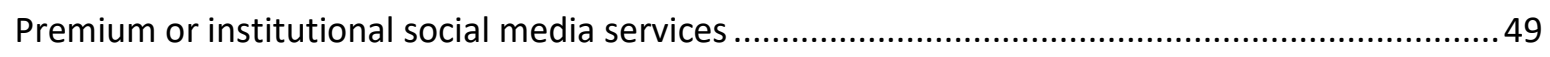

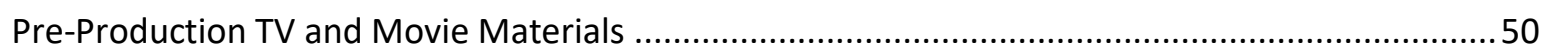

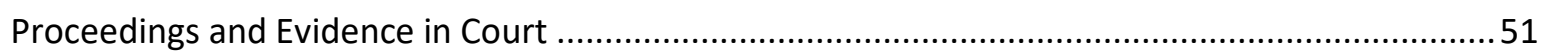

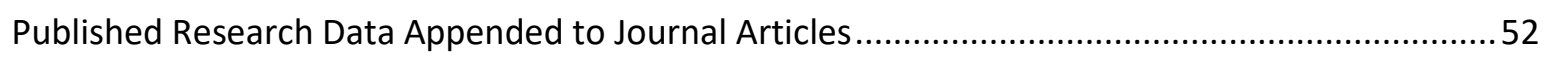

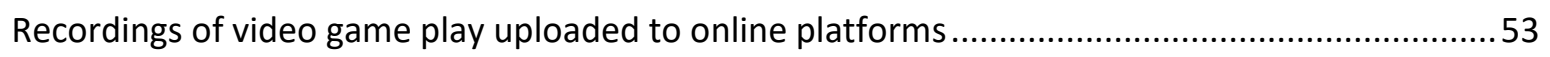

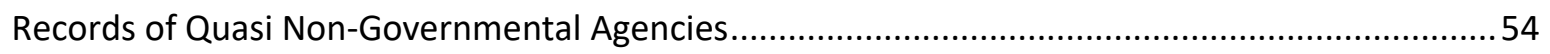

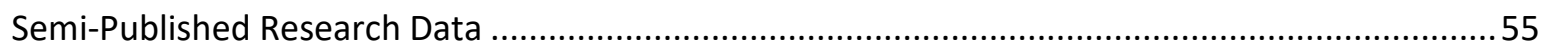

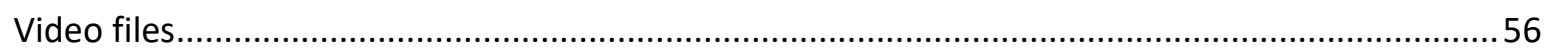

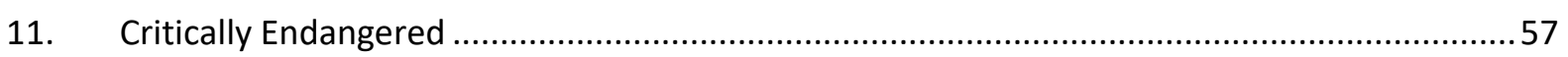

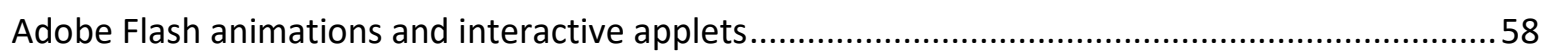

Born Digital Images Held Offline on Portable Storage Devices .......................................................59

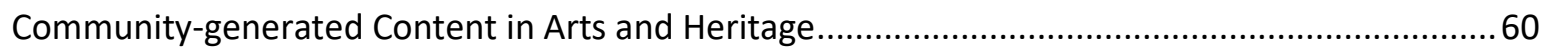

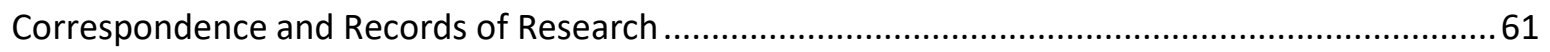

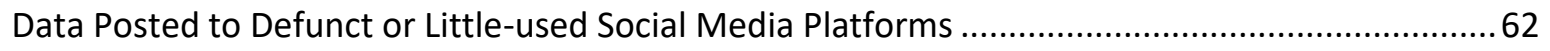

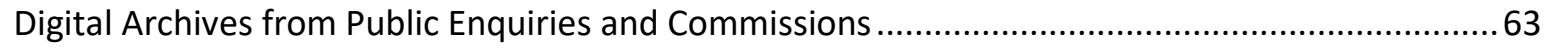

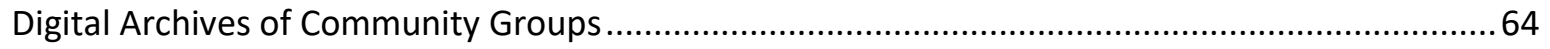

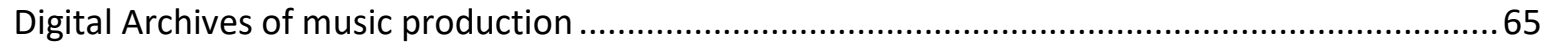

Digital Evidence and Records of Investigation Prior to Court........................................................6 66

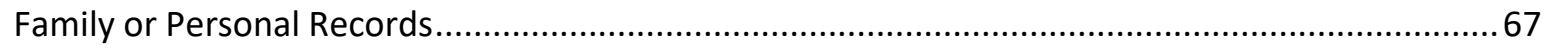

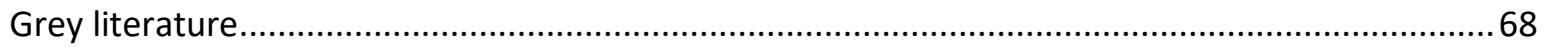

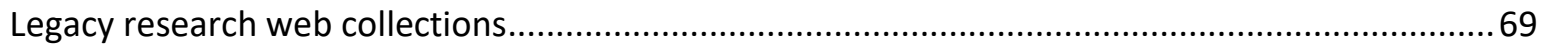

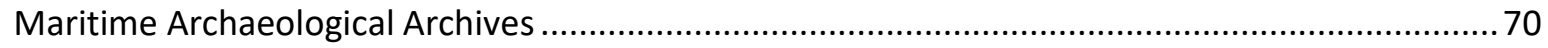


Digital Preservation Coalition

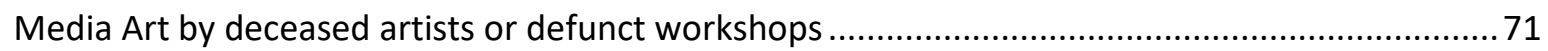

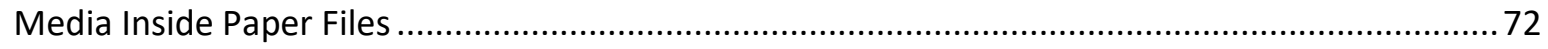

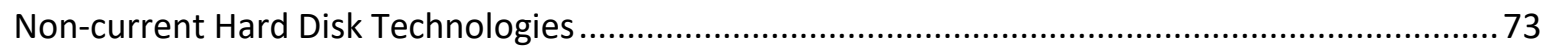

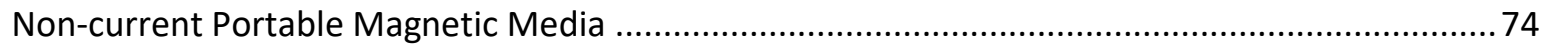

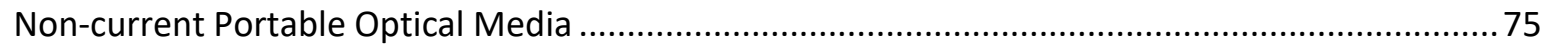

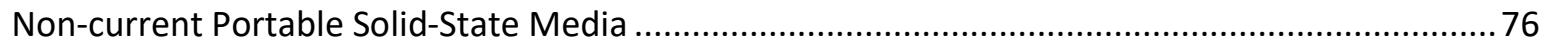

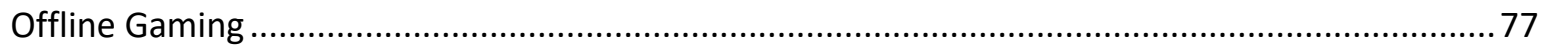

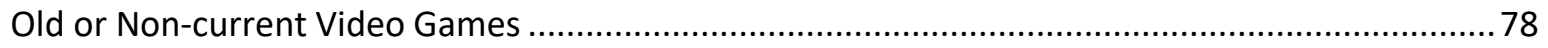

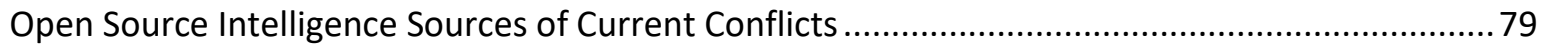

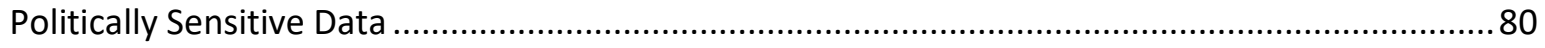

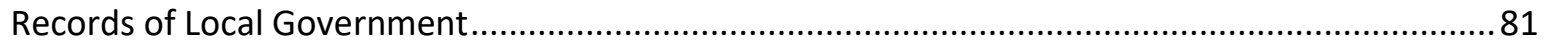

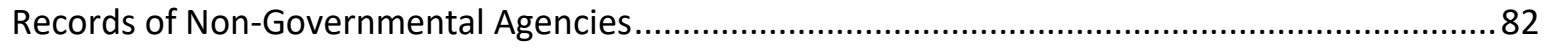

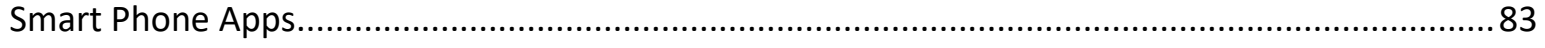

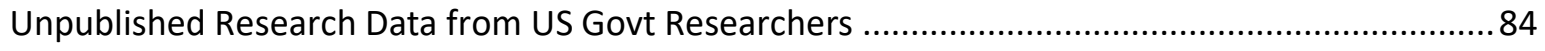

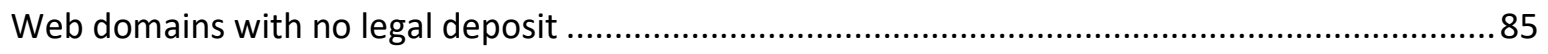

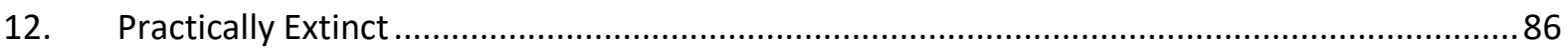

Legacy Interfaces and Services Offered Online by Major Companies ............................................. 87

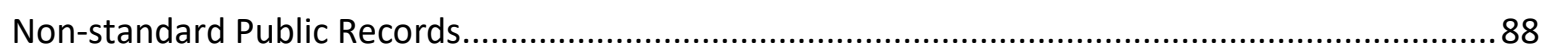

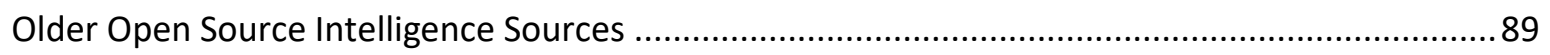

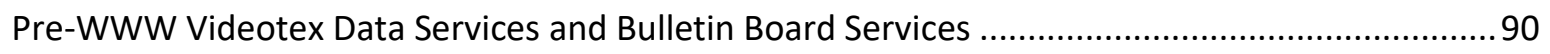

Pre-WWW ViewData and TeleText Services where no archival agency has captured and retained

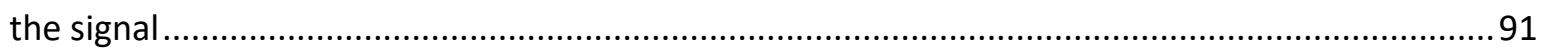

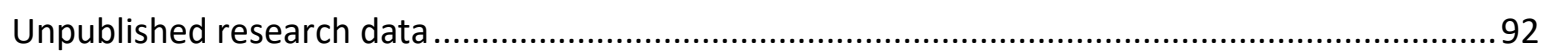




\section{About the Digital Preservation Coalition}

The Digital Preservation Coalition (DPC) exists to secure our digital legacy.

We enable our members to deliver resilient long-term access to digital content and services, helping them to derive enduring value from digital assets and raising awareness of the strategic, cultural and technological challenges they face. We achieve our aims through advocacy, community engagement, workforce development, capacity-building, good practice and good governance.

The DPC's work, including The BitList is shaped by our values. In all that it does, the DPC:

- maintains neutrality in respect to solutions, approaches, sectors and vendors;

- amplifies the needs and successes of our members;

- is open to all stakeholders;

- maintains sound stewardship of our shared resources;

- responds to the needs of members in the delivery of services;

- is authoritative, current and concise in all our publications and communications;

- is respectful, welcoming, inclusive and transparent in all our dealings.

Members and colleagues who engage with the DPC recognize these values in their experience of the DPC and may be asked to adopt them when working with us or interacting through us.

The scope of the DPC and its activities are defined in five ways:

- By our members: we invest considerable energy in framing a program that responds to members' needs. As the membership changes so this scope will change through time.

- By topic: we define digital preservation as the managed activities necessary to ensure continued access to digital materials for as long as necessary, including all the actions required to maintain access beyond the limits of media failure, technological obsolescence or community change. We engage in and with any and all of the people, tools, services, agencies and activities that aid this purpose.

- By sectors: we are a cross-sector, inter-disciplinary body, open to all who need to ensure continuing access to digital content, irrespective of purpose.

- By locale: digital preservation is a global challenge so the DPC makes a global offer. We welcome memberships, partnerships and collaborations with agencies and individuals around the world. Our origins are as a joint endeavour between agencies the UK and Ireland where the bulk of our members are still situated. But at the start of this planning period DPC is active in 10 countries and 3 continents. In the delivery of this strategic plan we will extend our global offer and we prepare our transition to a global foundation.

- By our values: we maintain our neutrality with respect to solutions, approaches and vendors because this protects the independence and value of our activities. But neutrality does not imply exclusion from meaningful engagement.

For more about the Digital Preservation Coalition, including how to join, see:

https://www.dpconline.org/ 


\section{Acknowledgements: The BitList Jury}

The DPC gratefully acknowledges the support of the worldwide digital preservation community in the compilation of The Bitlist.

In particular we are grateful to the expert panel who supported its creation and assessed the entries received in 2019:

- Matt Barr (University of Glasgow),

- Euan Cochrane (Yale University),

- Glenn Cumiskey (formerly British Museum now Royal Institute of British Architects),

- Bradley Daigle (AP Trust / NDSA),

- Kelly Forbes (Museums and Galleries Scotland),

- Abbie Grotke (Library of Congress),

- Edith Halvarsson (University of Oxford),

- Adam Harwood (University of Sussex),

- Stephen Haufek (UN),

- Lee Hibberd (National Library of Scotland),

- Eliot Higgins (Bellingcat),

- Matilda Knowler (HSBC),

- Faye Lemay (formerly Libraries and Archives Canada),

- Hervé L'Hours (UK Data Archive),

- Michelle Lindlar (TIB / nestor),

- Kirsty Lingstadt, University of Edinburgh

- Stephen McConnachie (British Film Institute),

- John McDonough (Dublin City University),

- Jaana Pinnick (British Geological Survey),

- Marcel Ras (DHN),

- Thorsten Ries (University of Ghent),

- Barbara Sierman (KB, now retired),

- Paul Stokes (Jisc),

- Bill Thompson (BBC)

- Jaye Weatherburn, University of Melbourne

- Sharon Webb, University of Sussex

and Jane Winters (School of Advanced Studies, University of London) who chaired the panel in 2019.

The 2020 Revision was completed by William Kilbride with Jen Mitcham and Paul Wheatley. 


\section{Director's Introduction to The BitList 2020}

The BitList 2020 is the second interim review of the list since initial publication in 2017.

Whereas The BitList was experimental in 2017 and 2018, the 2019 edition was considerably more robust in content and process. In part this is because it has established a small but definite following. Professionals in agencies around the world have reported their own use of The BitList to support advocacy and target resources to greater effect. That constitutes a success in relation to what we hoped to achieve in 2017, so in 2019 we moved from hopeful experiment to practical and continuing contribution back to the digital preservation community which have shaped and used it. In 2020 we have commented on recommendations suggesting the trends towards increased or diminished risk. There are no new entries nor have the substantive recommendations changed.

Considering the length of the report it is appropriate to offer a few highlights. This is especially important in $\mathbf{2 0 2 0}$ where the context for digital preservation - as for much else - has been dramatically disrupted by the Coronavirus Pandemic. Several aspects of the review deserve attention whether as inputs into the consideration or outcomes from the process.

Firstly, the main finding of the review is that, despite the heroic efforts of the digital preservation community, there is little or no discernible trend towards reduced risk in 2020; in fact the circumstances of the Covid19 Pandemic and the political and economic volatilities of the year have pushed seventeen items on the list towards greater risk. Only one entry is clearly trending towards reduced risk.

Trending towards increased risk:

- Born Digital Photographs and Video shared via Social Media or Uploaded to Cloud Services (p 29)

- Contractual Documents and Related Records (p 33)

- Corporate Records of Long Duration on Network Drives, Intranets and EDRMS ( $p$ 34)

- Digital Materials in Museums and Galleries ( $p$ 38)

- Electronic hospital and medical records ( $p$ 42)

- Legacy Media Art ( $p$ 44)

- Massively Multiple Online Gaming Platforms and Experiences ( $p$ 45)

- Adobe Flash animations and interactive applets ( $p 58$ )

- Community-generated Content in Arts and Heritage ( $p$ 60)

- Correspondence and Records of Research (p 61)

- Digital Archives of Community Groups ( $p$ 64)

- Grey Literature ( $p$ 68)

- Media Art by deceased artists or defunct workshops ( $p 71)$

- Politically Sensitive Data ( $p$ 80)

- Records of Local Government ( $p$ 81)

- Records of Non-Governmental Agencies ( $p$ 82)

- Non-standard Public Records ( $p 88$ )

Trending towards reduced risk:

- Pre-WWW ViewData and TeleText Services where no archival agency has captured and retained the signal ( $p$ 91) 
This outcome is based on consideration of the individual entries and their configuration, but it also includes a strategic assessment of digital preservation in 2020.

The year has seen increased risks of data loss in part because the digital preservation community is more precarious too. The economic impact of the pandemic as well as more localized political disruptions have introduced significant new levels of uncertainty across research, innovation, investment and procurement. Decisions have stalled, and in many contexts funds have been diverted to crisis management. A number of institutions have introduced early release schemes meaning established digital experts are retiring while others face redundancy. At the same time, short-term contracts may not be renewed as institutional budgets are squeezed or expenditure deferred. There are therefore rising challenges but less capacity.

Nonetheless, case studies of good practice continue to demonstrate what can be achieved when research and innovation are encouraged. New initiatives in the year, for example the DPC's EDRMS Preservation Task Force, are directly relevant to the preservation outcomes anticipated for items on the list. Digital preservation is challenging but tractable. In fact, the pandemic has only served to underline the material, urgent and ubiquitous importance of preservation. This is most obvious in the context of those many agencies capturing the record of the Pandemic, whether for scientific purposes or for cultural memory.

That importance also emerges from the long history of virology. How many times has it been stated that we live in unprecedented times? That's simply not true as anyone who survived the Spanish Flu epidemic of 1919 would testify. Pandemics are entirely precedented but they're also at the very limit of living memory and have been marginalized in public discourse and common experience. History records resilience and healing in the face of widespread suffering and that record has become suddenly more valuable. So, although there is a trend towards greater risk, 2020 shows that digital preservation is challenging, but tractable and essential.

In a number of cases it has been hard to assess the impact of the pandemic on the preservation outcomes for items on the list. For example, Family or Personal Records were assessed as Critically Endangered in 2019. It seems logical to suppose that the greater mortality of the pandemic would result in more archives being lost. A mortality rate of $1 \%$ is very high for a highly infectious disease but relatively small in absolute terms and arguably only a very marginal change in terms of the BitList. It also invites a counter-factual: if sudden awareness of mortality resulted in even $2 \%$ of personal or family archives being placed in better order than they were in 2019 then the trend in terms of preservation outcomes would be towards risk being reduced not increased. There is too little evidence to substantiate any firm finding.

Although the overall prognosis points to increased risk, it is also noteworthy that risks have not increased more. Despite the gloom only seventeen entries out of seventy-four exhibit a trend towards greater risk. One would have perhaps expected more. This is in part because of the considerable investment and interest in skills and advocacy in 2020, as well as significant targeted research. For example, the Novice to Know-how training course has been completed by over 1000 users at the time of writing, and a significant number of training and advocacy resources have been released and in a much wider variety of languages than hitherto.

The digital preservation community has also continued to grow in size and diversity through, and in some cases because of, the pandemic. The DPC is a barometer of both, having reached the milestone of 100 members in March, and added members in South Africa for the first time as well as a global financial services company. This points to a continued underlying dynamic of growth. 
The Global List of Digitally Endangered Species 2020

Participation on a truly global scale has been made possible by greater reliance on online communications.

Consequently, as the risks are increasing, so is the latent capability for preservation and collaboration in this field. And the BitList records risks, not outcomes so the simple identification of risks creates an opportunity to respond.

\section{William Kilbride}

Digital Preservation Coalition

$5^{\text {th }}$ November 2020 


\section{Interpreting and Using The BitList}

The BitList is first and foremost an advocacy tool. It describes a range of digital materials in varied organizational settings which, in the experience of the global digital preservation community, face distinct and imminent challenges. These challenges may be as much to do with accountability, policy or business process as about technological obsolescence or media decay. By identifying them, and by providing elementary recommendations about how the risks can be tackled, the DPC seeks to provide generic, impartial and international support to specific preservation actions and policies in any context.

Although all digital materials fall within the scope of the BitList, it is not a complete account of digital materials at risk: only those items which members of the community recognize as being at risk are included. Consequently, the fact that a data set is not listed should not be taken as evidence that it is not at risk: simply that the community which has compiled the list has not encountered any explicit risks or has no experience with these materials. Equally, the fact that an item has been identified as being at risk is some small proof of effort, however weak, to secure long-term viability. In most cases, entries on the list are broadly defined, summarizing significant variability in specific cases. Many items on the list overlap, amplifying or lessening the urgency for action as appropriate.

Each item on the list is given a short title and a longer description. It is described in general terms, then a series of examples are given. The examples are illustrative not exhaustive, and although they provide a bit more detail, in many cases they are also broadly defined which in turn have many instances and examples. The examples typically include specific submissions which were made in the open nomination process as well as examples which have arisen in discussion by the Jury.

Users of The BitList are encouraged to assess whether any digital object in their possession, or which they intend to create, or for which they have a current or imminent preservation responsibility, is a specific example of the item described and whether it aligns with one of the examples given.

Each item includes examples of Aggravating Conditions which amplify the risks a digital object faces, and Good Practice that would reduce the risk. These are also implied recommendations for addressing and reducing risks to be followed in the timescale indicated. In most cases a fuller assessment is also suggested. By implication the actions would arise from such an assessment are not likely to be trivial. The Jury has attempted to provide a simple assessment of how much work it would be to improve the situation as well as their perception of how wide the impact of loss would be. Finally, detailed comments from the Jury have been included where available.

The Jury has paid particular attention to the risk classification. Items were given a provisional ranking by a small first-sift jury which also identified those entries that required additional expert advice before they could be properly assessed. Recognized subject matter experts were then recruited to an expanded Jury which worked through each item in more detail. This process also saw the elimination of some entries, as well as merger of duplicate entries and disaggregation of compound entries into smaller groups accordingly. Every entry here is on the basis of a consensus decision, but in small number of cases the decision was unanimous. For the sake of transparency, The BitList reports those occasions where unanimity was achieved as this materially affects how recommendations are deployed.

The BitList 2020 has been compared to earlier editions of the and general comments have therefore been added about trends and activities that have had an impact on each item then. The overall classifications have not been changed though trends have been identified where these are clear. 
Recognizing that entries are very broadly defined, digital materials can be at more or less risk depending on local circumstances. There is greater risk and therefore greater urgency to act in the presence of aggravating conditions which can be delineated. So, while an entry may be classified as 'Vulnerable' in generic terms, any example of that entry may reasonably be described as 'Endangered' or 'Critically Endangered' in the presence of aggravating conditions. Conversely, in the presence of good practice, specific digital materials may move from 'Endangered' to 'Vulnerable' or 'Lower Risk'.

The BitList is designed to be collaborative, iterative and provisional. Thus, if readers are aware of significant digital collections that do not match up with any of the broad examples given but are at material risk, then they are encouraged to draw these to the attention of the Jury through the DPC's Head of Advocacy and Community Engagement. These will be reviewed in time for publication of the next scheduled update in November 2021. Where digital materials face an imminent extinction event before that, their evaluation may be accelerated and an addendum published to The Bitlist in order to provide the timely, impartial and expert advocacy that may be required. 


\section{Explanation of Classifications}

\section{Lower Risk}

Digital materials are listed as Lower Risk when they do not meet the requirements for other categories but where there is a distinct preservation requirement. Failure or removal of the preservation function would result in re-classification to one of the threatened categories.

\section{Vulnerable}

Digital materials are listed as Vulnerable when the technical challenges to preservation are modest but responsibility for care is poorly understood, or where the responsible agencies are not meeting preservation needs.

\section{Endangered}

Digital materials are listed Endangered when they face material technical challenges to preservation or responsibility for care is poorly understood, or where the responsible agencies are poorly equipped to meet preservation needs. This classification includes Vulnerable materials in the presence of aggravating conditions.

\section{Critically Endangered}

Digital materials are listed Critically Endangered when they face material technical challenges to preservation, there are no agencies responsible for them or those agencies are unwilling or unable to meet preservation needs. This classification includes Endangered materials in the presence of aggravating conditions.

\section{Practically Extinct}

Digital materials are listed as Practically Extinct when examples cannot be identified or are inaccessible by most practical means and methods. It does not assume that the material is lost, but rather that loss is imminent and immediate action is required to avoid loss. It includes material where recovery is possible in very small samples but is impractical or has not been demonstrated at scale. 


\section{Lower Risk}

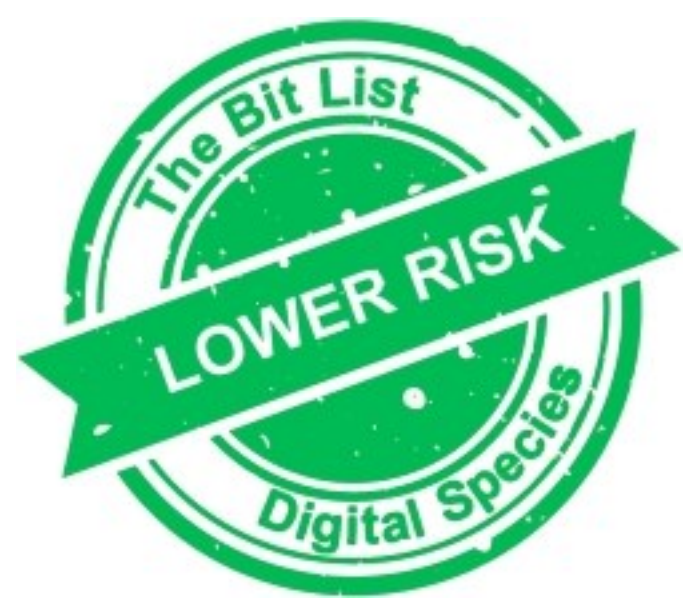

Digital materials are listed as Lower Risk when they do not meet the requirements for other categories but where there is a distinct preservation requirement. Failure or removal of the preservation function would result in reclassification to one of the threatened categories.

There are no entries in The BitList 2019 which meet this description. However, digital materials described as Vulnerable become Lower Risk where good practice is applied. Suggestions of good practice have been made. 


\section{Vulnerable}

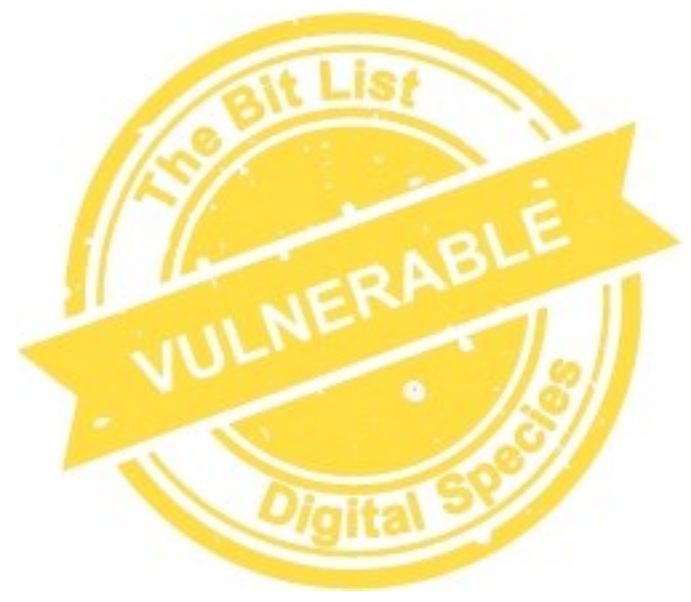

Digital materials are listed as Vulnerable when the technical challenges to preservation are modest but responsibility for care is poorly understood, or where the responsible agencies are not meeting preservation needs.

This classification would include Lower Risk materials in the presence of aggravating conditions; and endangered materials in the presence of good practice. 


\begin{tabular}{|c|c|c|}
\hline \multicolumn{2}{|l|}{ Cloud Storage } & \\
\hline \multicolumn{3}{|c|}{$\begin{array}{l}\text { Materials routinely copied or backed up to an independently } \\
\text { managed, off site data storage facility and able to be } \\
\text { restored under contractual terms }\end{array}$} \\
\hline Group: Storage & Trend in 2020: & Consensus Decision \\
\hline Added to List: 2019 & No Change & Previous category: New Entry \\
\hline $\begin{array}{l}\text { Imminence of Action } \\
\text { Action is recommended } \\
\text { within three years, detailed } \\
\text { assessment within one year. }\end{array}$ & $\begin{array}{l}\text { Significance of Loss } \\
\text { The loss of tools, data or } \\
\text { services within this group } \\
\text { would impact on many } \\
\text { people and sectors }\end{array}$ & $\begin{array}{l}\text { Effort to Preserve } \\
\text { It would require a small effort to } \\
\text { preserve materials in this group, } \\
\text { requiring the application of proven } \\
\text { tools and techniques. }\end{array}$ \\
\hline \multicolumn{3}{|c|}{$\begin{array}{l}\text { Examples } \\
\text { Remote network storage provided by a third-party service under contract, such as DropBox, } \\
\text { Amazon, Microsoft Azure, Dell EMC, Google Cloud Platform, Google Drive, IBM, Intel, Rackspace, } \\
\text { Iron Mountain, SAP and others }\end{array}$} \\
\hline \multicolumn{3}{|c|}{$\begin{array}{l}\text { 'Endangered’ in the Presence of Aggravating Conditions } \\
\text { Encryption; lack of routine maintenance; lack of storage replication; over-dependence on single } \\
\text { supplier; insufficient documentation; lack of local alternative; political or commercial instability; } \\
\text { overly aggressive compression; poor information security; lack of transparent integrity-checking; } \\
\text { lack of strategic investment; lack of migration plan; lack of exit strategy; unenforceable penalties; } \\
\text { unstable pricing; unpredictable removal costs }\end{array}$} \\
\hline \multicolumn{3}{|c|}{$\begin{array}{l}\text { Backup to different technology; backup to diverse locations; documentation of assets; integrity } \\
\text { checking; preservation planning; export functionality; resilient to hacking; version control; } \\
\text { resilient funding; technology watch; enforceable contract; disaster planning and documentation, } \\
\text { stable pricing; budgeted removal costs. }\end{array}$} \\
\hline \multicolumn{3}{|c|}{$\begin{array}{l}\text { The judges introduced this entry to ensure that the range of media storage is properly assessed } \\
\text { and presented. }\end{array}$} \\
\hline \multicolumn{3}{|c|}{ Additional Jury Comments } \\
\hline \multicolumn{3}{|c|}{$\begin{array}{l}\text { The history of digital preservation suggests that the risk of vendors going out of business or } \\
\text { shutting down services is the key issue here, over and above any specific technical solutions or } \\
\text { risks. }\end{array}$} \\
\hline \multicolumn{3}{|l|}{ See also: } \\
\hline $\begin{array}{l}\text { Digital Preservation Coalitior } \\
\text { online at } h t t p s: / / \text { dpconline.c }\end{array}$ & $\begin{array}{l}\text { 2016) 'Storage' in Digital Pr } \\
\text { /handbook/organisational- }\end{array}$ & $\begin{array}{l}\text { /ation Handbook (Second Edition), } \\
\text { ities/storage }\end{array}$ \\
\hline
\end{tabular}




\begin{tabular}{|c|c|c|}
\hline \multicolumn{2}{|c|}{$\begin{array}{l}\text { Content on cloud video services produced by } \\
\text { the service provider }\end{array}$} & \\
\hline \multicolumn{2}{|c|}{$\begin{array}{l}\text { Video materials - films and television programs - that are } \\
\text { produced by companies that maintain their own distribution } \\
\text { platforms and are exclusively available through these } \\
\text { platforms. }\end{array}$} & \\
\hline Group: Sound and Vision & Trend in 2020: & Consensus Decision \\
\hline Added to List: 2019 & No Change & Previous category: New Entry \\
\hline $\begin{array}{l}\text { Imminence of Action } \\
\text { Action is recommended } \\
\text { within three years, detailed } \\
\text { assessment within one year. }\end{array}$ & $\begin{array}{l}\text { Significance of Loss } \\
\text { The loss of tools, data or } \\
\text { services within this group } \\
\text { would impact on people and } \\
\text { sectors around the world. }\end{array}$ & $\begin{array}{l}\text { Effort to Preserve } \\
\text { It would require a major effort to } \\
\text { preserve materials in this group, } \\
\text { including the development of new } \\
\text { tools or techniques. }\end{array}$ \\
\hline \multicolumn{3}{|l|}{ Examples } \\
\hline \multicolumn{3}{|c|}{$\begin{array}{l}\text { Lack of corporate preservation planning; lack of preservation capability; conflating backup with } \\
\text { preservation; loss of original recordings; lack of preservation voice at executive level; poor } \\
\text { planning and roadmap for infrastructure; slapdash procurement or migration to new systems; } \\
\text { mergers and acquisitions; profusion of corporate systems; complex intellectual property rights; } \\
\text { single point of failure; technical protection measures that inhibit reasonable preservation actions. }\end{array}$} \\
\hline \multicolumn{3}{|c|}{$\begin{array}{l}\text { 'Lower Risk' in the Presence of Good Practice } \\
\text { backup and documentation; use of open formats and open source software; data management } \\
\text { planning; licencing that enables preservation; corporate preservation capability; resilient to } \\
\text { hacking; authenticity and integrity managed; recognition of preservation functions at executive } \\
\text { level; technology watch; preservation audits; participation in preservation community. }\end{array}$} \\
\hline \multicolumn{3}{|c|}{$\begin{array}{l}\text { This is a new entry from the open nomination, representing collections that are highly significant } \\
\text { in cultural and social terms. It was adopted as the Jury was unclear whether content could be } \\
\text { played outside of the producers' publication platform. That introduces technical dependencies } \\
\text { between content and software which are amplified by rights management. }\end{array}$} \\
\hline \multicolumn{3}{|c|}{$\begin{array}{l}\text { Additional Jury Comments } \\
\text { This entry has five aspects. } 1 \text {. It falls outside of the scope of traditional regulatory frameworks } \\
\text { and archiving has not yet been included in any legislative framework, unlike broadcast tv where } \\
\text { there is a designated archive in most developed nations. 2. As a result, the collecting and } \\
\text { preservation of the content from the online platforms is underdeveloped, and the content } \\
\text { remains unavailable in public archives. 3. These risks are mitigated by the fact that the } \\
\text { commercial archives are technologically advanced, with mature digital ecosystems and skills, and } \\
\text { much of the content has a 'long tail' business model and as commercial products these have } \\
\text { value, so preservation incentives are clear. } 4 \text {. However these are often stored at scale on LTO taps } \\
\text { and so specific issues arise with the obsolescence of LTO tape technologies for the broadcast } \\
\text { sector. } 5 \text {. Nonetheless, issues remain around archiving the rushes, and other relevant assets } \\
\text { which may not be valued by the production company. }\end{array}$} \\
\hline
\end{tabular}




\begin{tabular}{|c|c|c|}
\hline \multicolumn{2}{|c|}{ Current Hard Disk Technologies } & \\
\hline \multicolumn{2}{|c|}{$\begin{array}{l}\text { Materials saved to storage devices with a variety of } \\
\text { underlying magnetic or solid-state (flash) technologies that } \\
\text { are hardwired into a computer still under warranty or } \\
\text { supported: typically hard disks that are less than five years } \\
\text { old. }\end{array}$} & \\
\hline Group: Storage & Trend in 2020: & Consensus Decision \\
\hline Added to List: 2019 & No Change & Previous category: New Entry \\
\hline $\begin{array}{l}\text { Imminence of Action } \\
\text { Action is recommended } \\
\text { within three years, detailed } \\
\text { assessment within one year. }\end{array}$ & $\begin{array}{l}\text { Significance of Loss } \\
\text { The loss of tools, data or } \\
\text { services within this group } \\
\text { would impact on many } \\
\text { people and sectors. }\end{array}$ & $\begin{array}{l}\text { Effort to Preserve } \\
\text { It would require a small effort to } \\
\text { preserve materials in this group, } \\
\text { requiring the application of proven } \\
\text { tools and techniques. }\end{array}$ \\
\hline \multicolumn{3}{|c|}{$\begin{array}{l}\text { Examples } \\
\text { Direct Attached Storage (DAS) such as Magnetic or solid-state drives integrated into individual } \\
\text { laptop or workstations and into smaller scale storage facilities. }\end{array}$} \\
\hline \multicolumn{3}{|c|}{$\begin{array}{l}\text { Encryption; poor handling; poor storage; lack of consistent replication; failure of external } \\
\text { (dependencies eg suppliers, security); political or commercial interference; failure of internal } \\
\text { dependencies (e.g. power supply, disk controller); overly aggressive compression; poor } \\
\text { information security; lack of integrity-checking; lack of strategic investment; lack of warranty; } \\
\text { unenforceable warranty; encryption. }\end{array}$} \\
\hline \multicolumn{3}{|c|}{$\begin{array}{l}\text { Backup to different technology; backup to diverse locations; documentation of assets; integrity } \\
\text { checking; preservation planning; refreshment planning; export functionality; resilient to hacking; } \\
\text { selection and appraisal criteria; version control; resilient funding; technology watch; enforceable } \\
\text { warranty; disaster planning. }\end{array}$} \\
\hline \multicolumn{3}{|c|}{$\begin{array}{l}\text { The judges introduced this entry to ensure that the range of media storage is properly assessed } \\
\text { and presented. }\end{array}$} \\
\hline $\begin{array}{l}\text { Additional Jury Comments } \\
\text { See also: } \\
\text { Digital Preservation Coalition } \\
\text { online at https://dpconline.o }\end{array}$ & 016) 'Storage' in Digital Pr & $\begin{array}{l}\text { tion Handbook (Second Edition), } \\
\text { ties/storage }\end{array}$ \\
\hline
\end{tabular}




\begin{tabular}{|c|c|c|}
\hline \multicolumn{2}{|c|}{$\begin{array}{l}\text { Digital recordings published via cloud-based } \\
\text { music sharing platforms }\end{array}$} & \\
\hline \multicolumn{2}{|c|}{$\begin{array}{l}\text { Music licensed and playable through corporate platforms } \\
\text { protected by rights management and subscription revenues } \\
\text { and presented as compressed single-track recordings. }\end{array}$} & \\
\hline Group & & onsensus Decision \\
\hline Addec & & revious category: New Entry \\
\hline $\begin{array}{l}\text { Imminence of Action } \\
\text { Action is recommended } \\
\text { within three years, detailed } \\
\text { assessment within one year. }\end{array}$ & $\begin{array}{l}\text { data or } \\
\text { s group } \\
\text { eople and } \\
\text { world. }\end{array}$ & $\begin{array}{l}\text { ort to } \\
\text { roup, } \\
\text { of new }\end{array}$ \\
\hline \multicolumn{3}{|c|}{$\begin{array}{l}\text { Examples } \\
\text { Spotify, iTunes, Bandcamp, SoundCloud }\end{array}$} \\
\hline \multicolumn{3}{|c|}{$\begin{array}{l}\text { 'Endangered' in the Presence of Aggravating Conditions } \\
\text { Lack of preservation capability within corporate systems; conflating backup with preservation; } \\
\text { loss of original multi-track recordings; lack of preservation voice at executive level; poor planning } \\
\text { and roadmap for corporate infrastructure; slapdash procurement or migration to new systems; } \\
\text { mergers and acquisitions; profusion of corporate systems; complex intellectual property rights; } \\
\text { single point of failure; technical protection measures that inhibit preservation actions; encryption. }\end{array}$} \\
\hline \multicolumn{3}{|c|}{$\begin{array}{l}\text { 'Lower Risk' in the Presence of Good Practice } \\
\text { Strong backup and documentation; use of open formats and open source software; data } \\
\text { management planning for preservation; licencing that enables preservation; corporate } \\
\text { preservation capability; resilient to hacking; authenticity and integrity managed; recognition of } \\
\text { preservation functions at executive level; technology watch; regular preservation audits; } \\
\text { accreditation and participation in professional preservation community. }\end{array}$} \\
\hline \multicolumn{3}{|c|}{$\begin{array}{l}2019 \text { Review } \\
\text { The } 2017 \text { BitList included an entry for Digital Music Production and Sharing which included this } \\
\text { entry. In } 2019 \text { the Jury decided to split this initial nomination into four, recognising the different } \\
\text { challenges faced. This entry is particularly concerned with the music industry at scale and the } \\
\text { services that connect the vast majority of artists to their audiences. These are typically large and } \\
\text { well-funded, and typically recognise the value of the content they publish. But this is not without } \\
\text { risks and it is perhaps surprising that the music industry does not yet have any equivalent to the } \\
\text { non-print legal deposit regime that applies to other types of publication, including sheet music in } \\
\text { some jurisdictions. }\end{array}$} \\
\hline \multicolumn{3}{|c|}{$\begin{array}{l}\text { Additional Jury Comments } \\
\text { The preservation of recorded music is one of our generations most important jobs but it's unclear } \\
\text { where responsibility lies. There are commercial incentives to do so but there are also incentives to } \\
\text { reduce costs. National collecting organizations may need to develop a role to address this. Whilst } \\
\text { public archives are permitted to keep this material in some jurisdictions they typically do not have } \\
\text { the resources to do so. Consequently, there is an expectation that rights holders will maintain } \\
\text { their own archival copies which they may not be able to do. }\end{array}$} \\
\hline
\end{tabular}




\begin{tabular}{|c|c|c|}
\hline \multicolumn{2}{|c|}{ Geomagnetic Data and Software } & \\
\hline \multicolumn{2}{|c|}{$\begin{array}{l}\text { Data, software and supporting paradata relating to Earth's } \\
\text { magnetic field and Earth-Sun environment, including current } \\
\text { declination, geomagnetic field surveys and observations, } \\
\text { field models and magnetic indices, and data from } \\
\text { geomagnetic observatories. }\end{array}$} & \\
\hline Group: Research Outputs & Trend in 2020: & Unanimous Decision \\
\hline Addec & No & revious category: Of Concern \\
\hline $\begin{array}{l}\text { Imminence of Action } \\
\text { Action is recommended } \\
\text { within three years, detailed } \\
\text { assessment within one year. }\end{array}$ & $\begin{array}{l}\text { Significance of Loss } \\
\text { The loss of tools, data or } \\
\text { services within this group } \\
\text { would impact on people and } \\
\text { sectors around the world. }\end{array}$ & $\begin{array}{l}\text { Effort to Preserve } \\
\text { It would require a major effort to } \\
\text { preserve materials in this group, } \\
\text { including the development of new } \\
\text { tools or techniques. }\end{array}$ \\
\hline \multicolumn{3}{|c|}{$\begin{array}{l}\text { Examples } \\
\text { Outputs from geomagnetic scanning and measurement sensors both terrestrial and satellite- } \\
\text { based, as well as supporting calibration and reference data and software to enable assembly and } \\
\text { rectification to co-ordinate systems }\end{array}$} \\
\hline \multicolumn{3}{|c|}{$\begin{array}{l}\text { ‘Endangered' in the Presence of Aggravating Conditions } \\
\text { Bespoke or undocumented software; undocumented data cleaning; disassociation with } \\
\text { documenting, especially instrument calibration data; Lack of conformance or validation against } \\
\text { standards; lack of preservation commitment or planning; no identified repository or lack of } \\
\text { capability in repository; lack of storage replication; political or commercial interference; loss of } \\
\text { version control; poorly managed intellectual property rights; poor metadata; loss of authenticity. }\end{array}$} \\
\hline \multicolumn{3}{|c|}{$\begin{array}{l}\text { Lower Risk in the Presence of Good Practice } \\
\text { backup and documentation; use of open formats and open source software; data management } \\
\text { planning before fieldwork; licencing that enables preservation; preservation capability in } \\
\text { designated repository; resilient to hacking; selection and appraisal criteria; version control; } \\
\text { authenticity; resilient funding and recognition of value; technology watch. }\end{array}$} \\
\hline \multicolumn{3}{|c|}{$\begin{array}{l}2019 \text { Review } \\
\text { This entry was introduced in } 2017 \text { but was outside the competence of the judges to assess at that } \\
\text { time. It was scheduled to be assessed in } 2019 \text { and additional expertise was invited to the panel to } \\
\text { support this assessment: but it was also independently introduced through the open nomination } \\
\text { process again in 2019. It is presented as an example of research data, though noting the } \\
\text { competences of agencies involved in preserving geo-magnetic data and software it has been } \\
\text { classified accordingly. }\end{array}$} \\
\hline \multicolumn{3}{|c|}{$\begin{array}{l}\text { Additional Jury Comments } \\
\text { Institutions that collect and manage geomagnetic data should strongly consider an assessment } \\
\text { against the Core Trust Seal which now incorporates many of the characteristics previously } \\
\text { measured by the World Data System. Researchers intending to create data should examine data } \\
\text { management planning tools; and researcher intending to deposit data should assess whether } \\
\text { their chosen repository meets the Core Trust Seal Requirements. }\end{array}$} \\
\hline
\end{tabular}




\begin{tabular}{|c|c|c|}
\hline \multicolumn{2}{|l|}{ Local Network Storage } & \\
\hline \multicolumn{2}{|c|}{$\begin{array}{l}\text { Materials routinely copied or backed up to locally managed } \\
\text { data storage facility and able to be restored under } \\
\text { institutional service arrangements }\end{array}$} & \\
\hline Group: Storage & Trend in 2020: & Consensus Decision \\
\hline Added to List: 2019 & No Change & Previous category: New Entry \\
\hline $\begin{array}{l}\text { Imminence of Action } \\
\text { Action is recommended } \\
\text { within three years, detailed } \\
\text { assessment within one year. }\end{array}$ & $\begin{array}{l}\text { Significance of Loss } \\
\text { The loss of tools, data or } \\
\text { services within this group } \\
\text { would impact on many } \\
\text { people and sectors. }\end{array}$ & $\begin{array}{l}\text { Effort to Preserve } \\
\text { It would require a small effort to } \\
\text { preserve materials in this group, } \\
\text { requiring the application of proven } \\
\text { tools and techniques. }\end{array}$ \\
\hline \multicolumn{3}{|c|}{$\begin{array}{l}\text { Examples } \\
\text { Institutional or departmental network storage and institutional data centres based on } \\
\text { technologies such as (NAS) Network Attached Storage, (RAID) Redundant Array of Independent } \\
\text { Disks, (SAN) Storage Area Networks, JBOD (Just a bunch of disks), SPAN and related }\end{array}$} \\
\hline \multicolumn{3}{|c|}{$\begin{array}{l}\text { Encryption; lack of routine maintenance; lack of storage replication; over-dependence on single } \\
\text { supplier, technology or technician; insufficient documentation; single point of failure; political or } \\
\text { commercial interference; failure of dependencies (eg power supply, controller software); overly } \\
\text { aggressive compression; poor information security; lack of integrity-checking; lack of strategic } \\
\text { investment; lack of warranty; unenforceable warranty, encryption. }\end{array}$} \\
\hline \multicolumn{3}{|c|}{$\begin{array}{l}\text { Backup to different technology; backup to diverse locations; documentation of assets; integrity } \\
\text { checking; preservation planning; refreshment planning; export functionality; resilient to hacking; } \\
\text { selection and appraisal criteria; version control; resilient funding; technology watch; enforceable } \\
\text { warranty; disaster planning and documentation. }\end{array}$} \\
\hline \multicolumn{3}{|c|}{$\begin{array}{l}\text { The judges introduced this entry to ensure that the range of media storage is properly assessed } \\
\text { and presented. }\end{array}$} \\
\hline \multicolumn{3}{|c|}{$\begin{array}{l}\text { Additional Jury Comments } \\
\text { See also: } \\
\text { Digital Preservation Coalition (2016) 'Storage' in Digital Preservation Handbook (Second Edition), } \\
\text { online at https://dpconline.org/handbook/organisational-activities/storage }\end{array}$} \\
\hline
\end{tabular}




\begin{tabular}{|c|c|c|}
\hline \multicolumn{2}{|l|}{ PDF/A } & \\
\hline \multicolumn{2}{|c|}{$\begin{array}{l}\text { Materials contained within PDF/A, a format derived from } \\
\text { the PDF } 1.4 \text { variant but with additional requirements that } \\
\text { reduce external dependencies. Includes more recent } \\
\text { variants (PDF/A2 and PDF/A3) }\end{array}$} & \\
\hline Group: File Formats & Trend in 2020: & Consensus Decision \\
\hline Added to List: 2017 & No Change & Previous category: Of Concern \\
\hline $\begin{array}{l}\text { Imminence of Action } \\
\text { Action is recommended } \\
\text { within five years, detailed } \\
\text { assessment within three } \\
\text { years }\end{array}$ & $\begin{array}{l}\text { Significance of Loss } \\
\text { The loss of tools, data or } \\
\text { services within this group } \\
\text { would impact on people and } \\
\text { sectors around the world. }\end{array}$ & $\begin{array}{l}\text { Effort to Preserve } \\
\text { It would require a small effort to } \\
\text { preserve materials in this group, } \\
\text { requiring the application of proven } \\
\text { tools and techniques. }\end{array}$ \\
\hline \multicolumn{3}{|c|}{$\begin{array}{l}\text { Examples } \\
\text { Documents stored offline, or online in repositories or EDRMS including as reports, agenda, } \\
\text { minutes, correspondence, contracts, essays, articles, or research papers. }\end{array}$} \\
\hline \multicolumn{3}{|c|}{$\begin{array}{l}\text { 'Endangered' in the Presence of Aggravating Conditions } \\
\text { Lack of conformance or validation; Lack of preservation commitment or planning; Lack of storage } \\
\text { replication; Poor management of data protection or intellectual property rights; Political or } \\
\text { commercial interference; loss of version control; use beyond the design capability of the standard; } \\
\text { complacency; poor metadata; disassociation from context; loss of authenticity; encryption. }\end{array}$} \\
\hline \multicolumn{3}{|c|}{$\begin{array}{l}\text { 'Lower Risk' in the Presence of Good Practice } \\
\text { Backup and documentation of media assets; validation on creation; part of preservation plan; } \\
\text { export functionality; licencing enables preservation; preservation capability in repository or } \\
\text { EDRMS service; resilient to hacking; selection and appraisal criteria; version control; authenticity; } \\
\text { resilient funding and recognition of value; technology watch }\end{array}$} \\
\hline \multicolumn{3}{|c|}{$\begin{array}{l}2019 \text { Review } \\
\text { The judges have introduced this entry as a subset of a previous entry for 'PDF', emphasizing the } \\
\text { different threats faced by the two main types of PDF. PDF/A explicitly reduces dependencies and } \\
\text { thus curtails preservation risks for certain types of content. This alone is not sufficient to ensure } \\
\text { preservation and users are warned against complacency. PDF/A has sometimes been } \\
\text { misunderstood or misrepresented as a generic solution to all digital preservation requirements, } \\
\text { whereas in the eyes of the judges it can only offer a preservation solution when embedded within } \\
\text { a wider preservation infrastructure. }\end{array}$} \\
\hline \multicolumn{3}{|c|}{$\begin{array}{l}\text { Vulnerability also depends on if the PDF file conforms to the specific PDF/A standard or not. This is } \\
\text { caused by a combination of 1) not conforming to the standard and 2) collection managers } \\
\text { assuming that the file is resilient simply because it purports to be a PDF/A. This risk is less with } \\
\text { format and more with the understanding and experience in data management. Moreover, } \\
\text { materials embedded in or attached to PDF/A-2 and PDF/A-3 may be at risk. }\end{array}$} \\
\hline $\begin{array}{l}\text { See also: } \\
\text { - Fanning, B (2017) } \\
\text { 17-01 online at htt }\end{array}$ & $\begin{array}{l}\text { erving with PF/A (Second Editi } \\
\text { dx.doi.org/10.7207/twr17-01 }\end{array}$ & ), DPC Technology Watch Report \\
\hline
\end{tabular}




\begin{tabular}{|c|c|c|}
\hline \multicolumn{2}{|c|}{ Pension, Mortgage and Insurance Records } & \\
\hline \multicolumn{2}{|c|}{$\begin{array}{l}\text { Records of transactions for long-lived financial products and } \\
\text { services contracted between individuals and corporations. } \\
\text { These records typically contain or depend on significant } \\
\text { amounts of personal information and outlast the } \\
\text { infrastructure on which they were created. }\end{array}$} & \\
\hline Group: Sensitive Data & Trend in 2020: & onsensus Decision \\
\hline Addec & & Previous category: Of Concern \\
\hline $\begin{array}{l}\text { Imminence of Action } \\
\text { Action is recommended } \\
\text { within three years, detailed } \\
\text { assessment within one year. }\end{array}$ & $\begin{array}{l}\text { Significance of Loss } \\
\text { The loss of tools, data or } \\
\text { services within this group } \\
\text { would impact on many } \\
\text { people and sectors }\end{array}$ & $\begin{array}{l}\text { Effort to Preserve } \\
\text { It would require a small effort to } \\
\text { preserve materials in this group, } \\
\text { with the deployment of proven } \\
\text { tools or techniques. }\end{array}$ \\
\hline \multicolumn{3}{|c|}{$\begin{array}{l}\text { Examples } \\
\text { Applications, correspondence and ancillary records relating to pensions, mortgages and } \\
\text { insurances and other contracts of long duration. This includes corporate databases, email, web } \\
\text { archives and EDRMS and may require some co-ordination of paper, microfiche, born digital and } \\
\text { digitized records. Records will likely include the scope and duration of the contract as well as any } \\
\text { agreed changes during the lifetime of the product. It may also include evidence of misselling or } \\
\text { other sharp practice which only becomes apparent after the fact. This entry pertains to the } \\
\text { corporate records rather than personal records. }\end{array}$} \\
\hline \multicolumn{3}{|c|}{$\begin{array}{l}\text { 'Endangered' in the Presence of Aggravating Conditions } \\
\text { Lack of corporate preservation planning; lack of preservation within procurement of corporate } \\
\text { systems; companies conflating backup with preservation; loss of integrity and authenticity; loss of } \\
\text { context and connections to provide meaning; lack of preservation capability within agencies; lack } \\
\text { of preservation voice at executive level; poor planning and roadmap for corporate infrastructure; } \\
\text { proliferation of legacy systems; slapdash procurement or migration of new systems; mergers and } \\
\text { acquisitions leading to confusion of corporate systems; lack of compliance, audit or accountability } \\
\text { at operational levels; encryption. }\end{array}$} \\
\hline \multicolumn{3}{|c|}{$\begin{array}{l}\text { 'Lower Risk' in the Presence of Good Practice } \\
\text { backup and documentation; use of open formats and open source software; considered data } \\
\text { management planning; licencing that enables preservation; preservation capability in designated } \\
\text { repository; resilient to hacking; selection and appraisal in place; authenticity and integrity of } \\
\text { records managed; resilient funding and recognition at executive level; technology watch; regular } \\
\text { preservation audits; accreditation and participation in professional preservation community. }\end{array}$} \\
\hline \multicolumn{3}{|c|}{$\begin{array}{l}2019 \text { Review } \\
\text { This entry was introduced in } 2017 \text { but was outside the competence of the judges to assess at that } \\
\text { time. It was assessed in } 2019 \text { with additional expertise invited to the panel to support this } \\
\text { assessment. }\end{array}$} \\
\hline \multicolumn{3}{|c|}{ Additional Jury Comments } \\
\hline
\end{tabular}




\begin{tabular}{|c|c|c|}
\hline \multicolumn{2}{|c|}{ Published Research Papers } & \\
\hline \multicolumn{2}{|c|}{$\begin{array}{l}\text { Completed research papers published in serials, } \\
\text { monographs or theses which fall under specific collecting } \\
\text { policies of research libraries or archives and are managed } \\
\text { through dedicated repository infrastructures. }\end{array}$} & \\
\hline Group: Research Outputs & Trend in 2020: & Strong Consensus Decision \\
\hline Added to List: 2017 & No Change & Previous category: Endangered \\
\hline $\begin{array}{l}\text { Imminence of Action } \\
\text { Action is recommended } \\
\text { within five years, detailed } \\
\text { assessment within three } \\
\text { years }\end{array}$ & $\begin{array}{l}\text { Significance of Loss } \\
\text { The loss of tools, data or } \\
\text { services within this group } \\
\text { would impact on people and } \\
\text { sectors around the world. }\end{array}$ & $\begin{array}{l}\text { Effort to Preserve } \\
\text { It would require a small effort to } \\
\text { preserve materials in this group, } \\
\text { with the deployment of proven } \\
\text { tools or techniques. }\end{array}$ \\
\hline \multicolumn{3}{|c|}{$\begin{array}{l}\text { Examples } \\
\text { Scholarly E-Books, Electronic Journals, E-theses, Electronic Monographs. }\end{array}$} \\
\hline \multicolumn{3}{|c|}{$\begin{array}{l}\text { 'Endangered' in the Presence of Aggravating Conditions } \\
\text { Lack of documentation; lack of clarity with respect to intellectual property; embedded complex } \\
\text { objects; unstable funding for repository; lack of strategic investment; complex external } \\
\text { dependencies; lack of persistent identifiers; bespoke formats; lack of legal deposit mandate. }\end{array}$} \\
\hline \multicolumn{3}{|c|}{$\begin{array}{l}\text { 'Lower Risk' in the Presence of Good Practice } \\
\text { Strong documentation including intellectual property rights; clarity of preservation path and } \\
\text { ensuing responsibilities; credible preservation plan; proven capacity of repository; legal deposit } \\
\text { preservation copying; post-cancellation access service; persistent identifiers used consistently; } \\
\text { non-proprietary formats used and validated; minimal or well managed external dependencies. }\end{array}$} \\
\hline \multicolumn{3}{|c|}{$\begin{array}{l}2019 \text { Review } \\
\text { Published research outputs were introduced in 2017, though without reference to the capacity of } \\
\text { the repository infrastructure. The jury has amended this category slightly to presume the } \\
\text { existence of repository infrastructure and noted that the aggravating conditions which introduce } \\
\text { risks and good practice enhancements which reduce it are mostly relevant to repository } \\
\text { operations. }\end{array}$} \\
\hline \multicolumn{3}{|c|}{$\begin{array}{l}\text { Additional Jury Comments } \\
\text { See also: } \\
\text { - Beagrie, N (2013) Preservation, Trust and Continuing Access for E-Journals, DPC } \\
\text { Technology Watch Report 13-04, online at: http://dx.doi.org/10.7207/twr13-04 } \\
\text { - Morrissey, S and Kirchhoff, A (2014) Preserving E-Books, DPC Technology Watch Report } \\
\text { 14-01, online at: } \underline{\text { http://dx.doi.org/10.7207/twr14-01 }}\end{array}$} \\
\hline
\end{tabular}




\begin{tabular}{|c|c|c|}
\hline \multicolumn{2}{|c|}{$\begin{array}{l}\text { Recently Commissioned or Completed Media } \\
\text { Art }\end{array}$} & \\
\hline \multicolumn{2}{|c|}{$\begin{array}{l}\text { Media art currently displayed in a gallery or in the process o } \\
\text { being displayed. }\end{array}$} & \\
\hline Group: Media Art & Trend in 2020: & Consensus Decision \\
\hline Added to List: New Entry & No Change & Previous category: New Entry \\
\hline $\begin{array}{l}\text { Imminence of Action } \\
\text { Action is recommended } \\
\text { within three years, detailed } \\
\text { assessment within one year }\end{array}$ & $\begin{array}{l}\text { Significance of Loss } \\
\text { The loss of tools, data or } \\
\text { services within this group } \\
\text { would impact on many } \\
\text { people and sectors. }\end{array}$ & $\begin{array}{l}\text { Effort to Preserve } \\
\text { It would require a major effort to } \\
\text { preserve materials in this group, } \\
\text { including the development of new } \\
\text { tools or techniques. }\end{array}$ \\
\hline
\end{tabular}

\section{Examples}

Media art recently acquired by galleries that utilizes specific hardware and software in order to be accessed or exhibited.

\section{'Endangered' in the Presence of Aggravating Conditions}

Lack of documentation to enable maintenance; lack of clarity with respect to intellectual property; complex interdependencies on specific hardware, software or operating systems; lack of capacity in the gallery or workshop; lack of strategic investment; complex external dependencies

\section{Lower Risk in the Presence of Good Practice}

Strong documentation; clarity of preservation path and ensuing responsibilities; proven preservation plan; capacity of workshop to support art work at de-installation; capacity of gallery to conserve after de-installation; capacity of gallery to re-install work

\section{Review}

Media Art was introduced in 2017, though with particular reference to historical media art which was categorised as 'critically endangered'. The Jury introduced this entry to ensure greater specificity in its recommendation. It is intended to represent works commissioned in the last five years where there is a reasonable expectation that documentation has been produced or could still be obtained.

\section{Additional Jury Comments}

By the time digital art, time-based media etc. has entered into the 'permanent' care of a stewarding institution many of its technologies are already end-of-life, unsupported, or the hardware components have deteriorated. Often the expertise to maintain these many interacting components sits outside the host organisation, with a technical supplier to the gallery, and this is in itself vulnerable to business change. Although there are a few exceptions, there is need for greater capacity within the museum and gallery sector to address the challenges that arise. 


\begin{tabular}{|c|c|c|}
\hline \multicolumn{2}{|c|}{ Research data published through repositories } & \\
\hline \multicolumn{2}{|c|}{$\begin{array}{l}\text { Research data published through digital repositories or } \\
\text { other services providers with specialist skills to manage the } \\
\text { data and an ongoing commitment to ensure preservation. }\end{array}$} & \\
\hline Group: Research Outputs & Trend in 2020: & Consensus Decision \\
\hline Added to List: 2019 & No Change & Previous category: No Change \\
\hline \multicolumn{3}{|c|}{$\begin{array}{l}\text { Recognized data repositories in specialist disciplines; institutional data repositories in subject } \\
\text { specialist centres and partnerships }\end{array}$} \\
\hline \multicolumn{3}{|c|}{$\begin{array}{l}\text { Lack of long-term commitment; lack of user community; lack of visibility to potential depositors; } \\
\text { lack of institutional commitment }\end{array}$} \\
\hline \multicolumn{3}{|c|}{$\begin{array}{l}\text { 'Lower Risk' in the Presence of Good Practice } \\
\text { Certification and documented good practice; effective documentation requirements for } \\
\text { depositors; proven financial sustainability; skilled staff; participation in the digital preservation } \\
\text { community }\end{array}$} \\
\hline \multicolumn{3}{|c|}{$\begin{array}{l}2019 \text { Review } \\
\text { Research data was introduced in 2017, though without reference to the capacity of the repository } \\
\text { infrastructure. The Jury has split this entry into a range of contexts for research outputs, and } \\
\text { presents this as the best outcome for research data: a well-founded repository with the capacity } \\
\text { and commitment to ensure preservation, and the capability in part through their own professional } \\
\text { development activities to become 'lower risk' }\end{array}$} \\
\hline Additional Jury Comments & & \\
\hline
\end{tabular}




\section{Endangered}

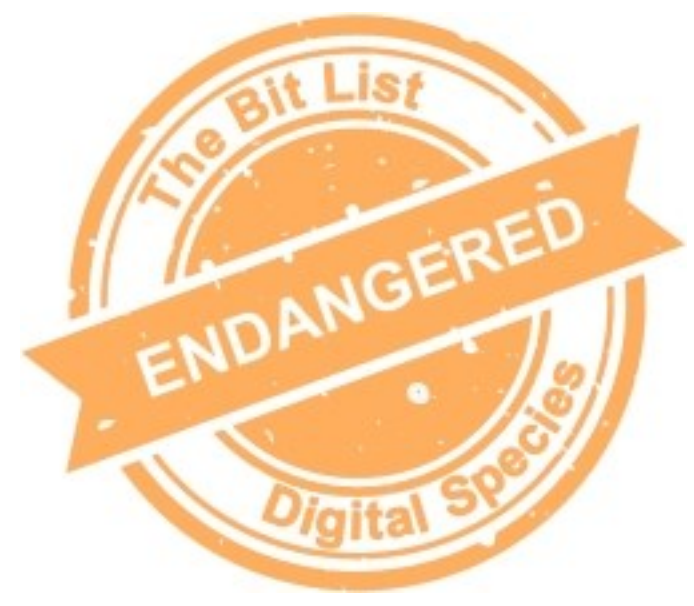

Digital materials are listed Endangered when they face material technical challenges to preservation or responsibility for care is poorly understood, or where the responsible agencies are poorly equipped to meet preservation needs.

This classification includes Vulnerable materials in the presence of aggravating conditions, and Critically Endangered materials in the presence of good practice. 


\begin{tabular}{|c|c|c|}
\hline \multicolumn{2}{|c|}{ 3d Digital Engineering Drawings } & \\
\hline \multicolumn{3}{|c|}{$\begin{array}{l}\text { 3D digital engineering models produced as part of building } \\
\text { or engineering design processes. The production of such } \\
\text { drawings has progressed from a digital analogue of paper to } \\
\text { complex digital environments such as BIM (Building } \\
\text { Information Modelling) which combine original drawings, } \\
\text { libraries of compound objects, and links to external data } \\
\text { sets such as about the performance of materials and } \\
\text { maintenance of parts. }\end{array}$} \\
\hline Grol & & \\
\hline (t) & & \\
\hline 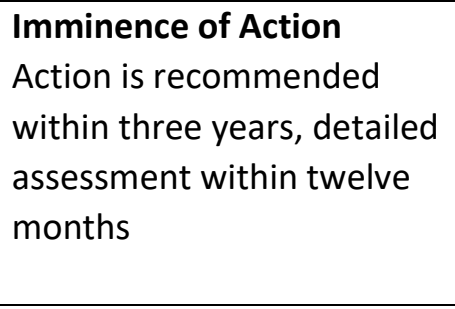 & & \\
\hline \multicolumn{3}{|c|}{$\begin{array}{l}\text { Examples } \\
\text { Building Information Management, Computer Aided Design, Product Data Management in } \\
\text { engineering and architecture, }\end{array}$} \\
\hline \multicolumn{3}{|c|}{$\begin{array}{l}\text { ‘Critically Endangered’ in the Presence of Aggravating Conditions } \\
\text { Lack of preservation mandate or collecting institution; lack of preservation capability in data } \\
\text { owner; irregularities in supply chains; complex or long data supply chains; dependencies on } \\
\text { proprietary software or formats; lack of persistent identifiers; poorly managed IPR; temporary } \\
\text { joint-venture companies; poor records management; poor regulatory compliance; encryption. }\end{array}$} \\
\hline \multicolumn{3}{|c|}{$\begin{array}{l}\text { 'Vulnerable' in the Presence of Good Practice } \\
\text { Well managed data infrastructure; preservation from the point creation; carefully managed IPR; } \\
\text { persistent identifiers; well managed records management processes; recognition of preservation } \\
\text { requirements at highest levels; strategic investment in digital preservation; host clearly identified; } \\
\text { participation in digital preservation community. }\end{array}$} \\
\hline \multicolumn{3}{|c|}{$\begin{array}{l}2019 \text { Review } \\
\text { This entry was first submitted in } 2017 \text { when the Jury lacked the capacity to consider it in detail. It } \\
\text { has been assessed this time with additional expertise co-opted. Nonetheless it remains a very } \\
\text { broad category including major one-off construction and engineering projects, a long tail of more } \\
\text { minor building programmes, as well as large volume but homogenous production processes in } \\
\text { engineering. The key consideration is that the lifecycle of the products and the data which } \\
\text { describes them vastly exceeds the short lifecycles of the infrastructures on which they are } \\
\text { designed. This challenge is compounded by supply chains that may involve many different stages } \\
\text { of production, as well as the delivery of large projects through transitory joint ventures companies } \\
\text { that have no residual mechanism or capacity to preserve the data thereafter. }\end{array}$} \\
\hline \multicolumn{3}{|c|}{$\begin{array}{l}\text { Additional Jury Comments } \\
\text { Data in this category enables the safety and security of critical infrastructure, but the } \\
\text { responsibility to maintain data is unclear, nor are retention periods clear. Although examples of } \\
\text { good practice can be identified, the extent to which there are working solutions at large seems } \\
\text { doubtful and it's surprising that there are not more, and more diverse, success stories to report. }\end{array}$} \\
\hline
\end{tabular}




\begin{tabular}{|c|c|c|}
\hline \multicolumn{2}{|c|}{$\begin{array}{l}\text { Born Digital Photographs and Video shared via } \\
\text { Social Media or Uploaded to Cloud Services }\end{array}$} & \\
\hline \multicolumn{2}{|c|}{$\begin{array}{l}\text { Digital images or video with no analogue equivalent and } \\
\text { where the only copy is online with a social media platform } \\
\text { or cloud image hosting service. }\end{array}$} & \\
\hline Group & & onsensus Decision \\
\hline Added to & Trend towards gr & revious category: Endangered \\
\hline $\begin{array}{l}\text { Imminence of Action } \\
\text { Action is recommended } \\
\text { within three years, detailed } \\
\text { assessment within twelve } \\
\text { months }\end{array}$ & $\begin{array}{l}\text { Significance of Loss } \\
\text { The loss of tools, data or } \\
\text { services within this group } \\
\text { would impact on people and } \\
\text { sectors around the world. }\end{array}$ & $\begin{array}{l}\text { Effort to Preserve } \\
\text { It would require a major effort to } \\
\text { address losses in this group, } \\
\text { possibly requiring the } \\
\text { development of new preservation } \\
\text { tools or techniques. }\end{array}$ \\
\hline \multicolumn{3}{|c|}{$\begin{array}{l}\text { Examples } \\
\text { Flickr; Vimeo; YouTube; Instagram; Periscope; DropBox; Facebook; Twitter. }\end{array}$} \\
\hline \multicolumn{3}{|c|}{$\begin{array}{l}\text { ‘Critically Endangered' in the Presence of Aggravating Conditions } \\
\text { lack of preservation capacity in provider; lack of explicit preservation commitment or incentive } \\
\text { from provider to preserve; lack of storage replication by provider; dependence on proprietary } \\
\text { products or formats; poor management of data protection; inaccessibility to web archiving } \\
\text { services; political or commercial interference; lack of offline equivalent; over-abundance; poorly } \\
\text { managed intellectual property rights; lossy compression applied in upload scripts. }\end{array}$} \\
\hline \multicolumn{3}{|c|}{$\begin{array}{l}\text { 'Vulnerable' in the Presence of Good Practice } \\
\text { Offline backup; lossless compression; good documentation; accessible to web harvesting; clarity } \\
\text { of intellectual property rights which enable preservation; credible preservation commitment from } \\
\text { service provider; export pathway. }\end{array}$} \\
\hline \multicolumn{3}{|c|}{$\begin{array}{l}2019 \text { Review } \\
\text { This entry was introduced in } 2018 \text { and this time has been placed within a wider social media } \\
\text { group. It shares many of the challenges with other entries in the group, with a dependency on a } \\
\text { global service provider whose business model can only be presumed and tied to users via } \\
\text { asymmetrical contracts that favour the supplier. Moreover, because these services have a low } \\
\text { barrier to entry they are used by agencies or individuals least able to respond to closure or loss. } \\
\text { Images and videos present distinct preservation challenges which need to be addressed. }\end{array}$} \\
\hline \multicolumn{3}{|c|}{$\begin{array}{l}\text { The platforms themselves get in the way. If there were enough money and an institution willing to } \\
\text { take on large datasets or archiving via existing web archiving tools, with the permission of rights } \\
\text { holders and the platforms it would probably be possible to harvest this content. This gets trickier } \\
\text { with the closed networks and content in user accounts that are not accessible to the public, so } \\
\text { web archives wouldn't necessarily be able to step in. Instead, individual users armed with } \\
\text { personal digital archiving tools and knowledge would need to preserve their own data. }\end{array}$} \\
\hline 2020 Trend: The closure of $t$ & EverAlbum photo storage ser & $\begin{array}{l}\text { ce in August and changes to the } \\
\text { f closures within the photo sharing }\end{array}$ \\
\hline
\end{tabular}




\begin{tabular}{|c|c|c|}
\hline \multicolumn{2}{|c|}{$\begin{array}{l}\text { Completed investigations based on open source } \\
\text { intelligence sources }\end{array}$} & \\
\hline \multicolumn{2}{|c|}{$\begin{array}{l}\text { Open source social media and web content that has been } \\
\text { used to support the conclusions of crowd-sourced } \\
\text { investigation and fact-checking in political or military } \\
\text { conflict. }\end{array}$} & \\
\hline Group: Digital Legal Records & Trend in 2020: & Unanimous Decision \\
\hline Added to List: 2019 & No Change & Previous category: New Entry \\
\hline $\begin{array}{l}\text { Imminence of Action } \\
\text { Action is recommended } \\
\text { within three years, detailed } \\
\text { assessment within twelve } \\
\text { months }\end{array}$ & $\begin{array}{l}\text { Significance of Loss } \\
\text { The loss of tools, data or } \\
\text { services within this group } \\
\text { would impact on people and } \\
\text { sectors around the world. }\end{array}$ & $\begin{array}{l}\text { Effort to Preserve } \\
\text { It would require a small effort to } \\
\text { preserve materials in this group, } \\
\text { with the deployment of proven } \\
\text { tools or techniques. }\end{array}$ \\
\hline \multicolumn{3}{|c|}{$\begin{array}{l}\text { Examples } \\
\text { Social media sources relating to recent conflicts, such as in Ukraine. }\end{array}$} \\
\hline \multicolumn{3}{|c|}{$\begin{array}{l}\text { Critically Endangered in the presence of Aggravating Conditions } \\
\text { Encryption; loss of authenticity; lack of preservation agency; limited or no digital preservation } \\
\text { capability. }\end{array}$} \\
\hline \multicolumn{3}{|c|}{$\begin{array}{l}\text { 'Vulnerable' in the Presence of Good Practice } \\
\text { Offline backup captured by journalist or investigating authority; materials presented and } \\
\text { documented in court; court able to deliver preservation; authenticity protected }\end{array}$} \\
\hline \multicolumn{3}{|c|}{$\begin{array}{l}2019 \text { Review } \\
\text { This is a new entry received through open submission in } 2019 \text { and subsequently split into three } \\
\text { elements by the Jury, relating to current, recent and historic sources. This entry relates to } \\
\text { materials used in evidence in completed investigations, as well as those presented to courts or } \\
\text { other investigatory agencies. }\end{array}$} \\
\hline \multirow{2}{*}{\multicolumn{3}{|c|}{$\begin{array}{l}\text { Social media companies have a policy to take down or suppress content that they consider to be } \\
\text { propaganda for terrorist groups. This has had the unintended consequence of deleting or } \\
\text { supressing content that was being used in open source investigation or fact checking for } \\
\text { journalistic or judicial purposes, and which may therefore be an impediment to refutation or } \\
\text { prosecution. However, a new generation of cloud based services now allow investigators to copy } \\
\text { and stabilise content to private accounts in the process of investigating it: so the ethical } \\
\text { requirements of social media companies and the integrity of investigation are both served. } \\
\text { The Jury notes that the such content remains at risk, but the presentation of data to a court or } \\
\text { prosecuting authority, or the publication through news media implies the introduction of a long- } \\
\text { term preservation function. }\end{array}$}} \\
\hline & & \\
\hline Additional Jury Comments & & \\
\hline
\end{tabular}




\begin{tabular}{|c|c|c|}
\hline \multicolumn{2}{|c|}{ Consumer Cloud-based Utilities } & \\
\hline \multicolumn{2}{|c|}{$\begin{array}{l}\text { Free online utilities offered at no cost to end users, but with } \\
\text { a business model based on gathering and reselling } \\
\text { consumer insights. This entry includes data produced and } \\
\text { stored and accessed within the utilities. }\end{array}$} & \\
\hline Group: Social media & Trend in 2020: & Consensus Decision \\
\hline Added to List: 2019 & & Previous category: New Entry \\
\hline $\begin{array}{l}\text { Imminence of Action } \\
\text { Action is recommended } \\
\text { within three years, detailed } \\
\text { assessment within twelve } \\
\text { months }\end{array}$ & $\begin{array}{l}\text { Significance of Loss } \\
\text { The loss of tools, data or } \\
\text { services within this group } \\
\text { would impact on people and } \\
\text { sectors around the world. }\end{array}$ & $\begin{array}{l}\text { Effort to Preserve } \\
\text { It would require a major effort to } \\
\text { address losses in this group, } \\
\text { possibly requiring the } \\
\text { development of new preservation } \\
\text { tools or techniques. }\end{array}$ \\
\hline \multicolumn{3}{|c|}{$\begin{array}{l}\text { Examples } \\
\text { Google Docs, Google Sheets, Gmail, Hotmail, Yahoo Mail, Prezi }\end{array}$} \\
\hline \multicolumn{3}{|c|}{$\begin{array}{l}\text { ‘Critically Endangered’ in the Presence of Aggravating Conditions } \\
\text { Unstable business model from service provider; service provider bought over or pivots to new } \\
\text { market opportunities; lack of investment in infrastructure; lack of offline copy. }\end{array}$} \\
\hline \multicolumn{3}{|c|}{$\begin{array}{l}\text { Vulnerable in the Presence of Good Practice } \\
\text { Clear export and migration pathways; preservation responsibility shouldered by the service } \\
\text { provider; }\end{array}$} \\
\hline \multicolumn{3}{|c|}{$\begin{array}{l}2019 \text { Review } \\
\text { The judges have introduced this entry as a subset of a previous entry, emphasizing the different } \\
\text { threats faced by services that are 'paid-for' versus 'free-at-the-point-of-use' tools. Both depend on } \\
\text { the business model of the vendor and the terms and conditions which they impose. This group of } \\
\text { digital materials the business model and sustainability can only be presumed and contracts tend } \\
\text { to be asymmetrical in favour of the supplier. Moreover, because these services have a low barrier } \\
\text { to entry they may be favoured by agencies or individuals least able to respond to closure or loss. }\end{array}$} \\
\hline \multicolumn{3}{|c|}{$\begin{array}{l}\text { Additional Jury Comments } \\
\text { If we're talking about the entire platforms and risk of the entirety of data on these, then the } \\
\text { concern is that the corporation providing the service suddenly decides it's no longer of value to } \\
\text { them. In these circumstances material could be removed quickly. That has happened already with } \\
\text { some services and will certainly be seen again. Preservation is not a commitment that most } \\
\text { providers make. Cultural Heritage organizations need to determine what out of these services is } \\
\text { important to tackle and may use traditional web archiving tools or email preservation tools to get } \\
\text { what they can. Possibly new tools around preserving data in these services for particular accounts } \\
\text { - a sort of personal digital archive option - could be helpful and encouraged. }\end{array}$} \\
\hline
\end{tabular}




\begin{tabular}{|c|c|c|}
\hline \multicolumn{2}{|c|}{ Consumer social media free at the point of use } & \\
\hline \multicolumn{2}{|c|}{$\begin{array}{l}\text { Social media services offered free at the point of use with a } \\
\text { subscription model based on reselling user behavior and/or } \\
\text { advertising. }\end{array}$} & \\
\hline Group & & onsensus Decision \\
\hline Added to List: & & revious category: Endangered \\
\hline $\begin{array}{l}\text { Imminence of Action } \\
\text { Action is recommended } \\
\text { within three years, detailed } \\
\text { assessment within twelve } \\
\text { months }\end{array}$ & $\begin{array}{l}\text { Significance of Loss } \\
\text { The loss of tools, data or } \\
\text { services within this group } \\
\text { would impact on people and } \\
\text { sectors around the world }\end{array}$ & $\begin{array}{l}\text { Effort to Preserve } \\
\text { It would require a major effort to } \\
\text { address losses in this group, } \\
\text { possibly requiring the } \\
\text { development of new preservation } \\
\text { tools or techniques. }\end{array}$ \\
\hline \multicolumn{3}{|c|}{$\begin{array}{l}\text { Examples } \\
\text { Flickr, Vimeo, YouTube, Instagram, Periscope, DropBox, Facebook, Twitter, Pinterest, Yahoo } \\
\text { Groups }\end{array}$} \\
\hline \multicolumn{3}{|c|}{$\begin{array}{l}\text { 'Critically Endangered' in the Presence of Aggravating Conditions } \\
\text { Lack of preservation capacity in provider; Lack of preservation commitment or incentive from } \\
\text { provider; Lack of storage replication; proprietary products or formats; poor data protection; } \\
\text { inaccessibility to web archiving; political or commercial interference; Lack of offline equivalent; } \\
\text { super-abundance; poorly managed IPR; Lossy compression in upload scripts. }\end{array}$} \\
\hline \multicolumn{3}{|c|}{$\begin{array}{l}\text { Vulnerable in the Presence of Good Practice } \\
\text { Offline backup and documentation of media assets; Migration plan; Early warning from vendors; } \\
\text { Roadmap from vendors; Accessible to web harvest; Suitable export functionality; Licencing } \\
\text { enables preservation; Preservation commitment from vendor; Preservation capability in vendor; } \\
\text { Resilient to hacking; Selection criteria; }\end{array}$} \\
\hline \multicolumn{3}{|c|}{$\begin{array}{l}2019 \text { Review } \\
\text { The judges have introduced this entry as a subset of a previous entry, emphasizing the different } \\
\text { threats faced by online services that are 'paid-for' versus 'free-at-the-point-of-use'. Both depend } \\
\text { on the business model of the vendor and the terms which they impose. For this group of digital } \\
\text { materials the business model and sustainability can only be guessed and contracts tend to be } \\
\text { asymmetrical in favour of the supplier. Moreover, because these services have a low barrier to } \\
\text { entry they may be favoured by agencies or individuals least able to respond to closure or loss. }\end{array}$} \\
\hline \multicolumn{3}{|c|}{$\begin{array}{l}\text { Additional Jury Comments } \\
\text { Social media capture via web harvesting has become increasingly difficult. The platforms continue } \\
\text { to put up barriers to automated capture that prevent preservation of even so-called public } \\
\text { content. For example, campaign websites or other election-related content that is only published } \\
\text { in Facebook or on Twitter, because these services are "Free". This content is of particular concern } \\
\text { as it appears on no other website. Web archivists are constantly shifting strategies and } \\
\text { approaches and trying out new (but limited) tools to best capture this content. If we cannot } \\
\text { successfully preserve these platforms, we are missing out on documenting organizations, } \\
\text { campaigns and elections around the globe. Much of this data exists as data sets based on } \\
\text { aggregated use rather than individual files. }\end{array}$} \\
\hline
\end{tabular}




\begin{tabular}{|c|c|c|}
\hline \multicolumn{2}{|c|}{ Contractual Documents and Related Records } & \\
\hline \multicolumn{2}{|c|}{$\begin{array}{l}\text { Documents, correspondence and other records created in } \\
\text { the course of contractual dealings between individuals and } \\
\text { agencies, especially where the subjects are of long duration } \\
\text { and may be subject to legal scrutiny at undefined points in } \\
\text { the distant future. }\end{array}$} & \\
\hline Group: Digital Legal Records & Trend in 2020: & Consensus Decision \\
\hline Added to List: 2017 & Trend towards greater risk & Previous category: Endangered \\
\hline $\begin{array}{l}\text { Imminence of Action } \\
\text { Action is recommended } \\
\text { within three years, detailed } \\
\text { assessment within twelve } \\
\text { months }\end{array}$ & $\begin{array}{l}\text { Significance of Loss } \\
\text { The loss of tools, data or } \\
\text { services within this group } \\
\text { would impact on many } \\
\text { people and sectors. }\end{array}$ & $\begin{array}{l}\text { Effort to Preserve } \\
\text { It would require a small effort to } \\
\text { preserve materials in this group, } \\
\text { with the deployment of proven } \\
\text { tools or techniques. }\end{array}$ \\
\hline
\end{tabular}

\section{Examples}

Contracts, receipts, correspondence, license agreements, building consent, warranties, and any other document or record that represents a legally binding transaction or permission. Such records may be useful in the avoidance or resolution of disputes whether in court or prior to proceedings. Includes Online Terms and Conditions for e-commerce or end-user agreements for services.

\section{'Critically Endangered' in the Presence of Aggravating Conditions}

Loss of context; loss of authenticity or integrity; external dependencies; poor storage; lack of understanding; churn of staff; poorly framed or over-zealous disposal; ill-informed records management; misplaced fears with respect to data protection, encryption.

\section{Vulnerable in the Presence of Good Practice}

Well managed data infrastructure; preservation enabled at the point of creation; carefully managed authenticity; use of persistent identifiers; finding aids; well managed records management processes; application of records management standards

\section{Review}

This entry is a subset of an entry made in 2017 for 'Digital Legal Records and Evidence' which the Jury has decided to split into four more discrete entries this year. It has significant overlap with a separate entry about Pension Mortgage and Insurance Records, except that those are created explicitly with the expectation that they are tied to long-lifecycle products and are held by long lived agencies who provide those products. This entry notes that many digital records have value over the long term which may not be immediately obvious at the point of creation.

\section{Additional Jury Comments}

Legal agreements should be dealt with through records management standards and processes with agencies who have experience of handling this.

2020 Trend: The Covid Pandemic has caused profound dislocation across the economy and placed many companies and agencies at financial risk. The likelihood of liquidation, mergers or acquisitions means that these records are trending towards greater risk. 


\begin{tabular}{|c|c|c|}
\hline \multicolumn{2}{|c|}{ Current Portable Magnetic Media } & \\
\hline \multicolumn{2}{|c|}{$\begin{array}{l}\text { Materials saved to magnetic tape, portable hard disks or } \\
\text { other magnetic media in the last five years where the reader } \\
\text { devices are still supported and can be integrated easily into } \\
\text { hardware infrastructure. }\end{array}$} & \\
\hline Group: & Trel & Consensus Decision \\
\hline Added to List: 2019 & No $\mathrm{C}$ & Previous category: New Entry \\
\hline $\begin{array}{l}\text { Imminence of Action } \\
\text { Action is recommended } \\
\text { within three years, detailed } \\
\text { assessment within twelve } \\
\text { months }\end{array}$ & $\begin{array}{l}\text { Significance of Loss } \\
\text { The loss of tools, data or } \\
\text { services within this group } \\
\text { would impact on many } \\
\text { people and sectors. }\end{array}$ & $\begin{array}{l}\text { Effort to Preserve } \\
\text { It would require a small effort to } \\
\text { address losses in this group, } \\
\text { requiring the application of proven } \\
\text { preservation tools or techniques. }\end{array}$ \\
\hline \multicolumn{3}{|c|}{$\begin{array}{l}\text { Examples } \\
\text { LTO8 tapes; portable hard disks }\end{array}$} \\
\hline \multicolumn{3}{|c|}{$\begin{array}{l}\text { ‘Critically Endangered' in the Presence of Aggravating Conditions } \\
\text { Poor storage conditions; encryption; digital rights management; lack of replication; lack of } \\
\text { documentation; lack of periodic testing; lack of refreshment pathway; lack of access to readers; } \\
\text { out of manufacturers' warranty or no warranty; storage within paper files. }\end{array}$} \\
\hline \multicolumn{3}{|c|}{$\begin{array}{l}\text { Vulnerable in the Presence of Good Practice } \\
\text { Regular review and testing; replication; refreshment plan; comprehensive documentation; high } \\
\text { quality storage; regular maintenance of readers; multiple readers available. }\end{array}$} \\
\hline \multicolumn{3}{|c|}{$\begin{array}{l}2019 \text { Review } \\
\text { The judges introduced this entry to ensure that the range of media storage is properly assessed } \\
\text { and presented. Magnetic media is typically more fragile than optical media because it is } \\
\text { susceptible to 'bitrot' and magnetic damage in ways that optical media are not. }\end{array}$} \\
\hline \multicolumn{3}{|c|}{$\begin{array}{l}\text { Additional Jury Comments } \\
\text { This entry is highly dependent on who is looking after the portable media but made more difficult } \\
\text { over time. The lack of granularity in the definition means that only general advice can be offered } \\
\text { such as to refresh media. In time it may yet be more useful to split all storage media (maybe } 100 \\
\text { items long) with an indication of how long these can be expected to last. In many cases obsolete } \\
\text { media can be recovered by specialist companies but the cost of employing them can become an } \\
\text { aggravating condition. } \\
\text { It's important to emphasize that the short lifetime of many storage devices is not a problem to be } \\
\text { solved with new long-lasting storage technologies (and indeed, many inventions have come and } \\
\text { gone). Cheap, commodity storage has been purposely designed to deliver value at a low price for } \\
\text { a short time, and therefore management and preservation processes for monitoring and } \\
\text { refreshment need to take these characteristics into account. }\end{array}$} \\
\hline
\end{tabular}




\begin{tabular}{|c|c|c|}
\hline \multicolumn{2}{|c|}{ Current Portable Optical Media } & \\
\hline \multicolumn{2}{|c|}{$\begin{array}{l}\text { Materials saved to DVDs, CDs or other optical media in the } \\
\text { last five years where the reader devices are still supported } \\
\text { and can be integrated easily into hardware infrastructure }\end{array}$} & \\
\hline Group: Portable Media & Trend in 2020: & Consensus Decision \\
\hline Added to List: 2019 & No Change & Previous category: New Entry \\
\hline $\begin{array}{l}\text { Imminence of Action } \\
\text { Action is recommended } \\
\text { within three years, detailed } \\
\text { assessment within twelve } \\
\text { months }\end{array}$ & $\begin{array}{l}\text { Significance of Loss } \\
\text { The loss of tools, data or } \\
\text { services within this group } \\
\text { would impact on many } \\
\text { people and sectors. }\end{array}$ & $\begin{array}{l}\text { Effort to Preserve } \\
\text { It would require a small effort to } \\
\text { address losses in this group, } \\
\text { requiring the application of proven } \\
\text { preservation tools or techniques. }\end{array}$ \\
\hline \multicolumn{3}{|c|}{$\begin{array}{l}\text { Examples } \\
\text { CDs, DVDs produced in the last five years }\end{array}$} \\
\hline \multicolumn{3}{|c|}{$\begin{array}{l}\text { 'Critically Endangered' in the Presence of Aggravating Conditions } \\
\text { Poor storage conditions; encryption; digital rights management; lack of replication; lack of } \\
\text { documentation; lack of periodic testing; lack of refreshment pathway; lack of access to readers; } \\
\text { out of manufacturers' warranty or no warranty; storage in paper files. }\end{array}$} \\
\hline \multicolumn{3}{|c|}{$\begin{array}{l}\text { Regular review and testing; replication; refreshment plan; comprehensive documentation; high } \\
\text { quality storage; regular maintenance of readers; multiple readers available; }\end{array}$} \\
\hline \multicolumn{3}{|c|}{$\begin{array}{l}2019 \text { Review } \\
\text { The judges have introduced this entry to ensure that the range of media storage is properly } \\
\text { assessed and presented. }\end{array}$} \\
\hline \multicolumn{3}{|c|}{$\begin{array}{l}\text { Additional Jury Comments } \\
\text { This entry is highly dependent on who is looking after the portable media but made more difficult } \\
\text { over time. The lack of granularity in the definition means that only general advice can be offered } \\
\text { such as to refresh media. In time it may yet be more useful to split all storage media (maybe } 100 \\
\text { items long) with an indication of how long these can be expected to last. In many cases obsolete } \\
\text { media can be recovered by specialist companies but the cost of employing them can become an } \\
\text { aggravating condition. }\end{array}$} \\
\hline
\end{tabular}




\begin{tabular}{|c|c|c|}
\hline \multicolumn{2}{|c|}{ Current Portable Solid-State Media } & \\
\hline \multicolumn{2}{|c|}{$\begin{array}{l}\text { Materials saved to flash drives or other solid-state media ir } \\
\text { the last five years where the reader devices are still } \\
\text { supported and can be integrated easily into hardware } \\
\text { infrastructure }\end{array}$} & \\
\hline Group: Portable Media & Trend in 2020: & Consensus Decision \\
\hline Added to List: 2019 & No Change & Previous category: New Entry \\
\hline $\begin{array}{l}\text { Imminence of Action } \\
\text { Action is recommended } \\
\text { within three years, detailed } \\
\text { assessment within twelve } \\
\text { months }\end{array}$ & $\begin{array}{l}\text { Significance of Loss } \\
\text { The loss of tools, data or } \\
\text { services within this group } \\
\text { would impact on many } \\
\text { people and sectors. }\end{array}$ & $\begin{array}{l}\text { Effort to Preserve } \\
\text { It would require a small effort to } \\
\text { address losses in this group, } \\
\text { requiring the application of proven } \\
\text { preservation tools or techniques. }\end{array}$ \\
\hline \multicolumn{3}{|c|}{$\begin{array}{l}\text { Examples } \\
\text { USB memory sticks; flash cards in cameras; solid state portable hard disks }\end{array}$} \\
\hline \multicolumn{3}{|c|}{$\begin{array}{l}\text { ‘Critically Endangered' in the Presence of Aggravating Conditions } \\
\text { Poor storage conditions; encryption; digital rights management; lack of replication; lack of } \\
\text { documentation; lack of periodic testing; lack of refreshment pathway; lack of access to readers; } \\
\text { out of manufacturers' warranty or no warranty; storage in paper files. }\end{array}$} \\
\hline \multicolumn{3}{|c|}{$\begin{array}{l}\text { Vulnerable in the Presence of Good Practice } \\
\text { Regular review and testing; replication; refreshment plan; comprehensive documentation; high } \\
\text { quality storage; regular maintenance of readers; multiple readers available; }\end{array}$} \\
\hline \multicolumn{3}{|c|}{$\begin{array}{l}2019 \text { Review } \\
\text { The judges have introduced this entry to ensure that the range of media storage is properly } \\
\text { assessed and presented. }\end{array}$} \\
\hline \multicolumn{3}{|c|}{$\begin{array}{l}\text { Additional Jury Comments } \\
\text { This entry is highly dependent on who is looking after the portable media but made more difficult } \\
\text { over time. The lack of granularity in the definition means that only general advice can be offered } \\
\text { such as to refresh media. In time it may yet be more useful to split all storage media (maybe } 100 \\
\text { items long) with an indication of how long these can be expected to last. In many cases obsolete } \\
\text { media can be recovered by specialist companies but the cost of employing them can become an } \\
\text { aggravating condition. }\end{array}$} \\
\hline
\end{tabular}




\begin{tabular}{|c|c|c|}
\hline \multicolumn{2}{|c|}{ Digital Materials in Museums and Galleries } & \\
\hline \multicolumn{2}{|c|}{$\begin{array}{l}\text { All manner of digital materials held in museums to support } \\
\text { the access, interpretation and management of physical } \\
\text { collections, including material generated by interaction with } \\
\text { the public and in the course of research. It excludes those } \\
\text { small amounts of digital material formally accessioned into } \\
\text { museum collections. }\end{array}$} & \\
\hline Group: Museum Data & Trend in 2020: & Consensus Decision \\
\hline Added to List: 2019 & Trend towards greater risk & Previous category: New Entry \\
\hline $\begin{array}{l}\text { Imminence of Action } \\
\text { Action is recommended } \\
\text { within three years, detailed } \\
\text { assessment within twelve } \\
\text { months }\end{array}$ & $\begin{array}{l}\text { Significance of Loss } \\
\text { The loss of tools, data or } \\
\text { services within this group } \\
\text { would impact on many } \\
\text { people and sectors. }\end{array}$ & $\begin{array}{l}\text { Effort to Preserve } \\
\text { It would require a small effort to } \\
\text { address losses in this group, } \\
\text { requiring the application of proven } \\
\text { preservation tools or techniques. }\end{array}$ \\
\hline
\end{tabular}

Examples: Digital photography, video, sound, oral histories, collections management systems, conservation records, exhibition records, archives, operational or business records, scientific research outputs, correspondence, social media, $3 \mathrm{~d}$ digitization.

'Critically Endangered' in the Presence of Aggravating Conditions

Lack of repository infrastructure; external dependencies; dependency on cloud provider; poor storage; churn of staff; significant volumes or diversity of data; poorly developed digitization specifications; ill-informed records management policy; conflation of access with preservation; poorly developed migration or normalization; longstanding protocols or procedures that apply unsuitable paper processes to digital materials; inability to assume responsibility; encryption

'Vulnerable' in the Presence of Good Practice

Repository and preservation infrastructure; strategic leadership; well-developed digitization and migration pathways; participation in the global digital preservation community;

2019 Review

This new entry brings together submissions from the open nomination process. The Jury takes the view that museums make creative use of digital technology but have weak incentives to preserve the outputs when compared to libraries or archives. Museums take responsibility for the care of physical collections in the long term which brings a derived requirement to preserve digital materials relating to those collections. The museum sector is lacking preservation capability.

\section{Additional Jury Comments}

This entry is very broadly defined, and whilst it is useful to draw attention to the challenges, it might usefully be disaggregated in the future. For example, museums have significant incentives to maintain collection catalogues for audit purposes, and to share these with the public. Such databases are likely to face less severe preservation challenges than data generated about the collection through museum operations, conservation or research. Related data sets present different challenges too. For example, 3D digitisation is a particular challenge for museums as preservation standards are deficient and easily overlooked in the enthusiasm for fashionable or eye-catching trends which purport to extend access. Moreover, this sector is incredibly diverse and different needs are likely to exist in different kinds of museum or gallery.

2020 Trend: Many museums and galleries, which often rely on visitors for income, have been closed for extended periods. In these circumstances of economic dislocation digital materials in museums and galleries records are likely to be at a greater risk than in 2019. 


\begin{tabular}{|c|c|c|}
\hline \multicolumn{2}{|c|}{ Digitally published sheet music } & \\
\hline \multicolumn{2}{|c|}{$\begin{array}{l}\text { Sheet music licensed and published in a variety of digital } \\
\text { formats and subject to copyright restrictions and often } \\
\text { protected by digital rights management technologies }\end{array}$} & \\
\hline Group: Sound and Vision & Trend in 2020: & Consensus Decision \\
\hline Added to List: 2019 & No Change & Previous category: New Entry \\
\hline $\begin{array}{l}\text { Imminence of Action } \\
\text { Action is recommended } \\
\text { within five years, detailed } \\
\text { assessment within twelve } \\
\text { months }\end{array}$ & $\begin{array}{l}\text { Significance of Loss } \\
\text { The loss of tools, data or } \\
\text { services within this group } \\
\text { would impact on people and } \\
\text { sectors around the world. }\end{array}$ & $\begin{array}{l}\text { Effort to Preserve } \\
\text { It would require a small effort to } \\
\text { address losses in this group, } \\
\text { requiring the application of proven } \\
\text { preservation tools or techniques. }\end{array}$ \\
\hline \multicolumn{3}{|c|}{$\begin{array}{l}\text { Examples } \\
\text { All manner of published sheet music including choral works, orchestral works, scores. }\end{array}$} \\
\hline \multicolumn{3}{|c|}{$\begin{array}{l}\text { ‘Critically Endangered’ in the Presence of Aggravating Conditions } \\
\text { Encryption; uncertainty over intellectual property rights; uncertain business model of publisher; } \\
\text { lack of legal deposit mandate. }\end{array}$} \\
\hline \multicolumn{3}{|c|}{$\begin{array}{l}\text { 'Vulnerable' in the Presence of Good Practice } \\
\text { Rights management conducive to preservation; held in a trusted repository; legal deposit copying } \\
\text { enabled. }\end{array}$} \\
\hline \multicolumn{3}{|c|}{$\begin{array}{l}2019 \text { Review } \\
\text { This is a new entry introduced by the Jury as a subset of 'Digital Music Production and Sharing' } \\
\text { which was reported in 2017. The Jury has split this into components to draw attention to the } \\
\text { different challenges faced by these different forms. This is recognisably the smallest of the group } \\
\text { and has connections to PDF and PDF/A as well as E-Book formats which are commonly used to } \\
\text { publish music. }\end{array}$} \\
\hline \multicolumn{3}{|c|}{$\begin{array}{l}\text { Additional Jury Comments } \\
\text { The commercial value of these materials should be a protection against their loss, and the history } \\
\text { of the music industry indicates that sheet music continues to have value, so even if an individual } \\
\text { organisation fails or its DRM servers go offline and some music becomes inaccessible it is not lost. } \\
\text { However, the difficulties of archiving DRM-locked files remain real. }\end{array}$} \\
\hline
\end{tabular}




\begin{tabular}{|c|c|c|}
\hline \multicolumn{2}{|c|}{$\begin{array}{l}\text { Digital music and ephemera shared on social } \\
\text { media }\end{array}$} & \\
\hline \multicolumn{2}{|c|}{$\begin{array}{l}\text { Digital materials created by musicians and fans as a by- } \\
\text { product of performance or recording, shared on websites } \\
\text { and other social media platforms. }\end{array}$} & \\
\hline Group & & onsensus Decision \\
\hline Added to List: 2019 & No & revious category: New Entry \\
\hline $\begin{array}{l}\text { Imminence of Action } \\
\text { Action is recommended } \\
\text { within three years, detailed } \\
\text { assessment within twelve } \\
\text { months }\end{array}$ & $\begin{array}{l}\text { Significance of Loss } \\
\text { The loss of tools, data or } \\
\text { services within this group } \\
\text { would impact on people and } \\
\text { sectors around the world. }\end{array}$ & $\begin{array}{l}\text { Effort to Preserve } \\
\text { It would require a major effort to } \\
\text { address losses in this group, } \\
\text { possibly requiring the } \\
\text { development of new preservation } \\
\text { tools or techniques. }\end{array}$ \\
\hline \multicolumn{3}{|c|}{$\begin{array}{l}\text { Examples } \\
\text { Fan sites; private or illicit recordings of concerts; informal music sharing between networks. }\end{array}$} \\
\hline \multicolumn{3}{|c|}{$\begin{array}{l}\text { 'Critically Endangered' in the Presence of Aggravating Conditions } \\
\text { Dependence on social media provider; lack of offline equivalent; infringing intellectual property } \\
\text { right; unstable or small community of interest; encryption }\end{array}$} \\
\hline \multicolumn{3}{|c|}{$\begin{array}{l}\text { Vulnerable in the Presence of Good Practice } \\
\text { Offline equivalent; intellectual property rights conducive to preservation; partnership with } \\
\text { collecting institution; availability to web archiving. }\end{array}$} \\
\hline \multicolumn{3}{|c|}{$\begin{array}{l}2019 \text { Review } \\
\text { This entry has been split out of the previous entry for 'Digital Music Production and Sharing' } \\
\text { though it has overlaps with other entries including those relating to social media as well as those } \\
\text { relating to community-generated content. It has been retained as a separate theme to emphasize } \\
\text { the context in which music is shared and enjoyed - a context which could be lost if our attention } \\
\text { were on products controlled by studios or artists. The recent case of the closure of 'Yahoo Groups' } \\
\text { serves to underline the fragility of community content hosted by third parties. }\end{array}$} \\
\hline \multicolumn{3}{|c|}{$\begin{array}{l}\text { Additional Jury Comments } \\
\text { The ephemera are increasingly stored on websites that themselves are fragile and are removed - } \\
\text { as we see with MySpace's removal of MP3s, Flickr's decision to delete vast numbers of images } \\
\text { held on free accounts and material lost as a result of Tumblr's policy changes on the definition of } \\
\text { pornography. Nothing held on these services can be relied on in archival timeframes }\end{array}$} \\
\hline
\end{tabular}




\begin{tabular}{|c|c|c|}
\hline \multicolumn{2}{|l|}{ Digital Radio Recordings } & \\
\hline \multicolumn{2}{|c|}{$\begin{array}{l}\text { Master recordings of radio broadcasts generated live but } \\
\text { often poorly stored thereafter. Eg: Offline recordings on } \\
\text { single LTO (Linear Tape Open) Tapes }\end{array}$} & \\
\hline Group: Sound and Vision & Trend in 2020: & onsensus Decision \\
\hline Added to List: 2017 & No Change & Previous category: Endangered \\
\hline $\begin{array}{l}\text { Imminence of Action } \\
\text { Action is recommended } \\
\text { within three years, detailed } \\
\text { assessment within twelve } \\
\text { months }\end{array}$ & $\begin{array}{l}\text { Significance of Loss } \\
\text { The loss of tools, data or } \\
\text { services within this group } \\
\text { would impact on people and } \\
\text { sectors around the world. }\end{array}$ & $\begin{array}{l}\text { Effort to Preserve } \\
\text { It would require a major effort to } \\
\text { address losses in this group, } \\
\text { possibly requiring the } \\
\text { development of new preservation } \\
\text { tools or techniques. }\end{array}$ \\
\hline \multicolumn{3}{|c|}{$\begin{array}{l}\text { Examples } \\
\text { Broadcast archives of UK commercial local radio; }\end{array}$} \\
\hline \multicolumn{3}{|c|}{$\begin{array}{l}\text { ‘Critically Endangered' in the Presence of Aggravating Conditions } \\
\text { Lack of archival mandate; lack of capability of archive; lack of policy or capacity within } \\
\text { broadcaster; small or unprofitable broadcaster; concern over intellectual property rights; } \\
\text { overzealous rights management protection; device or software dependence; dependence on } \\
\text { proprietary or obsolete formats; lack or loss of documentation; little use or inaccessibility; storage } \\
\text { (typically tapes) older than warranty; lack of media refreshment plan; lack of error or integrity } \\
\text { checking process; single copies }\end{array}$} \\
\hline \multicolumn{3}{|c|}{$\begin{array}{l}\text { Archival responsibility accepted and acted upon; replication; refreshment of media; good } \\
\text { documentation; active in digital preservation community; trusted repository; content re-used }\end{array}$} \\
\hline \multicolumn{3}{|c|}{$\begin{array}{l}2019 \text { Review } \\
\text { This category was reported explicitly in concern over recordings on LTO tapes. These provide } \\
\text { between } 15 \text { and } 30 \text { years' storage which may be less depending on usage and storage conditions. } \\
\text { LTO1 and LTO2 which were released in } 2000 \text { and } 2003 \text { respectively are now entering the final } \\
\text { phases of viability. Reader compatibility may be more problematic than media resilience however. } \\
\text { Drives supporting newer releases of the format are typically only compatible within two } \\
\text { generations and experience with the recently released LTO8 suggest that it is only backwardly } \\
\text { compatible to one generation. Therefore one major national archive and library has decided to } \\
\text { expedite migration away from LTO6 which is becoming obsolete more quickly than anticipated. } \\
\text { Through time, the risks to collections that have not been refreshed or replicated from early LTO } \\
\text { tapes expand. Thus, the overall trend is towards greater risk when collections are not migrated. } \\
\text { Older formats, perhaps as recently as LTO6, extinction events should be anticipated within two to } \\
\text { five years. }\end{array}$} \\
\hline $\begin{array}{l}\text { Additional Jury Comments } \\
\text { Broadcasters may keep their }\end{array}$ & ( & oeing comprehensively collected \\
\hline
\end{tabular}




\begin{tabular}{|c|c|c|}
\hline \multicolumn{2}{|c|}{ Electronic hospital and medical records } & \\
\hline \multicolumn{2}{|c|}{$\begin{array}{l}\text { Personal medical records and records of hospital treatment } \\
\text { are increasingly, if not uniformly born digital. By implication } \\
\text { those records should be retained through the life-time of } \\
\text { the patient and perhaps longer as required for } \\
\text { intergenerational study; and yet there is little evidence of } \\
\text { the medical profession participating in the digital } \\
\text { preservation community. }\end{array}$} & \\
\hline Grol & & nsensus Decision \\
\hline Adde & & Previous category: Of Concern \\
\hline $\begin{array}{l}\text { ecommended } \\
\text { ee years, detailed } \\
\text { it within twelve }\end{array}$ & data or & $\begin{array}{l}\text { Effort to Preserve } \\
\text { It would require a major effort to } \\
\text { address losses in this group, } \\
\text { possibly requiring the } \\
\text { development of new preservation } \\
\text { tools or techniques. }\end{array}$ \\
\hline \multicolumn{3}{|c|}{$\begin{array}{l}\text { Examples } \\
\text { Medical scans; records of treatment and care plans; health advice and notifications; }\end{array}$} \\
\hline \multicolumn{3}{|c|}{$\begin{array}{l}\text { ‘Critically Endangered’ in the Presence of Aggravating Conditions } \\
\text { Loss of context; loss of authenticity or integrity; poor storage; lack of understanding; churn of } \\
\text { staff; significant volumes of data; significant diversity of data; ill-informed records management; } \\
\text { poorly developed transfer and integrity checking; poorly developed migration or normalizations } \\
\text { specifications; longstanding protocols or procedures that apply unsuitable paper processes to } \\
\text { digital materials; encryption }\end{array}$} \\
\hline \multicolumn{3}{|c|}{$\begin{array}{l}\text { 'Vulnerable' in the Presence of Good Practice } \\
\text { Well managed data infrastructure; preservation enabled at the point of creation; carefully } \\
\text { managed authenticity; use of persistent identifiers; well managed records management } \\
\text { processes; application of records management standards; recognition of preservation } \\
\text { requirements at highest levels; strategic investment in digital preservation; preservation } \\
\text { roadmap; participation in digital preservation community. }\end{array}$} \\
\hline \multicolumn{3}{|c|}{$\begin{array}{l}\text { Medical and hospital records were introduced to the BitList in } 2017 \text { though at that time there was } \\
\text { limited capacity to address the topic and it was simply published as 'of concern'. It would have } \\
\text { been reviewed in } 2019 \text { in any case but was independently received as a submission to the open } \\
\text { nomination process. This topic remains large and ill defined. It is useful to draw attention to the } \\
\text { scale of the digital preservation challenges which arise in hospitals and in the medical profession, } \\
\text { but it would be useful in future years to split this entry into more discrete elements which would } \\
\text { be more impactful. }\end{array}$} \\
\hline \multicolumn{3}{|c|}{$\begin{array}{l}\text { Increasing sensitivity and awareness of data protection requirements could act inadvertently as a } \\
\text { barrier to lifecycle data management. It is striking how little evidence there is of the health } \\
\text { technology companies participating in the global digital preservation community. }\end{array}$} \\
\hline 2020 Trend: Hospitals have $k$ & on nlaced under cionificant ctr & in through the pandemic, with \\
\hline
\end{tabular}




\begin{tabular}{|c|c|c|}
\hline \multicolumn{2}{|l|}{ Legacy Media Art } & \\
\hline \multicolumn{2}{|c|}{$\begin{array}{l}\text { Media art in storage or not otherwise displayed but where } \\
\text { the artists or technicians are available to support installation }\end{array}$} & \\
\hline Group: Media Art & Trend in & Consensus Decision \\
\hline Added to List: 2019 & Trend towards greater risk & Previous category: New Entry \\
\hline $\begin{array}{l}\text { Imminence of Action } \\
\text { Action is recommended } \\
\text { within three years, detailed } \\
\text { assessment within twelve } \\
\text { months }\end{array}$ & $\begin{array}{l}\text { Significance of Loss } \\
\text { The loss of tools, data or } \\
\text { services within this group } \\
\text { would impact on many } \\
\text { people and sectors. }\end{array}$ & $\begin{array}{l}\text { Effort to Preserve } \\
\text { It would require a major effort to } \\
\text { address losses in this group, } \\
\text { possibly requiring the } \\
\text { development of new preservation } \\
\text { tools or techniques. }\end{array}$ \\
\hline \multicolumn{3}{|l|}{ Examples: Media art in storage } \\
\hline \multicolumn{3}{|c|}{$\begin{array}{l}\text { Lack of documentation to enable maintenance; lack of clarity with respect to intellectual property; } \\
\text { complex interdependencies on specific hardware, software or operating systems; lack of capacity } \\
\text { in the gallery or workshop; lack of strategic investment; complex external dependencies; loss of } \\
\text { institutional memory resulting from staff churn; poor working relationship between the gallery } \\
\text { and artist/workshop; lack of conservation assessment. }\end{array}$} \\
\hline \multicolumn{3}{|c|}{$\begin{array}{l}\text { Strong documentation; clarity of preservation path and ensuing responsibilities; proven } \\
\text { preservation plan; capacity of workshop to support re-installation; capacity of gallery to conserve; } \\
\text { capacity of gallery to re-install; retention of institutional memory including archives of } \\
\text { correspondence between gallery and artist/workshop; strong and continuing working relationship } \\
\text { between the gallery and artist/workshop; regular conservation assessment. }\end{array}$} \\
\hline \multicolumn{3}{|c|}{$\begin{array}{l}2019 \text { Review: Media Art was introduced in 2017, though with particular reference to historical } \\
\text { media art which was categorised as 'critically endangered'. The jury introduced this entry to } \\
\text { ensure greater specificity in its recommendation. It is intended to represent works held in } \\
\text { galleries but no longer displayed, but where there is a continuing working relationship between } \\
\text { the gallery and the artist or workshop and reasonable expectation that support for preservation } \\
\text { could still be obtained when required. }\end{array}$} \\
\hline \multicolumn{3}{|c|}{$\begin{array}{l}\text { This entry attempts to capture a point in the lifecycle of media art where preservation risks are } \\
\text { increasing but not yet critical. There is a risk that preservation issues will not become apparent } \\
\text { until the piece is brought out of storage when being considered for loan or exhibition - often on } \\
\text { timescales that make it too late to address preservation concerns effectively. Galleries should be } \\
\text { aware that the range of data/formats/hardware/software embedded in media art can be wide } \\
\text { and vary at different speeds. }\end{array}$} \\
\hline \multicolumn{3}{|c|}{$\begin{array}{l}2020 \text { Trend: Many museums and galleries, which often rely on visitors for income, have been } \\
\text { closed for extended periods. Moreover, any form digital materials that rely on an individual;s } \\
\text { knowledge is placed at particular risk by a pandemic. In these circumstances digital materials in } \\
\text { museums and galleries records are likely to be at a greater risk than in } 2019 \text {. }\end{array}$} \\
\hline
\end{tabular}




\begin{tabular}{|c|c|c|}
\hline \multicolumn{2}{|c|}{$\begin{array}{l}\text { Massively Multiple Online Gaming Platforms } \\
\text { and Experiences }\end{array}$} & \\
\hline \multicolumn{2}{|c|}{$\begin{array}{l}\text { Massively Multiple Online Gaming is an evolving, transient } \\
\text { but significant cultural. Gameplay is referenced here } \\
\text { particularly as means of participation, along with social } \\
\text { media and in-game interaction between players. Video } \\
\text { streaming of game content, the means of viewing but not } \\
\text { participating in game play, has a septate entry. }\end{array}$} & \\
\hline Group: Gaming & Trend in 2020: & Consensus Decision \\
\hline Added to List: new entry & Trend towards greater risk & Previously: Critically Endangered \\
\hline $\begin{array}{l}\text { Imminence of Action } \\
\text { Action is recommended } \\
\text { within three years, detailed } \\
\text { assessment within one year. }\end{array}$ & $\begin{array}{l}\text { Significance of Loss } \\
\text { The loss of tools, data or } \\
\text { services within this group } \\
\text { would impact on people and } \\
\text { sectors around the world. }\end{array}$ & $\begin{array}{l}\text { Effort to Preserve } \\
\text { Loss seems likely: by the time tools } \\
\text { or techniques have been } \\
\text { developed the material will likely } \\
\text { have been lost. }\end{array}$ \\
\hline
\end{tabular}

Examples: There are numerous examples for this entry, so the example of Fortnite, a 2017 free to play online game will serve to illustrate. As Fortnite is freely accessible to play, the game is at the forefront of internet culture with over 250 million registered users as of March 2019. In addition, Fortnite's parent company, Epic Games, provides access to Unreal Engine, a software platform consisting of integrated tools for game developers, with instructional guides, game simulations and learning tools. Unreal Engine was first released in 1998 and is currently in its 4th release. At risk also is this software, its associated tools and code which is key digital evidence of MMOG evolution, learning, creativity and expression across multiple platforms (PC, console, mobile).

'Critically Endangered' in the Presence of Aggravating Conditions

Controversies around IPR; lack of offline backup; changing business model of providers; limited recognition of value of game play; over dependence on goodwill of ad-hoc community; lack of preservation know-how at service providers; dependency on bespoke hardware or interfaces.

'Vulnerable' in the Presence of Good Practice

Well documented code; IPR supportive of preservation; large and committed user community 2019 Review This is a subset of an entry made in 2017 for 'Gaming' which the Jury has split into four discrete entries. By creating this entry for Game Play, the Jury encourages greater consideration of the technical complexities which arise from preservation of software environments as well as the cultural and historic value which these games are likely to acquire. It appears that this entry is categorised as a lower risk than in 2017, but this is a function of splitting that entry.

\section{Additional Jury Comments}

The difficulty of saving game play nicely encapsulates why video recordings of (online) gameplay is important: we are never going to be able to recreate the experience of playing something like World of Warcraft or Fortnite at their peak (or at their inception, or at any other point in time). They will never have the same configuration of subscribers, to say nothing of the innumerable changes made to the software over the years, which have significantly altered how the game works and looks. Loss is inevitable, and it's already happened. The social and cultural aspects of play are incredibly important and on-screen recording is the most robust way to capture that.

2020 Trend: Online gaming has been a mainstay of social interaction during the pandemic. The risks of loss have not strictly increased, but the significance has expanded, so the consequences of loss are expanded. That is expressed here as a trend towards greater risk. 


\begin{tabular}{|c|c|c|}
\hline \multicolumn{2}{|c|}{ Master Digital Music and Sound Recordings } & \\
\hline \multicolumn{2}{|c|}{$\begin{array}{l}\text { Master recordings of music and other performance from } \\
\text { which retail products are derived, typically in multiple tracks } \\
\text { and uncompressed high-resolution sound quality }\end{array}$} & \\
\hline Group: Sound and Vision & Trend in 2020: & Consensus Decision \\
\hline Added to List: 2019 & No Change & Previous category: New Entry \\
\hline $\begin{array}{l}\text { Imminence of Action } \\
\text { Action is recommended } \\
\text { within three years, detailed } \\
\text { assessment within one year. }\end{array}$ & $\begin{array}{l}\text { Significance of Loss } \\
\text { The loss of tools, data or } \\
\text { services within this group } \\
\text { would impact on people and } \\
\text { sectors around the world. }\end{array}$ & $\begin{array}{l}\text { Effort to Preserve } \\
\text { It would require a small effort to } \\
\text { address losses in this group, } \\
\text { requiring the application of proven } \\
\text { preservation tools or techniques. }\end{array}$ \\
\hline \multicolumn{3}{|c|}{$\begin{array}{l}\text { Examples } \\
\text { Master recordings owned by music industry }\end{array}$} \\
\hline \multicolumn{3}{|c|}{$\begin{array}{l}\text { ‘Critically Endangered' in the Presence of Aggravating Conditions } \\
\text { Single point of failure; storage on old or degrading media; lack of ongoing investment in changing } \\
\text { preservation requirements; lack of capability; poor documentation; dependence on small staff }\end{array}$} \\
\hline \multicolumn{3}{|c|}{$\begin{array}{l}\text { 'Vulnerable' in the Presence of Good Practice } \\
\text { High quality storage; meticulous and consistent replication; trusted repository; preservation } \\
\text { requirement understood at executive level and funded accordingly; leadership in preservation } \\
\text { community; expert staff }\end{array}$} \\
\hline \multicolumn{3}{|c|}{$\begin{array}{l}2019 \text { Review } \\
\text { This entry has been split out of the previous entry for 'Digital Music Production and Sharing' } \\
\text { though it has overlaps with other entries. It is a separate entry to emphasise the inherent and very } \\
\text { great value of master recordings over and above those distributed, and the concomitant need for } \\
\text { active preservation. The Jury were particularly aware of the case of the 'Universal Fire' of } 2008 \\
\text { which has only recently been reported widely. }\end{array}$} \\
\hline \multicolumn{3}{|c|}{$\begin{array}{l}\text { Additional Jury Comments } \\
\text { The archival practices of the studios are typically based on value - the recordings are assumed to } \\
\text { be worth keeping. However, this means relatively low-value masters may not be transferred to } \\
\text { new media in a timely way and could be lost. There is no comprehensive deposit scheme to } \\
\text { address the long-tail of music production, and it is often unclear exactly where responsibility lies. }\end{array}$} \\
\hline
\end{tabular}




\begin{tabular}{|c|c|c|}
\hline \multicolumn{2}{|l|}{ Orphaned Works } & \\
\hline \multicolumn{2}{|c|}{$\begin{array}{l}\text { Digital materials where copyright is uncertain, disputed or } \\
\text { unknowable meaning that preservation actions are } \\
\text { constrained or prevented. }\end{array}$} & \\
\hline Group: Orphaned Works & Trend in 2020: & Consensus Decision \\
\hline Added to List: 2017 & No Change & Previous category: Endangered \\
\hline $\begin{array}{l}\text { Imminence of Action } \\
\text { Action is recommended } \\
\text { within three years, detailed } \\
\text { assessment within twelve } \\
\text { months }\end{array}$ & $\begin{array}{l}\text { Significance of Loss } \\
\text { The loss of tools, data or } \\
\text { services within this group } \\
\text { would impact on many } \\
\text { people and sectors. }\end{array}$ & $\begin{array}{l}\text { Effort to Preserve } \\
\text { It would require a major effort to } \\
\text { address losses in this group, } \\
\text { possibly requiring the } \\
\text { development of new preservation } \\
\text { tools or techniques. }\end{array}$ \\
\hline \multicolumn{3}{|c|}{$\begin{array}{l}\text { Examples } \\
\text { Photographs, music recordings, literature. A specific example is elements of The National Disc of } \\
\text { the BBC Domesday Project outside of legal deposit mandate where the copyright owner cannot be } \\
\text { traced. }\end{array}$} \\
\hline \multicolumn{3}{|c|}{$\begin{array}{l}\text { ‘Critically Endangered' in the Presence of Aggravating Conditions } \\
\text { Lack of documentation; dependencies resulting from hardware, software or media; lack of use } \\
\text { resulting in lack of priority; lack of strategic investment in digital preservation; workflows that } \\
\text { inhibit preservation of content that has not been licensed; encryption; poor storage. }\end{array}$} \\
\hline \multicolumn{3}{|c|}{$\begin{array}{l}\text { Vulnerable in the Presence of Good Practice } \\
\text { Preservation pathway enabled; proven preservation plan applied; active effort to resolve IPR } \\
\text { issues; institutional willingness to take risks for preservation. }\end{array}$} \\
\hline \multicolumn{3}{|c|}{$\begin{array}{l}2019 \text { Review } \\
\text { There is little evidence of any renewed effort to address the issue of orphaned works since } 2017 . \\
\text { Improvement to the baseline competence of the archival and library professions in their } \\
\text { understanding of copyright and the skills to preserve contents, provides a narrow basis for } \\
\text { optimism in some contexts but the scale of the challenge is likely to have grown just as quickly if } \\
\text { not more so, and aggravating conditions become more prevalent too. }\end{array}$} \\
\hline \multicolumn{3}{|c|}{$\begin{array}{l}\text { Additional Jury Comments } \\
\text { The Jury would encourage organizations to take a risk-based approach which would help them } \\
\text { preserve collections. Copyright infringements are only likely to become a significant issue in the } \\
\text { context of access, and in most cases the likelihood of any specific action is small. Preservation } \\
\text { needs to be presented as a social good, one without which copyright holders would simply be } \\
\text { unable to benefit from the property rights they seek to protect. }\end{array}$} \\
\hline
\end{tabular}




\begin{tabular}{|c|c|c|}
\hline \multicolumn{2}{|l|}{ PDF other than PDF/A } & \\
\hline \multicolumn{2}{|c|}{$\begin{array}{l}\text { Documents presented in PDF (Portable Document Format) } \\
\text { format (ISO 32000:1 and ISO 32000:2) and other data } \\
\text { wrapped inside them, other than PDF/A but including all } \\
\text { other variants and versions. }\end{array}$} & \\
\hline Grou & & onsensus Decision \\
\hline Added to & No & revious category: Of Concern \\
\hline $\begin{array}{l}\text { Imminence of Action } \\
\text { Action is recommended } \\
\text { within five years, detailed } \\
\text { assessment within three } \\
\text { years. }\end{array}$ & $\begin{array}{l}\text { Significance of Loss } \\
\text { The loss of tools, data or } \\
\text { services within this group } \\
\text { would impact on people and } \\
\text { sectors around the world.. }\end{array}$ & $\begin{array}{l}\text { Effort to Preserve } \\
\text { It would require a small effort to } \\
\text { address losses in this group, } \\
\text { requiring the application of proven } \\
\text { preservation tools or techniques. }\end{array}$ \\
\hline \multicolumn{3}{|c|}{$\begin{array}{l}\text { Examples } \\
\text { PDF } 1.1,1.2,1.3,1.4 \text { (excluding PDF/A as a subset), 1.5, 1.6, 1.7 and 2.0. PDF/X and PDF/E }\end{array}$} \\
\hline \multicolumn{3}{|c|}{$\begin{array}{l}\text { ‘Critically Endangered' in the Presence of Aggravating Conditions } \\
\text { Loss of context; loss of authenticity or integrity; external dependencies; poor storage; lack of } \\
\text { understanding; significant diversity of data; poorly developed digitization specifications; lack of } \\
\text { integrity checking; poorly developed migration or normalizations specifications; lack of virus } \\
\text { control; poor storage or replication; lack of validation at the point of creation; encryption. }\end{array}$} \\
\hline \multicolumn{3}{|c|}{$\begin{array}{l}\text { 'Vulnerable' in the Presence of Good Practice } \\
\text { Well managed data infrastructure; preservation planning; authenticity managed; use of persistent } \\
\text { identifiers; reduction of dependencies; application of records management standards; recognition } \\
\text { of preservation requirements beyond formats; strategic investment in digital preservation; } \\
\text { preservation roadmap; participation in digital preservation community; format validation. }\end{array}$} \\
\hline \multicolumn{3}{|c|}{$\begin{array}{l}2019 \text { Review } \\
\text { The judges have introduced this entry as a subset of a previous entry for 'PDF', emphasizing the } \\
\text { different threats faced by different types of PDF. PDF/A explicitly reduces dependencies and thus } \\
\text { curtails preservation risks for certain types of content: PDFs of other types do not. PDF and PDF/A } \\
\text { have sometimes been misunderstood as a generic solution to digital preservation requirements. } \\
\text { In the eyes of the judges it can only offer a preservation solution when embedded within a wider } \\
\text { preservation infrastructure. }\end{array}$} \\
\hline \multicolumn{3}{|c|}{$\begin{array}{l}\text { Additional Jury Comments } \\
\text { See also: } \\
\text { Fanning, B (2017) Preserving with PF/A (Second Edition), DPC Technology Watch Report 17-01 } \\
\text { online at http://dx.doi.org/10.7207/twr17-01 }\end{array}$} \\
\hline
\end{tabular}




\begin{tabular}{|c|c|c|}
\hline \multicolumn{2}{|c|}{ Premium or institutional social media services } & \\
\hline \multicolumn{2}{|c|}{$\begin{array}{l}\text { Commercial social media services which are based on a } \\
\text { costed subscription and contract. }\end{array}$} & \\
\hline Group: & Tre & onsensus Decision \\
\hline Added to List: 2019 & No & revious category: New Entry \\
\hline $\begin{array}{l}\text { Imminence of Action } \\
\text { Action is recommended } \\
\text { within three years, detailed } \\
\text { assessment within twelve } \\
\text { months }\end{array}$ & $\begin{array}{l}\text { Significance of Loss } \\
\text { The loss of tools, data or } \\
\text { services within this group } \\
\text { would impact on many } \\
\text { people and sectors. }\end{array}$ & $\begin{array}{l}\text { Effort to Preserve } \\
\text { It would require a major effort to } \\
\text { address losses in this group, } \\
\text { possibly requiring the } \\
\text { development of new preservation } \\
\text { tools or techniques. }\end{array}$ \\
\hline \multicolumn{3}{|c|}{$\begin{array}{l}\text { Examples } \\
\text { Premium versions of Vimeo, Flickr, Yammer, Slack, Mircosoft Teams and others. }\end{array}$} \\
\hline \multicolumn{3}{|c|}{$\begin{array}{l}\text { 'Critically Endangered' in the Presence of Aggravating Conditions } \\
\text { Unstable business models and pricing schedules from providers; lack of export functionality; } \\
\text { unstable terms and conditions; lack of onsite copy of key media; lack of strategic plan for IT } \\
\text { provision; confusion on IPR; asymmetrical contract arrangements; conflating preservation and } \\
\text { access. }\end{array}$} \\
\hline \multicolumn{3}{|c|}{$\begin{array}{l}\text { 'Vulnerable' in the Presence of Good Practice } \\
\text { Offline back up for key media; fit to preservation and records management plan; strategic } \\
\text { roadmap for adoption of social media; }\end{array}$} \\
\hline \multicolumn{3}{|c|}{$\begin{array}{l}2019 \text { Review } \\
\text { The judges have introduced this entry as a subset of a previous entry, emphasizing the different } \\
\text { threats faced by services that are 'paid-for' versus 'free-at-the-point-of-use'. Both depend on the } \\
\text { business model of the vendor and the terms and conditions which they impose. For this group, } \\
\text { the business model and sustainability are more obvious and contracts may be enforceable more } \\
\text { readily. Moreover, because these services have a slightly higher barrier to entry they may be } \\
\text { favoured by agencies better able to respond to closure or loss. }\end{array}$} \\
\hline \multicolumn{3}{|c|}{$\begin{array}{l}\text { Additional Jury Comments } \\
\text { Traditional web archiving can be employed where the user pays for a service but content is } \\
\text { ultimately publicly available (such as Flickr) where the user may pay for a full account to be able to } \\
\text { host more photos publicly. But much is unclear about how to preserve internal social media / } \\
\text { closed networks that web archiving can't get to or existing tools don't cover. The growth in use of } \\
\text { these products for communication and social networking leads us to think this is endangered } \\
\text { rather than vulnerable. It's possible that existing tools could be modified to tackle some of these } \\
\text { closed networks but that is likely to require some investments, perhaps related to corporate } \\
\text { records in some cases (thinking about internal Slacks, for instance), and more education about the } \\
\text { importance of preserving this material and not trusting the publishing platforms to host the } \\
\text { content forever. }\end{array}$} \\
\hline
\end{tabular}




\begin{tabular}{|c|c|c|}
\hline \multicolumn{2}{|c|}{ Pre-Production TV and Movie Materials } & \\
\hline \multicolumn{2}{|c|}{$\begin{array}{l}\text { Digital records of the creative and production process for } \\
\text { film and television, such as initial designs, screenplay and } \\
\text { script, on set still photography, rushes or out-takes that are } \\
\text { not included in the final production and therefore not } \\
\text { available to on-air broadcast archives or film libraries }\end{array}$} & \\
\hline Group: Sound and Vision & Trend in 2020: & onsensus Decision \\
\hline Added to List: 2017 & NoC & Previous category: Of Concern \\
\hline $\begin{array}{l}\text { Imminence of Action } \\
\text { Action is recommended } \\
\text { within three years, detailed } \\
\text { assessment within twelve } \\
\text { months }\end{array}$ & $\begin{array}{l}\text { Significance of Loss } \\
\text { The loss of tools, data or } \\
\text { services within this group } \\
\text { would impact on many } \\
\text { people and sectors. }\end{array}$ & $\begin{array}{l}\text { Effort to Preserve } \\
\text { It would require a major effort to } \\
\text { address losses in this group, } \\
\text { possibly requiring the } \\
\text { development of new preservation } \\
\text { tools or techniques. }\end{array}$ \\
\hline \multicolumn{3}{|c|}{$\begin{array}{l}\text { Examples } \\
\text { TV and Movie production archives in digital form; outputs of script management software; drafts } \\
\text { of screenplay; continuity photography; costume design; set design; lighting and sound design. }\end{array}$} \\
\hline \multicolumn{3}{|c|}{$\begin{array}{l}\text { ‘Critically Endangered' in the Presence of Aggravating Conditions } \\
\text { Lack of custodial responsibility; confusion over intellectual property rights; lack of appraisal; lack } \\
\text { of recognition of preservation at executive level; }\end{array}$} \\
\hline \multicolumn{3}{|c|}{$\begin{array}{l}\text { 'Vulnerable' in the Presence of Good Practice } \\
\text { Preservation responsibility understood and acted upon; preservation infrastructure and planning } \\
\text { for key items; access and use of collections to inform subsequent productions }\end{array}$} \\
\hline \multicolumn{3}{|c|}{$\begin{array}{l}2019 \text { Review } \\
\text { This entry was first proposed in } 2017 \text { and noted as being 'of concern', though the Jury did not } \\
\text { have the capacity to assess the entry thoroughly. Additional expertise has been recruited to the } \\
\text { Jury this year to help with the assessment. }\end{array}$} \\
\hline \multicolumn{3}{|c|}{$\begin{array}{l}\text { Additional Jury Comments } \\
\text { These materials are not being collected in any coherent way and will be lost as they are not valued } \\
\text { by production companies, the space needed to hold them is costly and the expertise needed to } \\
\text { catalogue and collect them is lacking. In short, nobody really cares. This is not primarily a technical } \\
\text { problem and advocacy is needed urgently. }\end{array}$} \\
\hline
\end{tabular}




\begin{tabular}{|c|c|c|}
\hline \multicolumn{2}{|c|}{$\begin{array}{l}\text { Published Research Data Appended to Journal } \\
\text { Articles }\end{array}$} & \\
\hline \multicolumn{2}{|c|}{$\begin{array}{l}\text { Closed research data sets produced and documented in } \\
\text { accordance with good practice and simply appended to a } \\
\text { journal article or transferred to a repository which does not } \\
\text { have sufficient subject-matter expertise or funding } \\
\text { commitment to ensure reliable or ongoing preservation for } \\
\text { the long term. }\end{array}$} & \\
\hline Group: Rese & & onsensus Decision \\
\hline Added to Li & & revious category: New Entry \\
\hline years. & & $\begin{array}{l}\text { Effort to Preserve } \\
\text { It would require a small effort to } \\
\text { prevent losses in this group, such } \\
\text { as the deployment of proven } \\
\text { preservation tools or techniques. }\end{array}$ \\
\hline \multicolumn{3}{|c|}{$\begin{array}{l}\text { Examples } \\
\text { Data sets added to papers in repositories that are designed primarily for papers; electronic } \\
\text { journals offering data sets without obvious preservation capacity; institutional repositories } \\
\text { servicing highly complex scientific data sets with insufficient subject-matter expertise. }\end{array}$} \\
\hline \multicolumn{3}{|c|}{$\begin{array}{l}\text { ‘Critically Endangered' in the Presence of Aggravating Conditions } \\
\text { Unstable funding or revenues; poorly designed migration or normalization processes; poorly } \\
\text { formed ingest and quality assurance procedures; rapid churn of staff; incoherent patterns of } \\
\text { subject matter; lack of domain knowledge; no or very small numbers of users; weak or absent } \\
\text { collecting policy; deposit to ensure minimal compliance with funder mandate; limited or } \\
\text { dysfunctional data management planning. }\end{array}$} \\
\hline \multicolumn{3}{|c|}{$\begin{array}{l}\text { 'Vulnerable' in the Presence of Good Practice } \\
\text { Clear preservation planning; repository development roadmap; ability to transfer collections or } \\
\text { share metadata with subject repositories or portals; strong user base; demonstrable re-use of } \\
\text { data; clear collecting policy; data management planning early in data lifecycle. }\end{array}$} \\
\hline \multicolumn{3}{|c|}{$\begin{array}{l}2019 \text { Review } \\
\text { Research data has been an entry in the BitList since } 2017 \text { so the Jury this year has tried to spell out } \\
\text { the different complexities that arise in the preservation of research outputs more generally. This } \\
\text { entry draws attention to services which take upon themselves commitments to preserve research } \\
\text { data, but which may not be able to deliver those promises through lack of capability. }\end{array}$} \\
\hline \multicolumn{3}{|c|}{$\begin{array}{l}\text { Additional Jury Comments } \\
\text { Research data is complex and has specific requirements for documentation which may only be } \\
\text { known to subject matter experts. However well intended, it is risky for institutions to attempt to } \\
\text { replicate that level of expertise across all the domains within the institution, and it can be hard for } \\
\text { smaller publishers to make commitments to sustain data in the long term. }\end{array}$} \\
\hline
\end{tabular}




\begin{tabular}{|c|c|c|}
\hline \multicolumn{2}{|c|}{$\begin{array}{l}\text { Recordings of video game play uploaded to } \\
\text { online platforms }\end{array}$} & \\
\hline \multicolumn{2}{|c|}{$\begin{array}{l}\text { Recordings of game playing and e-sports that show how } \\
\text { games are experienced and played, especially multi-user } \\
\text { online games and tournaments. }\end{array}$} & \\
\hline Group: Gaming & Tren & Consensus Decision \\
\hline Added to List: 20 & & \\
\hline $\begin{array}{l}\text { Imminence of Action } \\
\text { Action is recommended } \\
\text { within three years, detailed } \\
\text { assessment within one year. }\end{array}$ & $\begin{array}{l}\text { Significance of Loss } \\
\text { The loss of tools, data or } \\
\text { services within this group } \\
\text { would impact on people and } \\
\text { sectors around the world. }\end{array}$ & $\begin{array}{l}\text { Effort to Preserve } \\
\text { It would require a major effort to } \\
\text { prevent losses in this group, } \\
\text { possibly requiring the } \\
\text { development of new preservation } \\
\text { tools or techniques. }\end{array}$ \\
\hline \multicolumn{3}{|c|}{$\begin{array}{l}\text { Examples } \\
\text { Material uploaded to Amazon Twitch, game channels on YouTube and other playback services }\end{array}$} \\
\hline \multicolumn{3}{|c|}{$\begin{array}{l}\text { ‘Critically Endangered' in the Presence of Aggravating Conditions } \\
\text { Controversies around intellectual property rights; lack of offline backup; changing business model } \\
\text { of providers; limited recognition of cultural and historic value of game play; over dependence on } \\
\text { goodwill subsidy of ad-hoc community; lack of preservation know-how at service providers; } \\
\text { dependency on bespoke hardware or interfaces. }\end{array}$} \\
\hline \multicolumn{3}{|c|}{$\begin{array}{l}\text { 'Vulnerable' in the Presence of Good Practice } \\
\text { Offline backup; managed intellectual property rights; players and audiences invested in data }\end{array}$} \\
\hline \multicolumn{3}{|c|}{$\begin{array}{l}2019 \text { Review } \\
\text { This is a subset of an entry made in } 2017 \text { for 'Gaming' which the Jury has decided to split into four } \\
\text { more discrete entries. It has overlaps with an entry on Consumer Social Media except this } \\
\text { category specifically draws attention to gaming and e-sports. It is a subset of both. By including as } \\
\text { a separate entry,the Jury encourages greater consideration of the cultural and historic value } \\
\text { which such recordings are likely to acquire as well as the technical and economic challenges to } \\
\text { preservation. It also notes that this entry is categorised as a lower risk than the entry in 2017: but } \\
\text { this is a function of splitting that entry into components. }\end{array}$} \\
\hline \multicolumn{3}{|c|}{$\begin{array}{l}\text { Additional Jury Comments } \\
\text { Vulnerable is an appropriate classification. The content is not particularly distinctive in technical } \\
\text { terms but there are aggravating circumstances, namely an almost complete reliance on } \\
\text { commercial third parties (Google/YouTube and Amazon/Twitch) for the infrastructure around } \\
\text { video capture and hosting. Copyright claims on video content by publishers such as Nintendo - } \\
\text { while less prevalent now than a few years ago - also complicate things. The significance of loss } \\
\text { here is high because recordings, including commentary, and onscreen interactions with other } \\
\text { players, seem likely to be the best way of preserving the experience of playing certain games at } \\
\text { certain times. We are familiar with the challenges of preserving video, but we need to think about } \\
\text { how established approaches will work in the context of the aggravating circumstances outlined } \\
\text { above. There is a degree of urgency associated with working out how (legally and technically) } \\
\text { preserving the materials that they hold may be preserved. }\end{array}$} \\
\hline
\end{tabular}




\begin{tabular}{|c|c|c|}
\hline Records of Quasi Non- & overnmental Agencies & \\
\hline $\begin{array}{l}\text { Records from agencies at arn } \\
\text { whether locally, nationally o } \\
\text { required to maintain archive } \\
\text { transparency, sometimes for } \\
\text { sometimes in diverse and co } \\
\text { they are at arm's length to g } \\
\text { 'ALEO' (Arms-Length Executi } \\
\text { capacity to meet complex dig } \\
\text { that arise, nor be able to dep }\end{array}$ & $\begin{array}{l}\text { s-length to government } \\
\text { nternationally. They may be } \\
\text { for the purposes of } \\
\text { xtended periods, and } \\
\text { plicated forms. But because } \\
\text { jernment but the 'QuaNGO' or } \\
\text { Organization) may lack the } \\
\text { tal preservation requirements } \\
\text { sit in the government archive. }\end{array}$ & \\
\hline Group: Public Records & Trend in 2020: & Consensus Decision \\
\hline Added to List: 2019 & No Change & Previous category: 2019 \\
\hline $\begin{array}{l}\text { Imminence of Action } \\
\text { Action is recommended } \\
\text { within three years, detailed } \\
\text { assessment within one year. }\end{array}$ & $\begin{array}{l}\text { Significance of Loss } \\
\text { The loss of tools, data or } \\
\text { services within this group } \\
\text { would impact on many } \\
\text { people and sectors. }\end{array}$ & $\begin{array}{l}\text { Effort to Preserve } \\
\text { It would require a major effort to } \\
\text { prevent losses in this group, } \\
\text { possibly requiring the } \\
\text { development of new preservation } \\
\text { tools or techniques. }\end{array}$ \\
\hline $\begin{array}{l}\text { Examples } \\
\text { Records of non-executive sta } \\
\text { regulators; public audit servi } \\
\text { semi-autonomous public age } \\
\text { owned companies. }\end{array}$ & cies; sovereign wealth funds; & $\begin{array}{l}\text { or leisure trusts; industry or public } \\
\text { stment agencies; autonomous and } \\
\text { blic/private partnerships; publicly }\end{array}$ \\
\hline $\begin{array}{l}\text { ‘Critically Endangered' in the } \\
\text { Lack of preservation infrastrc } \\
\text { integrity; Long-lived business } \\
\text { diversity of data; poorly deve } \\
\text { poorly developed migration } \\
\text { procedures that apply unsuit } \\
\text { instability; lack of sustained } \mathrm{f}\end{array}$ & $\begin{array}{l}\text { Presence of Aggravating Condit } \\
\text { ture; conflation of backup with } \\
\text { orocesses; poor storage; churn } \\
\text { oped digitization specifications; } \\
\text { normalizations specifications; } \\
\text { ble paper processes to digital m } \\
\text { nding. }\end{array}$ & $\begin{array}{l}\text { ions } \\
\text { preservation; loss of authenticity or } \\
\text { f staff; significant volumes or } \\
\text { ill-informed records management; } \\
\text { ongstanding protocols or } \\
\text { aterials; encryption; political }\end{array}$ \\
\hline $\begin{array}{l}\text { Vulnerable in the Presence } 0 \\
\text { Well managed data infrastru } \\
\text { managed authenticity; use of } \\
\text { management processes; app } \\
\text { preservation requirements a } \\
\text { preservation roadmap; partic }\end{array}$ & $\begin{array}{l}\text { Good Practice } \\
\text { ure; preservation enabled at th } \\
\text { oersistent identifiers; finding aic } \\
\text { cation of records management } \\
\text { highest levels; strategic investm } \\
\text { pation in digital preservation co }\end{array}$ & $\begin{array}{l}\text { point of creation; carefully } \\
\text { s; well managed records } \\
\text { tandards; recognition of } \\
\text { ent in digital preservation; } \\
\text { nmunity. }\end{array}$ \\
\hline $\begin{array}{l}2019 \text { Review } \\
\text { This is a new entry which the } \\
\text { of long duration from Local } \mathrm{C} \\
\text { allow greater concentration }\end{array}$ & the challenges that these diffe & $\begin{array}{l}\text { an earlier larger entry for 'Records } \\
\text { Agencies'. The split is intended to } \\
\text { rent types of agency face. }\end{array}$ \\
\hline $\begin{array}{l}\text { Additional Jury Comments } \\
\text { Although the split draws atte } \\
\text { further subdivided into legall } \\
\text { our digital preservation of so } \\
\text { records management is clear } \\
\text { to match the requirement, th }\end{array}$ & $\begin{array}{l}\text { tion to the different pressures } f \\
\text { required public records and ad } \\
\text { ety. The classification assumes } \\
\text { defined, but if this is not the ca } \\
\text { the risk goes up. }\end{array}$ & $\begin{array}{l}\text { aced by QuaNGO's it could be } \\
\text { litional information that may enrich } \\
\text { hat the roles and requirement for } \\
\text { se or there is inadequate resource }\end{array}$ \\
\hline
\end{tabular}




\begin{tabular}{|c|c|c|}
\hline \multicolumn{2}{|c|}{ Semi-Published Research Data } & \\
\hline \multicolumn{2}{|c|}{$\begin{array}{l}\text { Data sets produced in the course of research and shared } \\
\text { informally between researchers such as by posting to a } \\
\text { website or portal but without preservation capability or } \\
\text { commitment. Typically the data remains in the hands of the } \\
\text { researchers who have the job of maintaining it. }\end{array}$} & \\
\hline Group: Research Outputs & Trend in 2020: & Consensus Decision \\
\hline Added to List: 2019 & No Change & Previous category: New Entry \\
\hline $\begin{array}{l}\text { Imminence of Action } \\
\text { Action is recommended } \\
\text { within five years, detailed } \\
\text { assessment within three } \\
\text { years. }\end{array}$ & $\begin{array}{l}\text { Significance of Loss } \\
\text { The loss of tools, data or } \\
\text { services within this group } \\
\text { would impact on people and } \\
\text { sectors around the world. }\end{array}$ & $\begin{array}{l}\text { Effort to Preserve } \\
\text { It would require a major effort to } \\
\text { prevent losses in this group, such } \\
\text { as the development of new } \\
\text { preservation tools or techniques. }\end{array}$ \\
\hline \multicolumn{3}{|c|}{$\begin{array}{l}\text { Examples } \\
\text { Departmental webservers; project wikis; GitHub repositories }\end{array}$} \\
\hline \multicolumn{3}{|c|}{$\begin{array}{l}\text { 'Critically Endangered' in the Presence of Aggravating Conditions } \\
\text { Originating researcher no longer active or changed research focus; staff on temporary contracts; } \\
\text { dependence on single student or staff member; weak or fluid institutional commitment to subject } \\
\text { matter; weak institutional commitment to data sharing; complicated or contested intellectual } \\
\text { property; encryption; limited or dysfunctional data management planning. }\end{array}$} \\
\hline \multicolumn{3}{|c|}{$\begin{array}{l}\text { Vulnerable in the Presence of Good Practice } \\
\text { Data in preparation for transfer to specialist repository; robust data management planning; } \\
\text { documented and managed professionally; }\end{array}$} \\
\hline \multicolumn{3}{|c|}{$\begin{array}{l}2019 \text { Review } \\
\text { Research data has been an entry in the BitList since } 2017 \text { so the Jury this year has tried to spell out } \\
\text { the different complexities that arise in the preservation of research outputs more generally. This } \\
\text { entry represents 'self-help' data sharing which is to be encouraged as a means to facilitate open } \\
\text { science but shouldn't be confused with long-term preservation. }\end{array}$} \\
\hline \multicolumn{3}{|c|}{$\begin{array}{l}\text { Additional Jury Comments } \\
\text { Research data is complex and has specific requirements for documentation which may only be } \\
\text { known to subject matter experts. However, data creators are not necessarily well placed to } \\
\text { sustain data in the long term. }\end{array}$} \\
\hline
\end{tabular}




\begin{tabular}{|c|c|c|}
\hline \multicolumn{2}{|l|}{ Video files } & \\
\hline \multicolumn{2}{|c|}{$\begin{array}{l}\text { Video files in any format containing moving picture and } \\
\text { sound recordings }\end{array}$} & \\
\hline Group: Sound and Vision & Trend in 2020: & Consensus Decision \\
\hline Added to List: 2019 & No Change & Previous category: New Entry \\
\hline $\begin{array}{l}\text { Imminence of Action } \\
\text { Action is recommended } \\
\text { within five years, detailed } \\
\text { assessment within three } \\
\text { years. }\end{array}$ & $\begin{array}{l}\text { Significance of Loss } \\
\text { The loss of tools, data or } \\
\text { services within this group } \\
\text { would impact on people and } \\
\text { sectors around the world. }\end{array}$ & $\begin{array}{l}\text { Effort to Preserve } \\
\text { It would require a small effort to } \\
\text { prevent losses in this group, such } \\
\text { as the deployment of proven } \\
\text { preservation tools or techniques. }\end{array}$ \\
\hline \multicolumn{3}{|l|}{ Examples } \\
\hline \multicolumn{3}{|c|}{$\begin{array}{l}\text { 'Critically Endangered' in the Presence of Aggravating Conditions } \\
\text { Lack of replication; encryption; digital rights management; proliferation of file formats; weak or } \\
\text { non-existent technical documentation; lack of preservation capability or commitment; poorly } \\
\text { managed or digitisation processes or QA. }\end{array}$} \\
\hline \multicolumn{3}{|c|}{$\begin{array}{l}\text { Vulnerable in the Presence of Good Practice } \\
\text { Effective replication; normalization of file formats; strong technical documentation; preservation } \\
\text { pathway; good descriptive cataloguing; trusted repository. }\end{array}$} \\
\hline \multicolumn{3}{|c|}{$\begin{array}{l}2019 \text { Review } \\
\text { This is a new entry submitted through the open nomination process. There are connections } \\
\text { between this entry and others relating to social media but has been included as its own entry } \\
\text { because the Jury wanted to emphasize the issues of video preservation that pertain to offline } \\
\text { recording, whether from broadcast, film industry, institutional and private collections too. }\end{array}$} \\
\hline \multicolumn{3}{|c|}{$\begin{array}{l}\text { Additional Jury Comments } \\
\text { There are simply too many formats and too many standards, but the FFMPEG project and its } \\
\text { related tools have significantly mitigated the technical risk to most video files. This enables a } \\
\text { practitioners to transform the vast majority of file formats to safer preservation formats while } \\
\text { retaining significant properties. However, technical risk is only one of the factors. There needs to } \\
\text { be institutional engagement with audio-visual data as a priority. The issue then becomes one of } \\
\text { identifying the organizations responsible and, constrained by the cost to store video data, making } \\
\text { effective selection decisions. }\end{array}$} \\
\hline
\end{tabular}




\section{Critically Endangered}

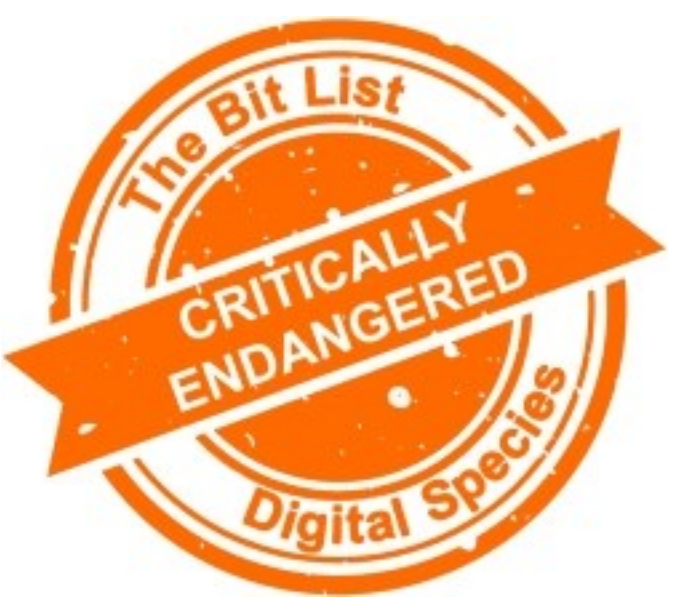

Digital materials are listed Critically Endangered when they face material technical challenges to preservation, there are no agencies responsible for them or those agencies are unwilling or unable to meet preservation needs.

This classification includes Endangered materials in the presence of aggravating conditions and instances of Practically Extinct materials that have been identified but not fully recovered. 


\begin{tabular}{|c|c|c|}
\hline \multicolumn{2}{|c|}{ Adobe Flash animations and interactive applets } & \\
\hline \multicolumn{2}{|c|}{$\begin{array}{l}\text { Animations, games, and other interactive applets created } \\
\text { with Macromedia Adobe Flash, along with their } \\
\text { accompanying websites. These are primarily .swf files, but } \\
\text { they can also include networked collections of .swf files and } \\
\text { external assets, as well as the web pages where they are } \\
\text { displayed. }\end{array}$} & \\
\hline Group: Web & Trend in 2020: & Consensus Decision \\
\hline Added to List: & Trend towards $q$ & Previous category: New Entry \\
\hline $\begin{array}{l}\text { Imminence of Action } \\
\text { Action is recommended } \\
\text { within } 12 \text { months detailed } \\
\text { assessment is now a priority }\end{array}$ & $\begin{array}{l}\text { Significance of Loss } \\
\text { The loss of tools, data or } \\
\text { services within this group } \\
\text { would impact on people and } \\
\text { sectors around the world. }\end{array}$ & $\begin{array}{l}\text { Effort to Preserve } \\
\text { It would require a major effort to } \\
\text { prevent losses in this group, such } \\
\text { as the development of new } \\
\text { preservation tools or techniques. }\end{array}$ \\
\hline \multicolumn{3}{|c|}{$\begin{array}{l}\text { Examples } \\
\text { Flash based games; Flash cartoons; Flash interactives }\end{array}$} \\
\hline \multicolumn{3}{|c|}{$\begin{array}{l}\text { 'Practically Extinct' in the Presence of Aggravating Conditions } \\
\text { Dependence on older (unpatched) versions of Flash Player; lack of migration pathway to HTML5 } \\
\text { or cognate technology; lack of capacity or motivation to export; execution in older browsers. }\end{array}$} \\
\hline \multicolumn{3}{|c|}{$\begin{array}{l}\text { 'Endangered' in the Presence of Good Practice } \\
\text { Migration plan initiated; supported in multiple browsers; security vetted }\end{array}$} \\
\hline \multicolumn{3}{|c|}{$\begin{array}{l}2019 \text { Review } \\
\text { This is a new entry received from the Open submission process and reviewed by the Jury. Flash } \\
\text { animations and applets was a mainstay of interactive web design from the late } 1990 \text { 's. Flash } \\
\text { animations and interactives are created using tools supplied by the Adobe of the same name. } \\
\text { Although Flash enables the development of sophisticated interaction at low cost over the web, it } \\
\text { has had a chequered history in terms of browser support and has been plagued by security } \\
\text { concerns. It is due to be retired by December } 2020 \text { and publishers are being encouraged to } \\
\text { migrate to alternative formats. }\end{array}$} \\
\hline \multicolumn{3}{|c|}{$\begin{array}{l}\text { Additional Jury Comments } \\
\text { Flash represents a significant amount of the creativity of websites in the early } 2000 \text { 's including } \\
\text { net-based art and cartoons. Extinction is imminent for flash viewers: web archives will need to } \\
\text { consider if it is possible to preserve interaction in newer browsers, or rely on a much more highly } \\
\text { selective WebRecorder approach. }\end{array}$} \\
\hline \multicolumn{3}{|c|}{$\begin{array}{l}2020 \text { Trend: Adobe has indicated for some time the withdrawal of support to Flash Animation } \\
\text { which is due for retiral in December 2020. Actions to retrieve Flash Animation are therefore more } \\
\text { urgent now than in } 2019 \text {. }\end{array}$} \\
\hline
\end{tabular}




\begin{tabular}{|c|c|c|}
\hline \multicolumn{2}{|c|}{$\begin{array}{l}\text { Born Digital Images Held Offline on Portable } \\
\text { Storage Devices }\end{array}$} & . \\
\hline \multicolumn{3}{|c|}{$\begin{array}{l}\text { Digital images with no analogue equivalent stored offline on } \\
\text { portable storage devices or on hard disks, especially where } \\
\text { there is no refreshment plan or no replication. }\end{array}$} \\
\hline Group: Portable Media & Trend in 2020: & Consensus Decision \\
\hline Added to List: 2019 & No Change & Previously: Critically Endangered \\
\hline $\begin{array}{l}\text { Imminence of Action } \\
\text { Action is recommended } \\
\text { within three years, } \\
\text { assessment in twelve } \\
\text { months. }\end{array}$ & $\begin{array}{l}\text { Significance of Loss } \\
\text { The loss of tools, data or } \\
\text { services within this group } \\
\text { would impact on many } \\
\text { people and sectors. }\end{array}$ & $\begin{array}{l}\text { Effort to Preserve } \\
\text { It would require a major effort to } \\
\text { prevent losses in this group, such } \\
\text { as the development of new } \\
\text { preservation tools or techniques. }\end{array}$ \\
\hline \multicolumn{3}{|c|}{$\begin{array}{l}\text { Examples } \\
\text { Offline photo collections on CD or DVD }\end{array}$} \\
\hline \multicolumn{3}{|c|}{$\begin{array}{l}\text { 'Practically Extinct' in the Presence of Aggravating Conditions } \\
\text { dependence on obsolete or proprietary formats or processes; no replication; no archival function; } \\
\text { lack of preservation capacity; lack of skills; single points of failure; lack of clear stewardship or } \\
\text { sense of ownership old or obsolete media; lack of refreshment plan; lack or loss of } \\
\text { documentation; overabundance; primary storage is camera or phone }\end{array}$} \\
\hline \multicolumn{3}{|c|}{$\begin{array}{l}\text { 'Endangered' in the Presence of Good Practice } \\
\text { Refreshment pathway; routine error checking; replication; resource scaled to size of collection; } \\
\text { preservation responsibility understood; }\end{array}$} \\
\hline \multicolumn{3}{|c|}{$\begin{array}{l}2019 \text { Review } \\
\text { This entry was originally submitted in } 2017 \text { and remains on the list though with relationships to a } \\
\text { number of other entries, especially in relation to different kinds of portable media. }\end{array}$} \\
\hline \multicolumn{3}{|c|}{$\begin{array}{l}\text { Additional Jury Comments } \\
\text { Highly dependent on who is looking after the offline media but more difficult over time. There is a } \\
\text { lack of granularity in the definition of media so only generic advice is possible such as "make sure } \\
\text { you're moving your data to new forms of storage every } 5 \text {-10 years". It would be possible to split } \\
\text { into different storage media (maybe } 100 \text { items long). }\end{array}$} \\
\hline
\end{tabular}




\begin{tabular}{|c|c|c|}
\hline \multicolumn{2}{|c|}{$\begin{array}{l}\text { Community-generated Content in Arts and } \\
\text { Heritage }\end{array}$} & \\
\hline \multicolumn{2}{|c|}{$\begin{array}{l}\text { Digital materials produced and shared in and by ad-hoc } \\
\text { community art and heritage projects, typically through } \\
\text { digitization, where the creation of digital materials was a } \\
\text { significant purpose of the initiative. }\end{array}$} & \\
\hline Grol & & sensus Decision \\
\hline Adde & & revious category: New Entry \\
\hline $\begin{array}{l}\text { tion } \\
\text { nended } \\
\text { s, detailed } \\
\text { w a priority }\end{array}$ & & \\
\hline \multicolumn{3}{|c|}{$\begin{array}{l}\text { Examples } \\
\text { Locally organised programmes associated with public remembrance and celebration such as } \\
\text { World War One centennial commemorations; City of Culture; Olympic Games; World Cup }\end{array}$} \\
\hline \multicolumn{3}{|c|}{$\begin{array}{l}\text { 'Practically Extinct' in the Presence of Aggravating Conditions } \\
\text { Poor documentation; lack of replication; lack of continuity funding; lack of residual mechanism. } \\
\text { dependence on small number of volunteers, lack of preservation mandate; lack of preservation } \\
\text { thinking at the outset; failure of digital legacy planning; conflation of backup with preservation; } \\
\text { conflation of access and preservation; inaccessible to web archiving }\end{array}$} \\
\hline \multicolumn{3}{|c|}{$\begin{array}{l}\text { 'Endangered' in the Presence of Good Practice } \\
\text { Residual archive with residual funding able to receive and support collections; strict adherence to } \\
\text { digitization guidelines; quality assurance; active user community; intellectual property managed } \\
\text { to enable preservation. }\end{array}$} \\
\hline \multicolumn{3}{|c|}{$\begin{array}{l}2019 \text { Review } \\
\text { The jury created this entry in } 2019 \text { as a subset of 'Community Archives and Community-Generated } \\
\text { Content' which has been split into two to provide greater specificity in recommendations. }\end{array}$} \\
\hline \multicolumn{3}{|c|}{$\begin{array}{l}\text { Additional Jury Comments } \\
\text { Local archives address these collections on an ad hoc basis. This entry has a high 'star quality' } \\
\text { because it provides cultural insights into parts of society not addressed by collecting policies with } \\
\text { a focus on the famous. Difficult to state whether national or international impact since it largely } \\
\text { depends on the content and how widely it is used. I think this also depends on the identity group } \\
\text { represented by the community group such as events around Black History Month. Loss seems } \\
\text { likely because of the precarity of the funding streams, of lack thereof, for these projects. Once } \\
\text { digitisation has been carried out, many projects do not know what to do with them or have the } \\
\text { means to make them accessible. Often a lack of understanding of copyright is barrier to sharing. }\end{array}$} \\
\hline \multicolumn{3}{|c|}{$\begin{array}{l}2020 \text { Trend: Community art and heritage groups, which often rely on volunteer effort, have been } \\
\text { unable to meet for extended periods in } 2020 \text {. Moreover, the local galleries museums and arts } \\
\text { centres on which they depend have closed, in some cases for good. Considering this dislocation } \\
\text { digital materials generated by community groups in arts and heritage are likely to be at a greater } \\
\text { risk than in } 2019 \text {. }\end{array}$} \\
\hline
\end{tabular}




\begin{tabular}{|c|c|c|}
\hline \multicolumn{2}{|c|}{ Correspondence and Records of Research } & \\
\hline \multicolumn{2}{|c|}{$\begin{array}{l}\text { Correspondence and other records which describe the } \\
\text { configuration and delivery of research but which are } \\
\text { ancillary to the core research outputs, including reviews, } \\
\text { drafts and correspondence between researchers. }\end{array}$} & \\
\hline Group: Research Outputs & Trend in 2020: & Consensus Decision \\
\hline Added to List: 2019 & Trend towards greater risk & Previous category: New Entry \\
\hline $\begin{array}{l}\text { Imminence of Action } \\
\text { Action is recommended } \\
\text { within three years, } \\
\text { assessment in twelve } \\
\text { months. }\end{array}$ & $\begin{array}{l}\text { Significance of Loss } \\
\text { The loss of tools, data or } \\
\text { services within this group } \\
\text { would impact on many } \\
\text { people and sectors. }\end{array}$ & $\begin{array}{l}\text { Effort to Preserve } \\
\text { Loss seems likely: by the time tools } \\
\text { or techniques have been } \\
\text { developed the material will likely } \\
\text { have been lost. }\end{array}$ \\
\hline
\end{tabular}

\section{Examples}

Email boxes of senior academics; social media posts; personal spaces on institutional networks

'Practically Extinct' in the Presence of Aggravating Conditions

Originating researcher no longer active or changed research focus; staff on temporary contracts; dependence on single student or staff member; weak or fluid institutional commitment to subject matter; weak institutional commitment to data sharing; complicated or contested intellectual property; encryption

\section{'Endangered' in the Presence of Good Practice}

Recognition of value of correspondence; integration with CRIS; routine use of EDRMS; documented and managed professionally; separation of personal and corporate identies

\section{Review}

Research data has been an entry in the BitList since 2017 so the Jury this year has tried to spell out the different complexities that arise in the preservation of research outputs more generally. This entry represents archives behind research which is available from previous generations of researchers in physical form but which are now electronic.

\section{Additional Jury Comments}

In ideal circumstance, correspondence should be stored in EDRMS systems separately from research data and subject to different retention schedules i.e. 10-20 years. There may be challenges connecting the EDRMs holdings to the research data and vice versa.

Advocacy and research re the scale of the problem may be required to encourage academics to use EDRMs for example for correspondence and integration with CRIS. Simplified tools and workflows to move data from CRIS to Repository to Preservation systems

2020 Trend: Higher education and research institutions face budget uncertainties and a number of institutions have introduced early severance schemes or put staff on short term contracts at greater risk of redundancy. While this puts other types of research output at risk, the personal nature of correspondence means that the risks are intensified and so this item faces greater risks than identified in 2019. 


\begin{tabular}{|c|c|c|}
\hline \multicolumn{2}{|c|}{$\begin{array}{l}\text { Data Posted to Defunct or Little-used Social } \\
\text { Media Platforms }\end{array}$} & \\
\hline \multicolumn{2}{|c|}{$\begin{array}{l}\text { Older or less widely used social media platforms to which } \\
\text { content has been uploaded but for which no guarantees } \\
\text { have been made about the long term }\end{array}$} & \\
\hline Group: Social Media & Trend & Consensus Decision \\
\hline Added to List: 2017 & No Change & Previous category: Of Concern \\
\hline $\begin{array}{l}\text { Imminence of Action } \\
\text { Action is recommended } \\
\text { within three years, } \\
\text { assessment in twelve } \\
\text { months. }\end{array}$ & $\begin{array}{l}\text { Significance of Loss } \\
\text { The loss of tools, data or } \\
\text { services within this group } \\
\text { would impact on many } \\
\text { people and sectors. }\end{array}$ & $\begin{array}{l}\text { Effort to Preserve } \\
\text { Loss seems likely: by the time tools } \\
\text { or techniques have been } \\
\text { developed the material will likely } \\
\text { have been lost. }\end{array}$ \\
\hline \multicolumn{3}{|l|}{ Examples } \\
\hline \multicolumn{3}{|c|}{$\begin{array}{l}\text { 'Practically Extinct' in the Presence of Aggravating Conditions } \\
\text { Closure of platform; lack of offline equivalent; lack of export functionality; no preservation } \\
\text { undertaking from service provider; unstable business plan from service provider. }\end{array}$} \\
\hline \multicolumn{3}{|c|}{$\begin{array}{l}\text { 'Endangered' in the Presence of Good Practice } \\
\text { Offline Replication; clear notice periods and alerts; committed ongoing maintenance of sen }\end{array}$} \\
\hline \multicolumn{3}{|c|}{$\begin{array}{l}2019 \text { Review } \\
\text { The judges have revived this entry from initial submission in } 2017 \text { that they were not able to } \\
\text { assess at that time. It emphasizes the different threats faced by social media users. Because these } \\
\text { services are older, the need to act is more urgent than for others. }\end{array}$} \\
\hline \multicolumn{3}{|c|}{$\begin{array}{l}\text { Additional Jury Comments } \\
\text { It is to be hoped that some of these have been archived via traditional web archiving and so the } \\
\text { remnants of these sites can be found in bits and pieces in various web archives, but it may be too } \\
\text { late to save some of the content that is likely already be lost. If some of this is still available there } \\
\text { may be hope in trying to preserve but it may be difficult if the platforms aren't willing to share } \\
\text { data or work with preservationists. ArchiveTeam has stepped in here too. There is undoubtedly a } \\
\text { story here which could be used as a call for arms to raise awareness about the preservation of } \\
\text { current social media platforms too }\end{array}$} \\
\hline $\begin{array}{l}\text { Need to decouple the } c \\
\text { content is based on non }\end{array}$ & om the platform. Criticall & $\begin{array}{l}\text { ngered if the availability of the } \\
n \text { ever do is sample some content }\end{array}$ \\
\hline
\end{tabular}




\begin{tabular}{|c|c|c|}
\hline \multicolumn{2}{|c|}{$\begin{array}{l}\text { Digital Archives from Public Enquiries and } \\
\text { Commissions }\end{array}$} & 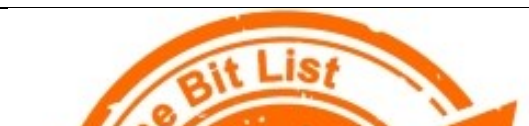 \\
\hline \multicolumn{2}{|c|}{$\begin{array}{l}\text { Data from public enquiries and reconciliation commissions } \\
\text { which can be traumatic, politically uncomfortable and } \\
\text { contested, typically comes in many different forms and } \\
\text { formats. It is not always possible to identify an archival } \\
\text { authority to look after the resulting evidence and } \\
\text { proceedings, and these need carefully managed to ensure } \\
\text { their integrity and accessibility into the future. Data } \\
\text { protection issues and cultural sensitivities only amplify the } \\
\text { challenge to preservations. }\end{array}$} & \\
\hline Group: Digital Legal Records & Trend in 2020: & Consensus Decision \\
\hline Added to List: 2017 & No Change & Previously: Critically Endangered \\
\hline $\begin{array}{l}\text { Imminence of Action } \\
\text { Action is recommended } \\
\text { within twelve months, } \\
\text { detailed assessment is now a } \\
\text { priority }\end{array}$ & $\begin{array}{l}\text { Significance of Loss } \\
\text { The loss of tools, data or } \\
\text { services within this group } \\
\text { would impact on people and } \\
\text { sectors around the world. }\end{array}$ & $\begin{array}{l}\text { Effort to Preserve } \\
\text { It would require a major effort to } \\
\text { prevent losses in this group, such } \\
\text { as the development of new } \\
\text { preservation tools or techniques. }\end{array}$ \\
\hline
\end{tabular}

\section{Examples}

The Tunisian Truth and Dignity Commission to investigate human rights violations committed prior to 2012; enquiries into historical child abuse; Bloody Sunday Enquiry (Saville Inquiry); East Timor Tribunal;

\section{'Practically Extinct' in the Presence of Aggravating Conditions}

risk of falsification; fragile or obsolete media; dependence on proprietary formats or products; lack or loss of documentation; inaccessible to web harvesting technologies; lack of version control; lack of integrity checks or integrity records; poor chain of custody;

\section{'Endangered' in the Presence of Good Practice}

Strong sense of archival responsibility; carefully constructed rules around information privacy that retain robust and appropriate preservation capabilities

\section{Review}

This entry was received in 2017 but has been split into a series of more discrete entries this year. This entry represents a small group of very specific but also highly significant recommendations jury which each have their own challenges but which have sufficient similarities to be taken as a group. The Jury noted that there is in fact considerable evidence of good practice emerging from some of the examples where clear archival responsibility has been the key to progress.

\section{Additional Jury Comments}

The submissions from which this entry is made seem like the tip of an iceberg. Hard to see how to segment it but necessary to raise awareness.

Case files and correspondence are one thing. Retention of these should be clear, but may differ widely between jurisdictions and/or levels of government. If retention is not long term or permanent, risk of loss may not be so critical. Retention of 'unused' or 'potential' evidence is likely a different matter altogether. It may not even been considered a record, and certainly isn't a record of the court. Should it be returned to the suspect or accused? Are their rights being considered here - not just in terms of preservation, but also simply disposition? There are legal and ethical issues around this which need to be fleshed out in conjunction with assessing its preservation risk. 


\begin{tabular}{|c|c|c|}
\hline \multicolumn{2}{|c|}{ Digital Archives of Community Groups } & \\
\hline \multicolumn{2}{|c|}{$\begin{array}{l}\text { Digital materials including ephemera, correspondence and } \\
\text { campaign materials created as a by-product of small scale or } \\
\text { ad-hoc community action groups }\end{array}$} & \\
\hline Group: Community Archives & Trend in 2020: & Consensus Decision \\
\hline Added to List: 2019 & Trend towards greater risk & Previous category: New Entry \\
\hline $\begin{array}{l}\text { Imminence of Action } \\
\text { Action is recommended } \\
\text { within twelve months, } \\
\text { detailed assessment is now a } \\
\text { priority }\end{array}$ & $\begin{array}{l}\text { Significance of Loss } \\
\text { The loss of tools, data or } \\
\text { services within this group } \\
\text { would impact on many } \\
\text { people and sectors. }\end{array}$ & $\begin{array}{l}\text { Effort to Preserve } \\
\text { It would require a major effort to } \\
\text { prevent losses in this group, such } \\
\text { as the development of new } \\
\text { preservation tools or techniques. }\end{array}$ \\
\hline \multicolumn{3}{|c|}{$\begin{array}{l}\text { Archives of smaller and ad-hoc political and campaigning organisations; environmental protests; } \\
\text { sports clubs; smaller religious groups; amateur music or drama; fan groups }\end{array}$} \\
\hline \multicolumn{3}{|c|}{$\begin{array}{l}\text { 'Practically Extinct' in the Presence of Aggravating Conditions } \\
\text { Poor documentation; lack of replication; lack of continuity funding; lack of residual mechanism; } \\
\text { dependence on small number of volunteers, lack of preservation mandate; lack of preservation } \\
\text { thinking at the outset; conflation of backup with preservation; conflation of access and } \\
\text { preservation; inaccessible to web archiving; dependence on social media providers; distrust of } \\
\text { 'official' agencies. }\end{array}$} \\
\hline \multicolumn{3}{|c|}{$\begin{array}{l}\text { 'Endangered' in the Presence of Good Practice } \\
\text { Residual archive with residual funding able to receive and support collections; active user } \\
\text { community; intellectual property managed to enable preservation. }\end{array}$} \\
\hline \multicolumn{3}{|c|}{$\begin{array}{l}\text { The jury created this entry in } 2019 \text { as a subset of 'Community Archives and Community-Generated } \\
\text { Content' which has been split into two to provide greater specificity in recommendations. }\end{array}$} \\
\hline \multicolumn{3}{|c|}{$\begin{array}{l}\text { Typically born digital material is more at risk - community groups simple don't know about the risk } \\
\text { of loss. Many are unaware of digital preservation terminology. It is the ad-hoc nature of these } \\
\text { groups and projects which is of great concern. }\end{array}$} \\
\hline \multicolumn{3}{|c|}{$\begin{array}{l}\text { Significant need to raise awareness and provide a "home" but also to do so with sufficient } \\
\text { sensitivity so as to ensure community groups remain in control of their own material. }\end{array}$} \\
\hline \multicolumn{3}{|c|}{$\begin{array}{l}2020 \text { Trend: community groups such as sports clubs, religious communities, arts and political } \\
\text { groups, often rely on volunteer effort, have been unable to meet for extended periods in } 2020 . \\
\text { Moreover the local community centres, clubs or places of worship on which they depend have } \\
\text { closed, in some cases for good. Consequently this group faces greater risks than in } 2019 \text {. }\end{array}$} \\
\hline
\end{tabular}




\begin{tabular}{|c|c|c|}
\hline \multicolumn{2}{|c|}{ Digital Archives of music production } & \\
\hline \multicolumn{2}{|c|}{$\begin{array}{l}\text { Digital materials created by musicians and fans as a by- } \\
\text { product of performance or recording, not otherwise } \\
\text { published or shared }\end{array}$} & \\
\hline Group: Sound and Vision & Trend in 2020: & Consensus Decision \\
\hline Added to List: 2019 & No Change & Previous category: New Entry \\
\hline $\begin{array}{l}\text { Imminence of Action } \\
\text { Action is recommended } \\
\text { within three years, } \\
\text { assessment within } 12 \\
\text { months }\end{array}$ & $\begin{array}{l}\text { Significance of Loss } \\
\text { The loss of tools, data or } \\
\text { services within this group } \\
\text { would impact on people and } \\
\text { sectors around the world. }\end{array}$ & $\begin{array}{l}\text { Effort to Preserve } \\
\text { It would require a major effort to } \\
\text { prevent losses in this group, such } \\
\text { as the development of new } \\
\text { preservation tools or techniques. }\end{array}$ \\
\hline \multicolumn{3}{|c|}{$\begin{array}{l}\text { Examples } \\
\text { Pre-production notes; demo recordings; photography; correspondence. }\end{array}$} \\
\hline \multicolumn{3}{|c|}{$\begin{array}{l}\text { ‘Practically Extinct' in the Presence of Aggravating Conditions } \\
\text { fragile or obsolete media for offline content; service provider preservation capability for online } \\
\text { content; dependence on proprietary formats or products; lack or loss of documentation; } \\
\text { uncertainty over intellectual property rights; lack of version control; lack of policy or mandate }\end{array}$} \\
\hline \multicolumn{3}{|c|}{$\begin{array}{l}\text { 'Endangered' in the Presence of Good Practice } \\
\text { Replication; clarity of intellectual property rights; preservation agency involved and capable of } \\
\text { looking after content }\end{array}$} \\
\hline \multicolumn{3}{|c|}{$\begin{array}{l}2019 \text { Review } \\
\text { This entry has been split out of the previous entry for 'Digital Music Production and Sharing' } \\
\text { though it has overlaps with other entries including 'Pre-production TV and Movie materials'. A } \\
\text { separate entry has been included to emphasise the inherent and value of the archival materials } \\
\text { relating to the recording process over and above the recordings themselves. }\end{array}$} \\
\hline \multicolumn{3}{|c|}{$\begin{array}{l}\text { Additional Jury Comments } \\
\text { Inevitable loss of existing data but it would require major effort to fix in terms of identifying } \\
\text { organizations who are preserving this content. Not clear that this is being done already }\end{array}$} \\
\hline
\end{tabular}




\begin{tabular}{|c|c|c|}
\hline \multicolumn{2}{|c|}{$\begin{array}{l}\text { Digital Evidence and Records of Investigation } \\
\text { Prior to Court }\end{array}$} & \\
\hline \multicolumn{2}{|c|}{$\begin{array}{l}\text { Digital materials assessed by police and other authorities in } \\
\text { the course of investigation and retained as evidence of due } \\
\text { process such as case files and correspondence, including } \\
\text { materials not submitted to court }\end{array}$} & \\
\hline Group: Digit & Tre & nsensus Decision \\
\hline Added to List: 2019 & & evious category: New Entry \\
\hline $\begin{array}{l}\text { Action is recommended } \\
\text { within three years, detailed } \\
\text { assessment within } 12 \\
\text { months }\end{array}$ & $\begin{array}{l}\text { Significance of Loss } \\
\text { The loss of tools, data or } \\
\text { services within this group } \\
\text { would impact on people and } \\
\text { sectors around the world. }\end{array}$ & $\begin{array}{l}\text { Effort to Preserve } \\
\text { It would require a major effort to } \\
\text { prevent losses in this group, such } \\
\text { as the development of new } \\
\text { preservation tools or techniques. }\end{array}$ \\
\hline \multicolumn{3}{|c|}{$\begin{array}{l}\text { Examples } \\
\text { CCTV; Email; 3d scanning; social media interactions; police records; court records; text messages. }\end{array}$} \\
\hline \multicolumn{3}{|c|}{$\begin{array}{l}\text { 'Practically Extinct' in the Presence of Aggravating Conditions } \\
\text { Poor chain of custody; fragile or obsolete media; dependence on proprietary formats or products; } \\
\text { lack or loss of documentation; inaccessible to web harvesting technologies; lack of version } \\
\text { control; lack of integrity checks or integrity records; poor chain of custody. }\end{array}$} \\
\hline \multicolumn{3}{|c|}{$\begin{array}{l}\text { 'Endangered' in the Presence of Good Practice } \\
\text { Meticulous transfer and disclosure processes }\end{array}$} \\
\hline \multicolumn{3}{|c|}{$\begin{array}{l}2019 \text { Review } \\
\text { This entry is a subset of an entry made in } 2017 \text { for 'Digital Legal Records and Evidence' which the } \\
\text { Jury has decided to split into four more discrete entries this year. This category includes evidence } \\
\text { prior to court that may form part of an investigation or gathering of evidence but which are not } \\
\text { formally submitted as evidence. It recognizes that police and other investigating authorities are } \\
\text { not limited in the types of evidence that they need to administer, but that this creates an almost } \\
\text { unbounded limit of preservation requirements to ensure authenticity and admissibility. }\end{array}$} \\
\hline \multicolumn{3}{|c|}{$\begin{array}{l}\text { Additional Jury Comments } \\
\text { Case files and correspondence are one thing: retention of these should be clear but may differ } \\
\text { widely between jurisdictions and/or levels of government. If retention is not long term or } \\
\text { permanent, risk of loss may not be so critical. Retention of 'unused' or 'potential' evidence is likely } \\
\text { a different matter altogether. is it even a record? certainly it isn't a record of the court. Should it } \\
\text { be returned to the suspect or accused? Are their rights being considered here - not just in terms } \\
\text { of preservation, but also simply disposition? There may be legal and ethical issues around this } \\
\text { which need to be fleshed out in conjunction with assessing its preservation risk. }\end{array}$} \\
\hline
\end{tabular}




\begin{tabular}{|c|c|c|}
\hline \multicolumn{2}{|c|}{ Family or Personal Records } & \\
\hline \multicolumn{2}{|c|}{$\begin{array}{l}\text { Digital content and communications generated for persona } \\
\text { consumption in a domestic setting and which may be of } \\
\text { limited general interest but highly valuable to family } \\
\text { members and genealogy. }\end{array}$} & \\
\hline Group: Personal Archives & Trend in 2020: & Consensus Decision \\
\hline Added to List: 2017 & No Change & Previously: Critically Endangered \\
\hline $\begin{array}{l}\text { Imminence of Action } \\
\text { Action is recommended } \\
\text { within three years, detailed } \\
\text { assessment within } 12 \\
\text { months }\end{array}$ & $\begin{array}{l}\text { Significance of Loss } \\
\text { The loss of data, tools or } \\
\text { services within this group } \\
\text { would have a localised } \\
\text { impact. }\end{array}$ & $\begin{array}{l}\text { Effort to Preserve } \\
\text { Loss seems likely: by the time tools } \\
\text { or techniques have been } \\
\text { developed the material will likely } \\
\text { have been lost. }\end{array}$ \\
\hline
\end{tabular}

\section{Examples}

childhood photographs and videos; School or graduation photos; wedding photos and movies; electronic correspondence (email, messenger, WhatsApp)

\section{'Practically Extinct' in the Presence of Aggravating Conditions}

storage on portable media or poor storage; dependence on devices or processes; dependence on obsolete or proprietary formats; storage media out of warranty; single copies; inappropriate dependence on service provider; inappropriate encryption or password protection; lack of awareness or planning; loss or lack of documentation; over-abundance; inability to act in a timely manner; confusion over intellectual property

\section{'Endangered' in the Presence of Good Practice}

Replication; action in a timely manner; open formats; selection and appraisal; archival agency 2019 Review

This was introduced to the BitList in 2017. Although research and advice on preservation of personal records have been available for some time, outreach and training has not reached the audience and there has been no material improvement in the risks faced by this category since 2017. It is reasonable to assume that the number of digital objects in this category has increased thus the consequences of loss have expanded.

It is also a very large category and may be usefully broken into a series of components to represent the complexity more effectively and present a more nuanced action plan.

\section{Additional Jury Comments}

A strong overlap with community archives, except noting that responsibility is even more localised. Some loss is inevitable.

This matter needs awareness raising. Education is needed, such as digital preservation as a survival skill for teenagers. Also simple and cheap tools or pathways to preservation are needed. 


\begin{tabular}{|c|c|c|}
\hline \multicolumn{2}{|l|}{ Grey literature } & \\
\hline \multicolumn{2}{|c|}{$\begin{array}{l}\text { Semi-published research outputs such as blogs, } \\
\text { dissertations, informal conference papers or commissioned } \\
\text { reports which are not formally published but which can } \\
\text { contain original and insightful contributions within scholarly } \\
\text { communications }\end{array}$} & \\
\hline Group & Trend & onsensus Decision \\
\hline Added to List: 2019 & Trend towards greater risk & Previous category: New Entry \\
\hline $\begin{array}{l}\text { Imminence of Action } \\
\text { Action is recommended } \\
\text { within three years, detailed } \\
\text { assessment within twelve } \\
\text { months }\end{array}$ & $\begin{array}{l}\text { Significance of Loss } \\
\text { The loss of tools, data or } \\
\text { services within this group } \\
\text { would impact on people and } \\
\text { sectors around the world. }\end{array}$ & $\begin{array}{l}\text { Effort to Preserve } \\
\text { It would require a major effort to } \\
\text { prevent losses in this group, such } \\
\text { as the development of new } \\
\text { preservation tools or techniques. }\end{array}$ \\
\hline \multicolumn{3}{|c|}{$\begin{array}{l}\text { Examples } \\
\text { Blogs, technical reports, conference papers, dissertations, commercial research }\end{array}$} \\
\hline \multicolumn{3}{|c|}{$\begin{array}{l}\text { 'Practically Extinct' in the Presence of Aggravating Conditions } \\
\text { Originating researcher no longer active or changed research focus; staff on temporary contracts; } \\
\text { dependence on single student or staff member; weak or fluid institutional commitment to subject } \\
\text { matter; weak institutional commitment to data sharing; complicated or contested intellectual } \\
\text { property; encryption; Lack of recognition; non-disclosure agreements; }\end{array}$} \\
\hline \multicolumn{3}{|c|}{$\begin{array}{l}\text { 'Endangered' in the Presence of Good Practice } \\
\text { Use of persistent identifiers; embedded within repository infrastructure; quality assurance }\end{array}$} \\
\hline \multicolumn{3}{|c|}{$\begin{array}{l}2019 \text { Review } \\
\text { Research data has been an entry in the BitList since } 2017 \text { so the Jury this year has tried to spell out } \\
\text { the different complexities that arise in the preservation of research outputs more generally. This } \\
\text { entry represents activities which build towards formal publications and research outputs but } \\
\text { which do not typically accumulate in institutional repositories. }\end{array}$} \\
\hline \multicolumn{3}{|c|}{$\begin{array}{l}\text { Additional Jury Comments } \\
\text { Loss of material like this would be common in the analogue world, but in the digital age we have } \\
\text { the capacity and perhaps something of a responsibility to ensure that it is captured: more of an } \\
\text { opportunity lost to extend the available research resource. The ADS's Grey Literature Library } \\
\text { demonstrates what could be done if information architectures are deployed to mirror and extend } \\
\text { professional practice. }\end{array}$} \\
\hline \multicolumn{3}{|c|}{$\begin{array}{l}\text { Workflows and policies re tagging, collecting and EDRMS may help protect such data into the } \\
\text { future. Past materials are almost certainly partially lost }\end{array}$} \\
\hline \multicolumn{3}{|c|}{$\begin{array}{l}\text { Trend in 2020: Higher education and research institutions face budget uncertainties and a number } \\
\text { of institutions have introduced early severance schemes or put staff on short term contracts at } \\
\text { greater risk of redundancy. While this puts other types of research output at risk, the ad hoc } \\
\text { nature of grey literature means that this entry is at greater risk. }\end{array}$} \\
\hline
\end{tabular}




\begin{tabular}{|c|c|c|}
\hline \multicolumn{2}{|c|}{ Legacy research web collections } & \\
\hline \multicolumn{2}{|c|}{$\begin{array}{l}\text { Since 1994, people have set up collections of digital content } \\
\text { on the web with software now outdated. Those collections } \\
\text { are valuable, but lose funding and care as institutions re- } \\
\text { configure their tasks and individuals retreat from their task } \\
\text { due to retirement or (as volunteers) to old age. }\end{array}$} & \\
\hline Group: Web & Trend in 2020: & Consensus Decision \\
\hline Added to List: 2019 & No $C$ & Previous category: New Entry \\
\hline $\begin{array}{l}\text { Imminence of Action } \\
\text { Action is recommended } \\
\text { within three years, detailed } \\
\text { assessment in } 12 \text { months }\end{array}$ & $\begin{array}{l}\text { Significance of Loss } \\
\text { The loss of tools, data or } \\
\text { services within this group } \\
\text { would impact on people and } \\
\text { sectors around the world. }\end{array}$ & $\begin{array}{l}\text { Effort to Preserve } \\
\text { It would require a major effort to } \\
\text { prevent losses in this group, such } \\
\text { as the development of new } \\
\text { preservation tools or techniques. }\end{array}$ \\
\hline \multicolumn{3}{|c|}{$\begin{array}{l}\text { Examples } \\
\text { Academic and institutional website from the first decade of the web containing details of research } \\
\text { projects and interests as well as research data. }\end{array}$} \\
\hline \multicolumn{3}{|c|}{$\begin{array}{l}\text { 'Practically Extinct' in the Presence of Aggravating Conditions } \\
\text { Inaccessible to web archive; bespoke code; insufficient documentation; uncertain intellectual } \\
\text { property right. }\end{array}$} \\
\hline \multicolumn{3}{|c|}{ 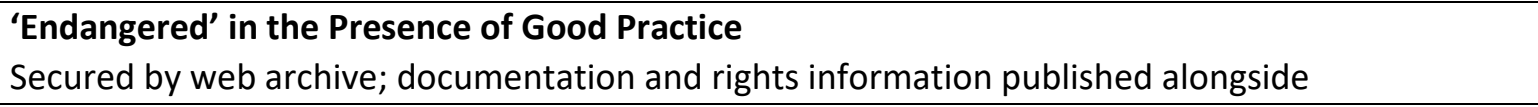 } \\
\hline \multicolumn{3}{|c|}{$\begin{array}{l}2019 \text { Review } \\
\text { This is a new entry received from the open submission process and assessed by the Jury. It has an } \\
\text { overlap with the entry with 'Semi-Published Research' Data' which was classified as 'Endangered'. } \\
\text { The Jury has approved this entry as a means of distinguishing 'current' and 'legacy' collections: } \\
\text { and in this case the fact that materials are no longer actively maintained means that the risks of } \\
\text { loss are greater. }\end{array}$} \\
\hline \multicolumn{3}{|c|}{$\begin{array}{l}\text { Additional Jury Comments } \\
\text { The Internet Archive and other national web archiving bodies have copies of a lot of websites } \\
\text { which would fit into this category, but by no means all. There's also a distinction between the } \\
\text { software or code used to deliver the user experience and the data. Such code is secondary to the } \\
\text { content. }\end{array}$} \\
\hline
\end{tabular}




\begin{tabular}{|c|c|c|}
\hline \multicolumn{2}{|c|}{ Maritime Archaeological Archives } & \\
\hline \multicolumn{2}{|c|}{$\begin{array}{l}\text { These are collection of digital records from maritime } \\
\text { archaeological work including photographs, maps and plans, } \\
\text { field notebooks, post-excavation finds analysis and other } \\
\text { analytical records. }\end{array}$} & \\
\hline Group: Museum Data & Trend ir & Consensus Decision \\
\hline Added to List: New Entry & No Change & Previous category: New Entry \\
\hline $\begin{array}{l}\text { Imminence of Action } \\
\text { Action is recommended } \\
\text { within } 12 \text { months, detailed } \\
\text { assessment is now a priority }\end{array}$ & $\begin{array}{l}\text { Significance of Loss } \\
\text { The loss of tools, data or } \\
\text { services within this group } \\
\text { would impact on people and } \\
\text { sectors around the world. }\end{array}$ & $\begin{array}{l}\text { Effort to Preserve } \\
\text { It would require a major effort to } \\
\text { prevent losses in this group, such } \\
\text { as the development of new } \\
\text { preservation tools or techniques. }\end{array}$ \\
\hline \multicolumn{3}{|c|}{$\begin{array}{l}\text { Examples } \\
\text { Records of excavations in marine environments which may fall outside the jurisdiction of } \\
\text { terrestrial heritage services. }\end{array}$} \\
\hline \multicolumn{3}{|c|}{$\begin{array}{l}\text { 'Practically Extinct' in the Presence of Aggravating Conditions } \\
\text { Poor documentation; lack of preservation mandate; dependence on proprietary and non-standard } \\
\text { data types }\end{array}$} \\
\hline \multicolumn{3}{|c|}{$\begin{array}{l}\text { 'Endangered' in the Presence of Good Practice } \\
\text { Preservation planning from the outset; subject specialist repository; user community }\end{array}$} \\
\hline \multicolumn{3}{|c|}{$\begin{array}{l}2019 \text { Review } \\
\text { This is a new entry taken from the open submission process in 2019. It is grouped with Museum } \\
\text { data sets as archaeological archives typically make their way to museums, but it is also closely } \\
\text { aligned to research data. }\end{array}$} \\
\hline \multicolumn{3}{|c|}{$\begin{array}{l}\text { Additional Jury Comments } \\
\text { There are trusted custodians of this data such as ADS, DANS or the British Museum as well as in } \\
\text { oceanographic research agencies, but perhaps hard to integrate good practice at an international } \\
\text { scale. The real challenge therefore is in identifying and sustaining a custodian as other bodies } \\
\text { have experience with this data. The proliferation of innovative data recording technologies also } \\
\text { implies likely problems of format dependence and documentation. }\end{array}$} \\
\hline
\end{tabular}




\begin{tabular}{|c|c|c|}
\hline \multicolumn{2}{|c|}{$\begin{array}{l}\text { Media Art by deceased artists or defunct } \\
\text { workshops }\end{array}$} & \\
\hline \multicolumn{2}{|c|}{$\begin{array}{l}\text { Media art where the artists or creative technicians are } \\
\text { either deceased or not able to provide guidance on } \\
\text { authenticity and installation }\end{array}$} & \\
\hline Group: Media Art & Trend in 2020: & Consensus Decision \\
\hline Added to List: 2019 & Trend towards greater risk & Previous category: New Entry \\
\hline $\begin{array}{l}\text { Imminence of Action } \\
\text { Action is recommended } \\
\text { within twelve months, } \\
\text { detailed assessment is now a } \\
\text { priority }\end{array}$ & $\begin{array}{l}\text { Significance of Loss } \\
\text { The loss of tools, data or } \\
\text { services within this group } \\
\text { would impact on people and } \\
\text { sectors around the world. }\end{array}$ & $\begin{array}{l}\text { Effort to Preserve } \\
\text { Loss seems likely: by the time tools } \\
\text { or techniques have been } \\
\text { developed the material will likely } \\
\text { have been lost. }\end{array}$ \\
\hline
\end{tabular}

\section{Examples}

Works produced by media artists now deceased, such as: Jeremy Blake, Beatriz Da Costa, Heiko Daxl or Stanislaus Ostoja-Kotkowski.

\section{'Practically Extinct' in the Presence of Aggravating Conditions}

Lack of documentation to enable maintenance; lack of clarity with respect to intellectual property; complex interdependencies on specific hardware, software or operating systems; lack of capacity in the gallery or workshop; lack of strategic investment; complex external dependencies; loss of institutional memory resulting from staff churn; poor working relationship between the gallery and artist/workshop; lack of conservation assessment.

\section{'Endangered' in the Presence of Good Practice}

Strong documentation; clarity of preservation path and ensuing responsibilities; proven preservation plan; capacity of workshop to support re-installation; capacity of gallery to conserve; capacity of gallery to re-install; retention of institutional memory including archives of correspondence between gallery and artist/workshop; strong and continuing working relationship between the gallery and artist/workshop; regular conservation assessment.

\section{Review}

Media Art was introduced in 2017, though with particular reference to historical media art which was categorised as 'critically endangered'. The jury has split this to ensure greater specificity in its recommendation. This entry represents works held in galleries where the artist is deceased or the workshop has closed and there is limited prospect to obtain new documentation.

\section{Additional Jury Comments}

This entry includes a point in the lifecycle of all media art so good practice recommendations are likely to become more important over time. Preservation issues may not become visible until the piece is brought out of storage for loan or exhibition, underscoring the value of continuous or periodic conservation assessment. The range of data/formats/hardware/software etc. can be new and varied providing organisations with an ongoing technical challenge which they are not initially equipped to deal with. Some loss seems inevitable.

2020 Trend: Galleries, which often rely on visitors for income, have been closed for extended periods. In these circumstances of economic dislocation, media art collections in galleries are likely to be at a greater risk than in 2019. 


\begin{tabular}{|c|c|c|}
\hline \multicolumn{2}{|c|}{ Media Inside Paper Files } & \\
\hline \multicolumn{2}{|c|}{$\begin{array}{l}\text { Media inside paper files occur in records since the } 1980 \text { s } \\
\text { and will continue to do so for many years. }\end{array}$} & \\
\hline Group: Portable Media & Trend in & Consensus Decision \\
\hline Added to List:2019 & No Change & Previously: New Entry \\
\hline $\begin{array}{l}\text { Imminence of Action } \\
\text { Action is recommended } \\
\text { within three years, } \\
\text { assessment within } 12 \\
\text { months }\end{array}$ & $\begin{array}{l}\text { Significance of Loss } \\
\text { The loss of tools, data or } \\
\text { services within this group } \\
\text { would impact on many } \\
\text { people and sectors. }\end{array}$ & $\begin{array}{l}\text { Effort to Preserve } \\
\text { It would require a small effort to } \\
\text { prevent losses in this group, such } \\
\text { as the deployment of proven } \\
\text { preservation tools or techniques. }\end{array}$ \\
\hline \multicolumn{3}{|c|}{$\begin{array}{l}\text { Examples } \\
\text { Digital media mixed with paper files in records offices and filing cabinets of almost every kind of } \\
\text { enterprise. }\end{array}$} \\
\hline \multicolumn{3}{|c|}{$\begin{array}{l}\text { 'Practically Extinct' in the Presence of Aggravating Conditions } \\
\text { Unsustainable effort to assess; exotic or obsolete media; poor storage; lack of descriptive } \\
\text { labelling; }\end{array}$} \\
\hline \multicolumn{3}{|c|}{$\begin{array}{l}\text { 'Endangered' in the Presence of Good Practice } \\
\text { Carefully labelled; managed programme of assessment and retrieval; robust media used }\end{array}$} \\
\hline \multicolumn{3}{|c|}{$\begin{array}{l}2019 \text { Review } \\
\text { This is a new entry submitted through the open submission and validated by the Jury who report } \\
\text { the significant amounts of digital media being transferred to archives fold into traditional files. } \\
\text { The Jury noted that it is relatively simple to preserve this material once identified using standard } \\
\text { tools, but it can be an 'unknown unknown' and that assessment can seem overwhelming. }\end{array}$} \\
\hline \multicolumn{3}{|c|}{$\begin{array}{l}\text { Additional Jury Comments } \\
\text { Highly dependent on who is looking after the portable formats. There are good example, for } \\
\text { example in libraries, where disks are stored at the back of books or front of magazines and can be } \\
\text { processed at the point of acquisition. In archives, however dealing with bit-level preservation of } \\
\text { external media (often on legacy formats) is largely an unquantified problem and so resource } \\
\text { commitments will not be in place. So there is a method and tools but simply no time committed } \\
\text { and no proper assessment either. In other agencies the issue will not have even have been } \\
\text { considered and for them it will be much harder over time, with some inevitable loss. }\end{array}$} \\
\hline
\end{tabular}




\begin{tabular}{|c|c|c|}
\hline \multicolumn{2}{|c|}{ Non-current Hard Disk Technologies } & \\
\hline \multicolumn{2}{|c|}{$\begin{array}{l}\text { Materials saved to storage devices with a variety of } \\
\text { underlying magnetic or solid-state technologies that are } \\
\text { hardwired into a computer that is no longer under warranty } \\
\text { or supported: typically hard disks more than five years old. }\end{array}$} & \\
\hline Group: Integrated Storage & Trend in 2020: & Consensus Decision \\
\hline Added to List: 2019 & No Change & Previous category: New Entry \\
\hline $\begin{array}{l}\text { Imminence of Action } \\
\text { Action is recommended } \\
\text { within twelve months, } \\
\text { detailed assessment is now a } \\
\text { priority }\end{array}$ & $\begin{array}{l}\text { Significance of Loss } \\
\text { The loss of tools, data or } \\
\text { services within this group } \\
\text { would impact on people and } \\
\text { sectors around the world. }\end{array}$ & $\begin{array}{l}\text { Effort to Preserve } \\
\text { It would require a small effort to } \\
\text { prevent losses in this group, such } \\
\text { as the deployment of proven } \\
\text { preservation tools or techniques }\end{array}$ \\
\hline \multicolumn{3}{|l|}{$\begin{array}{l}\text { Examples } \\
\text { Disks installed into computers }\end{array}$} \\
\hline \multicolumn{3}{|c|}{$\begin{array}{l}\text { 'Practically Extinct' in the Presence of Aggravating Conditions } \\
\text { Lack of replication; poor storage; non-standard connections or controllers; aggressive } \\
\text { compression; encryption }\end{array}$} \\
\hline \multicolumn{3}{|c|}{$\begin{array}{l}\text { Maintenance schedule; renewable extendable warranty; best practice storage and operation; } \\
\text { replication }\end{array}$} \\
\hline \multicolumn{3}{|c|}{$\begin{array}{l}\text { The judges have introduced this entry to ensure that the range of media storage is properly } \\
\text { assessed and presented. The lifecycles of most consumer hard disk technology is stable in } \\
\text { comparison to portable devices because they are integrated into systems and therefore inherit } \\
\text { the lifecycle and replacement of the entire system. This is less true at scale however where disks } \\
\text { are used in storage arrays and refreshment is more loosely tied to the server architecture. } \\
\text { Storage at scale also means the percentage likelihood of finding a disk failure increases. }\end{array}$} \\
\hline \multicolumn{3}{|c|}{$\begin{array}{l}\text { Perversely the greater density of newer disks, as well as encryption and compression mean that } \\
\text { they can be more fragile than older disks with less density and less sophisticated read/write } \\
\text { technologies. The age of a disk is not the best or only indicator of its reliability. }\end{array}$} \\
\hline
\end{tabular}




\begin{tabular}{|c|c|c|}
\hline \multicolumn{2}{|c|}{ Non-current Portable Magnetic Media } & \\
\hline \multicolumn{2}{|c|}{$\begin{array}{l}\text { Materials saved to floppy disks, tape, portable hard disks or } \\
\text { other magnetic storage devices where the media is out of } \\
\text { warranty and reader devices may no longer be supported or } \\
\text { integrated easily into hardware infrastructure: typically } \\
\text { more than five years old. }\end{array}$} & \\
\hline Group: Portable Media & Trend ir & Consensus Decision \\
\hline Added to List: 2019 & No Change & Previous category: New Entry \\
\hline $\begin{array}{l}\text { Imminence of Action } \\
\text { Action is recommended } \\
\text { within three years, detailed } \\
\text { assessment is in } 12 \text { months }\end{array}$ & $\begin{array}{l}\text { Significance of Loss } \\
\text { The loss of tools, data or } \\
\text { services within this group } \\
\text { would impact on many } \\
\text { people and sectors. }\end{array}$ & $\begin{array}{l}\text { Effort to Preserve } \\
\text { It would require a major effort to } \\
\text { prevent losses in this group, } \\
\text { including the development of new } \\
\text { preservation tools or techniques }\end{array}$ \\
\hline \multicolumn{3}{|c|}{$\begin{array}{l}\text { Examples } \\
\text { Floppy disks; tape; certain kinds of portable hard disks, zipdrives. }\end{array}$} \\
\hline \multicolumn{3}{|c|}{$\begin{array}{l}\text { 'Practically Extinct' in the Presence of Aggravating Conditions } \\
\text { Poor storage; inability to access readers; no replication; encryptio }\end{array}$} \\
\hline \multicolumn{3}{|c|}{$\begin{array}{l}\text { Active management; dependable access to readers; strong documentation; documentation } \\
\text { independent from the media }\end{array}$} \\
\hline \multicolumn{3}{|c|}{$\begin{array}{l}2019 \text { Review } \\
\text { The judges have introduced this entry to ensure that the range of media storage is properly } \\
\text { assessed and presented. Portable magnetic media was ubiquitous but is fragile not just to } \\
\text { physical wear and tear but also to magnetic interference and bit-rot. The substrates of the disks } \\
\text { can prove unstable and in some cases proprietary reader technology means that the disk becomes } \\
\text { obsolete before it degrades. Storage at scale also means the percentage likelihood of failure } \\
\text { increases }\end{array}$} \\
\hline \multicolumn{3}{|c|}{$\begin{array}{l}\text { Additional Jury Comments } \\
\text { There is really no excuse for using floppy disks for storage these days. Tape is a different } \\
\text { proposition since it allows high-density back up offline and nearline. But there are challenges with } \\
\text { backwards compatibility of popular and even relatively recent LTO versions. }\end{array}$} \\
\hline
\end{tabular}




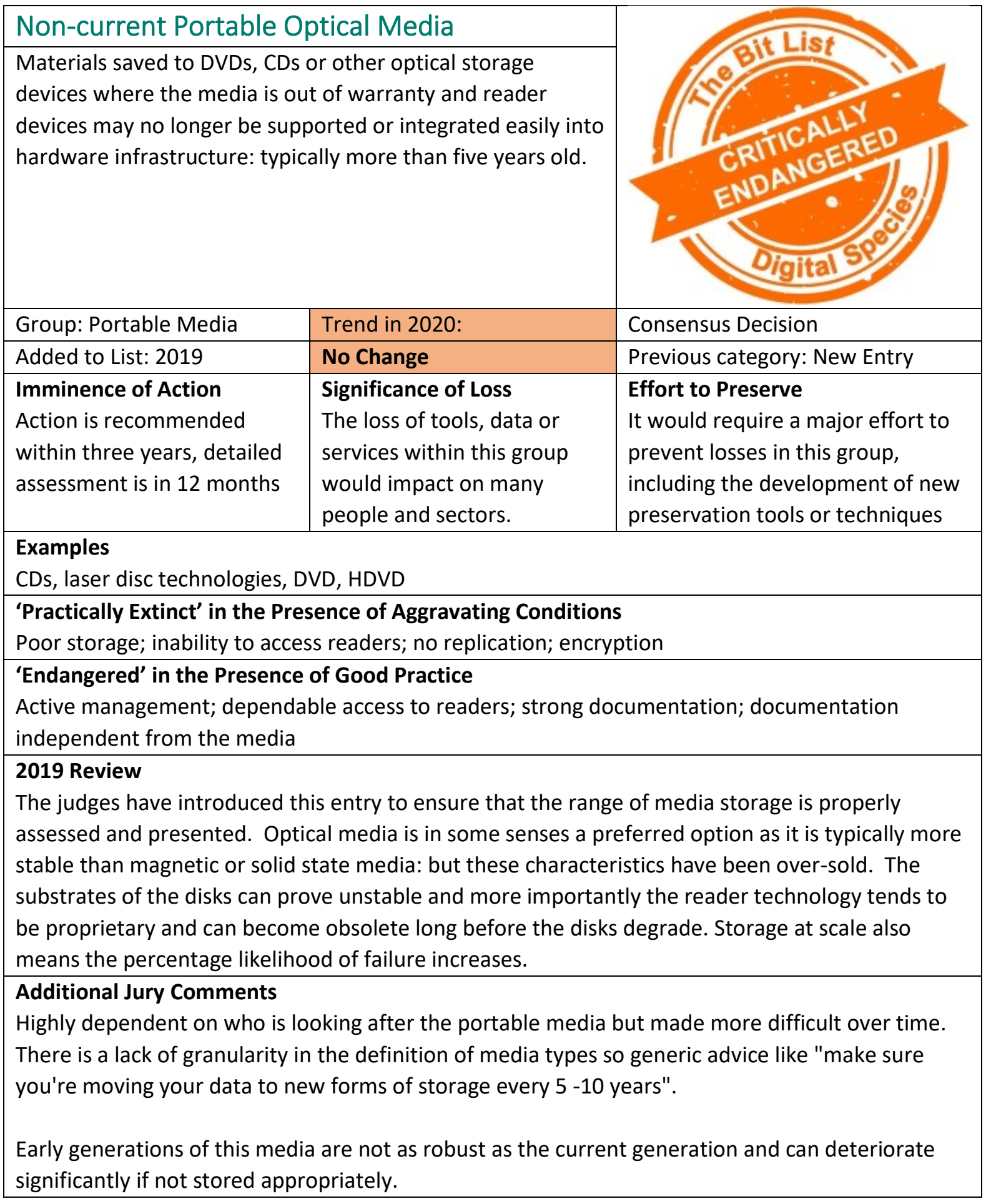




\begin{tabular}{|c|c|c|}
\hline \multicolumn{2}{|c|}{ Non-current Portable Solid-State Media } & \\
\hline \multicolumn{2}{|c|}{$\begin{array}{l}\text { Materials saved to flash or other solid-state storage devices } \\
\text { where the media is out of warranty and reader devices may } \\
\text { no longer be supported or integrated easily into hardware } \\
\text { infrastructure: typically more than five years old. }\end{array}$} & \\
\hline Group: Portable Media & Trend in 2020: & Consensus Decision \\
\hline Added to List: 2019 & No Change & Previous category: New Entry \\
\hline $\begin{array}{l}\text { Imminence of Action } \\
\text { Action is recommended } \\
\text { within three years, detailed } \\
\text { assessment is in } 12 \text { months }\end{array}$ & $\begin{array}{l}\text { Significance of Loss } \\
\text { The loss of tools, data or } \\
\text { services within this group } \\
\text { would impact on many } \\
\text { people and sectors. }\end{array}$ & $\begin{array}{l}\text { Effort to Preserve } \\
\text { It would require a major effort to } \\
\text { prevent losses in this group, } \\
\text { including the development of new } \\
\text { preservation tools or techniques }\end{array}$ \\
\hline \multicolumn{3}{|c|}{$\begin{array}{l}\text { Examples } \\
\text { USB sticks and pen drives; Flash storage in cameras and phones; certain types of portable hard } \\
\text { disk }\end{array}$} \\
\hline \multicolumn{3}{|c|}{$\begin{array}{l}\text { 'Practically Extinct' in the Presence of Aggravating Conditions } \\
\text { Poor physical storage; inability to access readers; no replication; encryption }\end{array}$} \\
\hline \multicolumn{3}{|c|}{$\begin{array}{l}\text { 'Endangered' in the Presence of Good Practice } \\
\text { Active management; dependable access to readers; strong documentation; documentation } \\
\text { independent from the media }\end{array}$} \\
\hline \multicolumn{3}{|c|}{$\begin{array}{l}2019 \text { Review } \\
\text { The judges have introduced this entry to ensure that the range of media storage is properly } \\
\text { assessed and presented. Solid state media - typically flash - provides very fast access to data but } \\
\text { can fail without warning. This is because it is typically subject to a limited number of } \\
\text { program/erase cycles, as well as 'read/disturb' effects. Storage at scale also means the percentage } \\
\text { likelihood of failure increases. }\end{array}$} \\
\hline \multicolumn{3}{|c|}{$\begin{array}{l}\text { Additional Jury Comments } \\
\text { Early generations of media and cheap giveaways are not robust and can deteriorate significantly } \\
\text { over time. }\end{array}$} \\
\hline
\end{tabular}




\begin{tabular}{|c|c|c|}
\hline \multicolumn{2}{|l|}{ Offline Gaming } & \\
\hline \multicolumn{2}{|c|}{$\begin{array}{l}\text { Interactions and experiences of games and related } \\
\text { interactive virtual worlds, representing a significant } \\
\text { investment of skill and time by players, and significant } \\
\text { elements of cultural output in the late 20th and early 21st } \\
\text { century. }\end{array}$} & \\
\hline Group: & & onsensus Decision \\
\hline Adde & & Previously: Critically Endangered \\
\hline $\begin{array}{l}\text { Imminence of Action } \\
\text { Action is recommended } \\
\text { within twelve months, } \\
\text { detailed assessment is now a } \\
\text { priority }\end{array}$ & $\begin{array}{l}\text { Significance of Loss } \\
\text { The loss of tools, data or } \\
\text { services within this group } \\
\text { would impact on people and } \\
\text { sectors around the world. }\end{array}$ & $\begin{array}{l}\text { Effort to Preserve } \\
\text { Loss seems likely: by the time tools } \\
\text { or techniques have been } \\
\text { developed the material will likely } \\
\text { have been lost. }\end{array}$ \\
\hline \multicolumn{3}{|c|}{$\begin{array}{l}\text { Examples } \\
\text { Single player games, especially those which feature significant player } \\
\text { player choice, including Role-Playing Games (RPGS) such as The Elder } \\
\text { that rely on unique peripherals to play, including rhythm action titles }\end{array}$} \\
\hline \multicolumn{3}{|c|}{$\begin{array}{l}\text { 'Practically Extinct' in the Presence of Aggravating Conditions } \\
\text { Complex hardware dependencies or bespoke hardware; dependence on obsolete, low usage } \\
\text { operating systems; no emulation pathway; complex IPR; older magnetic media; free distribution } \\
\text { on magazines; loss of underlying code or gaming engine; limited or no commercial interest. }\end{array}$} \\
\hline \multicolumn{3}{|c|}{$\begin{array}{l}\text { 'Endangered' in the Presence of Good Practice } \\
\text { emulation pathway; source code; trusted repository; large user community. }\end{array}$} \\
\hline \multicolumn{3}{|c|}{$\begin{array}{l}2019 \text { Review } \\
\text { This is a subset of an entry made in } 2017 \text { for 'Gaming' which the Jury has split into four more } \\
\text { discrete entries. This entry for older games encourages greater consideration of the technical } \\
\text { complexities which arise from preservation of software and hardware environments. There is an } \\
\text { active specialist market for older games which enable preservation but also skews it around } \\
\text { commercial interests. The meaning of 'older' is open to interpretation but any game more than } 10 \\
\text { years from release should be included here especially if there are more recent releases. }\end{array}$} \\
\hline \multicolumn{3}{|c|}{$\begin{array}{l}\text { Additional Jury Comments } \\
\text { This is very closely related to the 'Old or non-current video games' item, but there are parallels } \\
\text { with the online gaming platforms: how do we capture the experience of play? This is much harder } \\
\text { than online gaming, where the social interactions occur in digital form. With appropriate } \\
\text { selection, appraisal and preservation, we can capture some of this through ephemera such as } \\
\text { gaming magazines of the } 80 \text { s and } 90 \text { s, for example, but much has already been lost. I'm focussing } \\
\text { on the negative here - it is still possible to preserve design materials, developer interviews, sales } \\
\text { data and games reviews, etc. but first-hand accounts of what it was actually like to play these } \\
\text { games are rare. }\end{array}$} \\
\hline \multicolumn{3}{|c|}{$\begin{array}{l}\text { By implication this category includes user generated content within games which is distinct from } \\
\text { the game itself. For example, the National Library of Scotland was approached to preserve a } \\
\text { Minecraft representation of Scottish cities. If you can preserve the game then preserving the user } \\
\text { generated content should be straightforward. But it's not clear who is doing that. }\end{array}$} \\
\hline
\end{tabular}




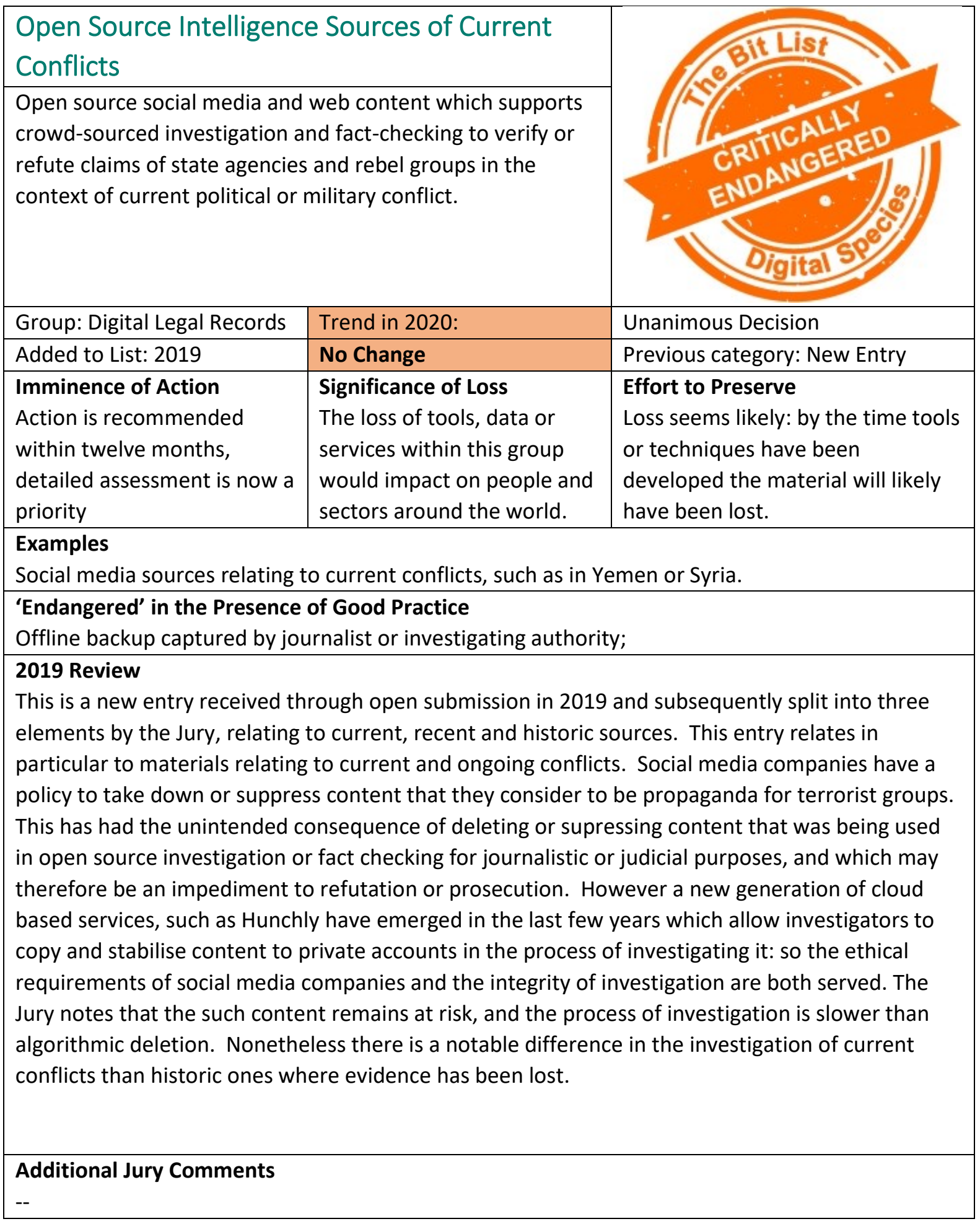




\begin{tabular}{|c|c|c|}
\hline \multicolumn{2}{|l|}{ Politically Sensitive } & \\
\hline \multicolumn{2}{|c|}{$\begin{array}{l}\text { Digital content where the knowledge to preserve exists and } \\
\text { there is no threat to obsolescence, but where political } \\
\text { interests may be served by elimination, falsification or } \\
\text { concealment. }\end{array}$} & \\
\hline Group: Political Data & Trend in 2020: & Consensus Decision \\
\hline Added to List: 2017 & Trend towards gr & Previously: Critically Endangered \\
\hline $\begin{array}{l}\text { Imminence of Action } \\
\text { Action is recommended } \\
\text { within twelve months, } \\
\text { detailed assessment is now a } \\
\text { priority }\end{array}$ & $\begin{array}{l}\text { Significance of Loss } \\
\text { The loss of tools, data or } \\
\text { services within this group } \\
\text { would impact on people and } \\
\text { sectors around the world. }\end{array}$ & $\begin{array}{l}\text { Effort to Preserve } \\
\text { It would require a major effort to } \\
\text { prevent losses in this group, such } \\
\text { as the development of new } \\
\text { preservation tools or techniques. }\end{array}$ \\
\hline \multicolumn{3}{|c|}{$\begin{array}{l}\text { Examples Online News; Social media and web-based campaigning; Social media relating to } 2016 \\
\text { UK/EU referendum; Promises made in Scottish independence referendum 2014; US } \\
\text { Environmental Data; UK Public Finance Initiative (PFI) documents; Recordings of Leinster House; }\end{array}$} \\
\hline \multicolumn{3}{|c|}{$\begin{array}{l}\text { 'Practically Extinct' in the Presence of Aggravating Conditions } \\
\text { Opaque terms and conditions that facilitate deletion or obfuscation; lack of access to web- } \\
\text { harvesting; significant lobby interest; change of administration; data resides in single jurisdiction; } \\
\text { reputational risk to collecting institution }\end{array}$} \\
\hline \multicolumn{3}{|c|}{ ‘Endangered’ in the Presence of Good Practice } \\
\hline \multicolumn{3}{|c|}{$\begin{array}{l}2019 \text { Review: The nature and extent of political campaigning online continues to become more } \\
\text { apparent. This has drawn attention to the manipulation of digital media but not explicitly the } \\
\text { issue of deliberate deletion, alteration or concealment. GDPR provides a pretext for the disposal } \\
\text { of records. The increased capability of archives to secure the content from outgoing governments } \\
\text { and ministers is a source of encouragement, such as in Canada accusations that the incoming } \\
\text { Liberal government had wiped the memory of the outgoing Conservative government were } \\
\text { shown to be unfounded. Nonetheless there is a pressing need for a deep and comprehensive } \\
\text { assessment of the risks faced by politically sensitive data and the impact which such deletions } \\
\text { have on the public good. That another year should have passed without such an assessment is a } \\
\text { matter of grave concern, suggesting that the trend is towards significantly greater risk }\end{array}$} \\
\hline \multicolumn{3}{|c|}{$\begin{array}{l}\text { Maybe it is not the duty of archives or libraries to preserve the falsification but to preserve the } \\
\text { constituent pieces to allow researchers to infer elimination, falsification or concealment. Web } \\
\text { harversting orgs will pick up web and possibly some social media. Will others pick up the rest? } \\
\text { Risk is high because some of the data will be in difficult to reach platforms. Some inevitable loss. } \\
\text { Is there a technological path to capturing and protecting this information before deletion or } \\
\text { manipulation? This could well be the basis for crowd funding and/ or crowd implementation. }\end{array}$} \\
\hline \multicolumn{3}{|c|}{$\begin{array}{l}2020 \text { Trend: } 2020 \text { has been a year of significant political and economic upheaval, in part because } \\
\text { of the pandemic though also because of popular protest and the outcomes of elections around } \\
\text { the world. Moreover it has been widely reported that senior officials in government have avoided } \\
\text { scrutiny and record-keeping laws by using self-deleting messaging applications. In these } \\
\text { circumstances politically sensitive records are likely to be at greater risk. }\end{array}$} \\
\hline
\end{tabular}




\begin{tabular}{|c|c|c|}
\hline \multicolumn{2}{|c|}{ Records of Local Government } & \\
\hline \multicolumn{2}{|c|}{$\begin{array}{l}\text { Records from local government (ie below the state level) } \\
\text { which are required for transparency and may be in many } \\
\text { diverse forms, but in which the local authority may lack the } \\
\text { capacity to manage the complex digital preservation } \\
\text { requirements that arise. }\end{array}$} & \\
\hline Grol & & nsensus Decision \\
\hline Adde & ater risk & Previously: new Entry \\
\hline $\begin{array}{l}\text { Imminence of Action } \\
\text { Action is recommended } \\
\text { within three years, with } \\
\text { detailed assessment in } 12 \\
\text { months }\end{array}$ & $\begin{array}{l}\text { Significance of Loss } \\
\text { The loss of tools, data or } \\
\text { services within this group } \\
\text { would impact on many } \\
\text { people and sectors. }\end{array}$ & $\begin{array}{l}\text { Effort to Preserve } \\
\text { It would require a major effort } \\
\text { prevent losses in this group, su } \\
\text { as the development of new } \\
\text { preservation tools or technique }\end{array}$ \\
\hline \multicolumn{3}{|c|}{$\begin{array}{l}\text { Examples Born digital records of small and medium-sized agencies; fasting-changing internal } \\
\text { manuals, advice or policies shared electronically; records of care services; Documentation } \\
\text { supporting long-lived contractual relations like Public Finance Initiatives; Organizational Slack } \\
\text { channels; network drives; EDRMS; Email. }\end{array}$} \\
\hline \multicolumn{3}{|c|}{$\begin{array}{l}\text { Lack of preservation infrastructure; conflation of backup with preservation; loss of authenticity or } \\
\text { integrity; Long-lived business processes; poor storage; churn of staff; significant volumes or } \\
\text { diversity of data; poorly developed digitization; ill-informed records management; poorly } \\
\text { developed migration or normalization; longstanding protocols or procedures that apply unsuitable } \\
\text { paper processes to digital materials; encryption; political instability; lack of sustained funding. }\end{array}$} \\
\hline \multicolumn{3}{|c|}{$\begin{array}{l}\text { Well managed data infrastructure; preservation enabled at the point of creation; carefully } \\
\text { managed authenticity; use of persistent identifiers; finding aids; well managed records } \\
\text { management processes; recognition of preservation requirements; strategic investment in digital } \\
\text { preservation; preservation roadmap; participation in digital preservation community. }\end{array}$} \\
\hline \multicolumn{3}{|c|}{$\begin{array}{l}2019 \text { Review This is a new entry which the Jury introduced in } 2019 \text { based on an earlier larger } \\
\text { entry for 'Records of long duration from Local Government or Other Government Agencies'. The } \\
\text { split is intended to allow greater concentration on the challenges that these different types of } \\
\text { agency face. Local government typically operates across a broad range of digital formats and } \\
\text { services but it is unclear, and unlikely that relatively small archival agencies are properly funded } \\
\text { locally to support the wide range of digital preservation requirements that arise. }\end{array}$} \\
\hline \multicolumn{3}{|c|}{ Additional Jury Comments } \\
\hline \multicolumn{3}{|c|}{$\begin{array}{l}\text { Additional Jury Comments } \\
\text { Significant research by the UK National Archives into Local Government Archives in England } \\
\text { underlines the digital skills shortages that exist, especially with respect to preservation. } \\
\text { There may be a benefit from splitting into a) legally required public record and b) additional } \\
\text { information that may enrich our digital preservation of society. My assumption was that the roles } \\
\text { and requirement for records management is clearly defined, but if this is not the case and there is } \\
\text { inadequate resource to match the requirement then the risk goes up. }\end{array}$} \\
\hline \multicolumn{3}{|c|}{$\begin{array}{l}2020 \text { Trend: } 2020 \text { has been a year of significant political and economic upheaval, putting } \\
\text { additional strain on local government and its agencies. In these circumstances already vulnerable } \\
\text { records are likely to be at greater risk. }\end{array}$} \\
\hline
\end{tabular}




\begin{tabular}{|c|c|c|}
\hline \multicolumn{2}{|c|}{ Records of Non-Gover } & \\
\hline \multicolumn{3}{|c|}{$\begin{array}{l}\text { Records of independent agencies and contractors that act } \\
\text { on behalf of the state in the delivery of public services, and } \\
\text { which may be present in many diverse forms, but for which } \\
\text { the NGO or contractors may lack the capacity to meet the } \\
\text { complex digital preservation requirements that arise, or may } \\
\text { have a business motive to minimize or ignore requirements } \\
\text { for the maintenance of the record }\end{array}$} \\
\hline Grol & Tre & nsensus Decision \\
\hline Adde & & ly: New Entry \\
\hline twelve months. & & \\
\hline \multicolumn{3}{|c|}{$\begin{array}{l}\text { Examples: Born digital records of small and medium-sized agencies; fasting-changing internal } \\
\text { manuals, advice or policies shared on intranets or EDRMS; records of care services; historic } \\
\text { guidelines and manuals which evidence 'best practice at the time'; Documentation supporting } \\
\text { long-lived contractual relations like Public Finance Initiatives; Organizational Slack channels; } \\
\text { network drives; EDRMS; Email }\end{array}$} \\
\hline \multicolumn{3}{|c|}{$\begin{array}{l}\text { Lack of preservation infrastructure; conflation of backup with preservation; loss of authenticity or } \\
\text { integrity; Long-lived business processes; poor storage; churn of staff; significant volumes or } \\
\text { diversity of data; poorly developed digitization specifications; ill-informed records management; } \\
\text { poorly developed migration or normalizations specifications; longstanding protocols or } \\
\text { procedures that apply unsuitable paper processes to digital materials; encryption; political } \\
\text { instability; lack of sustained funding; denial of responsibility; failure to include archives within } \\
\text { contract from commissioning agency. }\end{array}$} \\
\hline \multicolumn{3}{|c|}{$\begin{array}{l}\text { Well managed data infrastructure; preservation enabled at the point of creation; carefully } \\
\text { managed authenticity; use of persistent identifiers; finding aids; well managed records } \\
\text { management processes; application of records management standards; recognition of } \\
\text { preservation requirements at highest levels; strategic investment in digital preservation; transfer } \\
\text { protocols to public archive; participation in digital preservation community. }\end{array}$} \\
\hline \multicolumn{3}{|c|}{$\begin{array}{l}2019 \text { Review: This is a new entry which the Jury introduced in } 2019 \text { based on an earlier larger } \\
\text { entry for 'Records of long duration from Local Government or Other Government Agencies'. The } \\
\text { split is intended to allow greater concentration on the challenges that these different types of } \\
\text { agency face. Non-governmental organizations typically operates across a broad range of digital } \\
\text { formats and services acting on behalf of public sector. }\end{array}$} \\
\hline \multicolumn{3}{|c|}{$\begin{array}{l}\text { Additional Jury Comments: There may be a benefit from splitting this into legally required public } \\
\text { record and additional information that may enrich our digital preservation of society. This } \\
\text { assumes that the roles and requirement for records management is clearly defined, but if this is } \\
\text { not the case and there is inadequate resource to match the requirement then the risk goes up. }\end{array}$} \\
\hline \multicolumn{3}{|c|}{$\begin{array}{l}2020 \text { Trend: } 2020 \text { has been a year of significant political and economic upheaval, putting } \\
\text { additional strain on NGOs. In these circumstances already vulnerable records are likely to be at } \\
\text { greater risk. }\end{array}$} \\
\hline
\end{tabular}




\begin{tabular}{|c|c|c|}
\hline \multicolumn{2}{|l|}{ Smart Phone Apps } & \\
\hline \multicolumn{3}{|c|}{$\begin{array}{l}\text { Apps created for smartphones. Many are deprecated quickly } \\
\text { but others survive through multiple update cycles. It is hard } \\
\text { to maintain version control and often dependent upon the } \\
\text { company that publishes them. There is no clear agency or } \\
\text { mandate to record or collect. }\end{array}$} \\
\hline Group: Apps & Trend in 2020: & Consensus Decision \\
\hline Added to List: 2017 & No Change & Previously: Critically Endangered \\
\hline $\begin{array}{l}\text { Imminence of Action } \\
\text { Action is recommended } \\
\text { within } 12 \text { months, detailed } \\
\text { assessment is now a priority }\end{array}$ & $\begin{array}{l}\text { Significance of Loss } \\
\text { The loss of data, tools or } \\
\text { services within this group } \\
\text { would be felt globally. }\end{array}$ & $\begin{array}{l}\text { Effort to Preserve } \\
\text { Loss seems likely: by the time tools } \\
\text { or techniques have been } \\
\text { developed the material will likely } \\
\text { have been lost. }\end{array}$ \\
\hline \multicolumn{3}{|c|}{$\begin{array}{l}\text { Examples } \\
\text { London } 2012 \text { app; BBC Olympic app; Apps published for Apple iOS } 10 \text { or earlier }\end{array}$} \\
\hline \multicolumn{3}{|c|}{$\begin{array}{l}\text { 'Practically Extinct' in the Presence of Aggravating Conditions } \\
\text { Device dependence; poor documentation; uncertainty over IPR; short term contracts; lack of } \\
\text { skills, commitment or policy from corporate owners; rapid churn of OS; shifting business } \\
\text { requirements of app resellers; dependence on exotic or obsolete formats or OS processes; }\end{array}$} \\
\hline \multicolumn{3}{|c|}{$\begin{array}{l}\text { 'Endangered' in the Presence of Good Practice } \\
\text { Strong documentation; version control for code and compiled app; emulation enabled; designated } \\
\text { repository taking preservation responsibility and capable to deliver }\end{array}$} \\
\hline \multicolumn{3}{|c|}{$\begin{array}{l}2019 \text { Review } \\
\text { This entry was submitted in } 2017 \text { and has been retained to draw attention to the challenges of } \\
\text { software preservation and the extraordinary velocity of the market for apps. Given the speed of } \\
\text { change it is hard to see how digital preservation efforts can keep pace. It may help to split this } \\
\text { entry into different groups based on the platform though the risks would be largely the same. }\end{array}$} \\
\hline \multicolumn{3}{|c|}{$\begin{array}{l}\text { Additional Jury Comments } \\
\text { Old versions of apps are completely lost to most users: once you upgrade an app you typically } \\
\text { can't go back. Perhaps ios is more critical - at least with Android you can often get .apk from the } \\
\text { internet separate from the marketplace. The NSRL contains hundreds of thousands of mobile } \\
\text { applications which are not being actively preserved but could be if a mandate existed. An } \\
\text { extension to Legal Deposit might be possible. }\end{array}$} \\
\hline \multicolumn{3}{|c|}{$\begin{array}{l}\text { The faster we act the less we will lose. It is unlikely that there will ever be one agent with mandate } \\
\text { to collect and different apps available in different countries so a network of national organisations } \\
\text { would be needed. The companies that create these apps are the key to the licensing challenges } \\
\text { and conversation with them is necessary, though would need to happen immediately in order to } \\
\text { negotiate the right to preserve/escrow both apps, operating systems, documentation, and phone } \\
\text { development emulators. }\end{array}$} \\
\hline $\begin{array}{l}\text { Apps often provide a second } \\
\text { important, and arguably easi } \\
\text { significant as others. }\end{array}$ & jew on the primary data & $\begin{array}{l}\text { in many cases that data is more } \\
\text { is an eye-catching entry it is not as }\end{array}$ \\
\hline
\end{tabular}




\begin{tabular}{|c|c|c|}
\hline \multicolumn{2}{|c|}{$\begin{array}{l}\text { Unpublished Research Data from US Govt } \\
\text { Researchers }\end{array}$} & \\
\hline \multicolumn{2}{|c|}{$\begin{array}{l}\text { To prepare data for long-term archiving requires quite a bit } \\
\text { of time, and offices being shut down or moved with little } \\
\text { warning don't have time. }\end{array}$} & \\
\hline Group: Research Outputs & Trend in 2020: & Consensus Decision \\
\hline Added to List: 2019 & No Change & Previous category: New Entry \\
\hline $\begin{array}{l}\text { Imminence of Action } \\
\text { Action is recommended } \\
\text { within } 12 \text { months, detailed } \\
\text { assessment is now a priority }\end{array}$ & $\begin{array}{l}\text { Significance of Loss } \\
\text { The loss of tools, data or } \\
\text { services within this group } \\
\text { would impact on many } \\
\text { people and sectors. }\end{array}$ & $\begin{array}{l}\text { Effort to Preserve } \\
\text { It would require a major effort to } \\
\text { prevent losses in this group, such } \\
\text { as the development of new } \\
\text { preservation tools or techniques. }\end{array}$ \\
\hline \multicolumn{3}{|c|}{$\begin{array}{l}\text { Examples } \\
\text { Agencies that have closed or have had funding withdrawn from research initiatives. }\end{array}$} \\
\hline \multicolumn{3}{|c|}{$\begin{array}{l}\text { 'Practically Extinct' in the Presence of Aggravating Conditions } \\
\text { Lack of access to archival services; sudden or un-anticipated closure; loss of implicit knowledge } \\
\text { from destabilised or demoralised staff; encryption }\end{array}$} \\
\hline \multicolumn{3}{|c|}{$\begin{array}{l}\text { 'Endangered' in the Presence of Good Practice } \\
\text { Archival responsibility well developed; documentation; published through research channels. }\end{array}$} \\
\hline \multicolumn{3}{|c|}{$\begin{array}{l}2019 \text { Review } \\
\text { This unusual entry was submitted through open nomination process and assessed by Jury before } \\
\text { being included. It has significant overlaps with other entries in the research outputs group but } \\
\text { has been retained to draw attention to two realities: firstly that research outputs are not simply a } \\
\text { matter for academic institutions and that government is in fact a major producer of research data; } \\
\text { and secondly that politically instability and threats to the continuity of government services are a } \\
\text { significant preservation risk. The significant fact that this entry relates to the US does not mean } \\
\text { that other jurisdictions are immune from political instability. Instead it alludes to a concern } \\
\text { expressed by the Jury that politically inconvenient research outputs face particular and immediate } \\
\text { threats of which the digital preservation community should be cognisant. }\end{array}$} \\
\hline \multicolumn{3}{|c|}{$\begin{array}{l}\text { Additional Jury Comments } \\
\text { The Jury offered no other comments on this entry, and a number of members did not participate } \\
\text { in this assessment. }\end{array}$} \\
\hline
\end{tabular}




\begin{tabular}{|c|c|c|}
\hline \multicolumn{2}{|c|}{ Web domains with no legal deposit } & \\
\hline \multicolumn{2}{|c|}{$\begin{array}{l}\text { Web archiving is a recognized specialism within digital } \\
\text { preservation, able to capture large quantities of material } \\
\text { with routine and standards-based tools. But there are } \\
\text { significant issues of intellectual property rights associated } \\
\text { with website capture and republication. In many } \\
\text { jurisdictions, but by no means all, those obstacles are } \\
\text { overcome by regulations that enable a national library or } \\
\text { other 'legal deposit' agency to copy and preserve content. } \\
\text { Where no such permission exists, there is a significant risk of } \\
\text { loss. }\end{array}$} & \\
\hline Group: Web & Trend in 2020: & Consensus Decision \\
\hline Added to List: & & Previous category: New Entry \\
\hline $\begin{array}{l}\text { Imminence of Action } \\
\text { Action is recommended } \\
\text { within } 12 \text { months, detailed } \\
\text { assessment is now a priority }\end{array}$ & $\begin{array}{l}\text { Significance of Loss } \\
\text { The loss of tools, data or } \\
\text { services within this group } \\
\text { would impact on many } \\
\text { people and sectors. }\end{array}$ & $\begin{array}{l}\text { Effort to Preserve } \\
\text { Loss seems likely: by the time tools } \\
\text { or techniques have been } \\
\text { developed the material will likely } \\
\text { have been lost. }\end{array}$ \\
\hline \multicolumn{3}{|c|}{$\begin{array}{l}\text { Examples } \\
\text { Domains registered without a country code; domains with a country code but weak or } \\
\text { unenforceable legal deposit permission to harvest. }\end{array}$} \\
\hline \multicolumn{3}{|c|}{$\begin{array}{l}\text { 'Practically Extinct' in the Presence of Aggravating Conditions } \\
\text { Rapid churn of websites; lack of access to Internet Archive harvest; contentious content; } \\
\text { encryption; digital rights management; non-standard content management }\end{array}$} \\
\hline \multicolumn{3}{|c|}{$\begin{array}{l}\text { 'Endangered' in the Presence of Good Practice } \\
\text { Permissive approach to Legal deposit; }\end{array}$} \\
\hline \multicolumn{3}{|c|}{$\begin{array}{l}2019 \text { Review } \\
\text { This entry came about by Jury deliberation on entries to the open nomination process. It is } \\
\text { characterised by regulatory barriers rather than technical ones, though the pace of change in web } \\
\text { technologies as well as the growth of web content mean that significant technical challenges still } \\
\text { exist. The Jury also notes that local conditions are also a significant factor. For example, web sites } \\
\text { often also fall under public records legislation or are important elements of corporate records: } \\
\text { and so important parts of the web are harvested even when there is no explicit legal deposit } \\
\text { legislation. Moreover the Jury particularly recognizes the work of the Internet Archive to capture } \\
\text { and preserve content. Even so there are significant gaps in web archiving and in too many cases it } \\
\text { is regulation that is the barrier. }\end{array}$} \\
\hline Additional Jury Comments & & \\
\hline
\end{tabular}




\section{Practically Extinct}

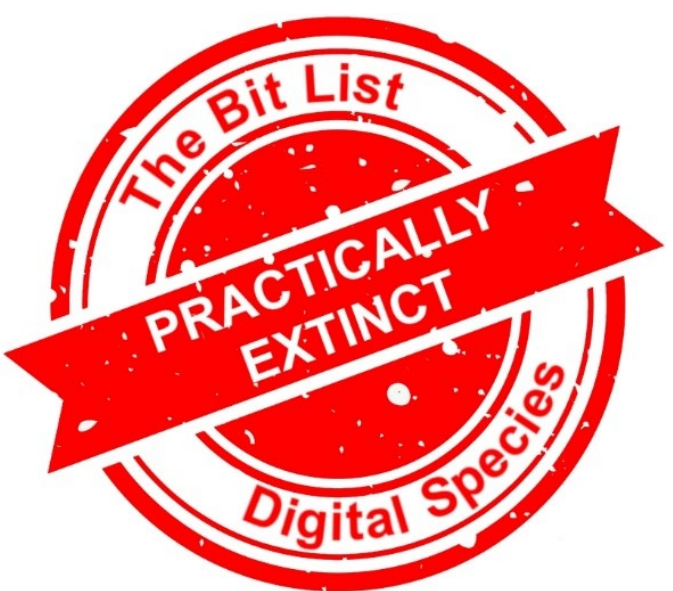

Digital materials are listed as Practically Extinct when examples cannot be identified or are inaccessible by most practical means and methods. It does not assume that the material is lost, but rather that loss is imminent and immediate action is required to avoid loss. It includes material where recovery is possible in very small samples but is impractical or has not been demonstrated at scale.

This classification includes Critically Endangered materials in the presence of aggravating conditions. 


\begin{tabular}{|c|c|c|}
\hline \multicolumn{2}{|c|}{$\begin{array}{l}\text { Legacy Interfaces and Services Offered Online } \\
\text { by Major Companies }\end{array}$} & \\
\hline \multicolumn{2}{|c|}{$\begin{array}{l}\text { Online services with unique interfaces that change regularly } \\
\text { and through those changes provide a different experience } \\
\text { AND different content to their users. }\end{array}$} & \\
\hline Group: Social Media & Trend in 2020: & Unanimous Decision \\
\hline Added to List: 2019 & No Change & Previous category: New Entry \\
\hline $\begin{array}{l}\text { Imminence of Action } \\
\text { Action is recommended } \\
\text { within } 12 \text { months, detailed } \\
\text { assessment is now a priority }\end{array}$ & $\begin{array}{l}\text { Significance of Loss } \\
\text { The loss of tools, data or } \\
\text { services within this group } \\
\text { would impact on people and } \\
\text { sectors around the world. }\end{array}$ & $\begin{array}{l}\text { Effort to Preserve } \\
\text { Loss seems likely: by the time tools } \\
\text { or techniques have been } \\
\text { developed the material will likely } \\
\text { have been lost. }\end{array}$ \\
\hline
\end{tabular}

\section{Examples}

Interfaces to Gmail, Facebook, Google Docs, Hotmail, Ask Jeeves, Tweetdeck, TurboTax, MySpace, Quicken Online, and many others

\section{'Critically Endangered' in the Presence of Aggravating Conditions}

Robust and extensive web archives with strong documentation of search algorithms, ranking and personalization of interfaces.

\section{Review}

This is a new entry received through the open submission process and assessed by the Jury prior to publication. There are several other entries around social media and the web which pertain to content: this entry highlights the configuration of interfaces and therefore the ever-changing arrangement and presentation of content. Personalization means that the same query can produce quite different results to different users at the same time; and the application of machine learning to behavioural surplus means the same may obtain different results at different points in time. That is over and above the rapid churn in the appearance of web interfaces. There is little appreciation of the implications for the use of online services, and the potential for manipulations that arise. Moreover, the digital preservation community, concerned historically with data rather than interface, has only rudimentary tools to address this challenge.

\section{Additional Jury Comments}

Some of the content/iterations of these likely preserved to some extent within existing web archives, but not as targeted collection efforts. As we've seen with myspace and other platforms where the platform producers decide to remove content or shut down rather quickly, it can be too late if this content hasn't been preserved already.

Why can we see how the online services behaved 5 years ago? Moreover, why can't we see the way they manipulated data to present content differently to how they now do such that the content we can access via them is different?

How far do we take this? The returns are likely to diminish. Who is taking responsibility to preserve? What are the platform creators doing to preserve this cultural history?

Some of this information is almost certainly lost already (some through deliberate erasure). 


\begin{tabular}{|c|c|c|}
\hline \multicolumn{2}{|c|}{ Non-standard Public Records } & \\
\hline \multicolumn{2}{|c|}{$\begin{array}{l}\text { Records created in the course of public administration and } \\
\text { subject to public records legislation but created on unofficial } \\
\text { channels and platforms and therefore subject to unlawful } \\
\text { destruction whether by accident or design. }\end{array}$} & \\
\hline Group: Digital Legal & Trend i & Unanimous Decision \\
\hline Adde & eater risk & Previous category: New Entry \\
\hline $\begin{array}{l}\text { Imminence of Action } \\
\text { Immediate action necessary. } \\
\text { Where detected they should } \\
\text { be stabilised and reported as } \\
\text { a matter of urgency }\end{array}$ & $\begin{array}{l}\text { Significance of Loss } \\
\text { The loss of tools, data or } \\
\text { services within this group } \\
\text { would impact on people and } \\
\text { sectors around the world. }\end{array}$ & $\begin{array}{l}\text { Effort to Preserve } \\
\text { Loss seems likely: by the time tools } \\
\text { or techniques have been } \\
\text { developed the material will likely } \\
\text { have been lost. }\end{array}$ \\
\hline \multicolumn{3}{|c|}{$\begin{array}{l}\text { Examples } \\
\text { Content and messages from cloud based instant messaging services (such as WhatsApp Telegram } \\
\text { or Snapchat) that pertains to public administration and is subject to public records legislation but } \\
\text { concealed from or inaccessible to archival agencies. }\end{array}$} \\
\hline \multicolumn{3}{|c|}{$\begin{array}{l}\text { ‘Critically Endangered' in the Presence of Good Practice } \\
\text { Archival pathway; public officials briefed on the nature of public records and the penalties for } \\
\text { illegal disposal; boundary between public and private correspondence; cloud services } \\
\text { administered transparently; export functions. }\end{array}$} \\
\hline \multicolumn{3}{|c|}{$\begin{array}{l}2019 \text { Review } \\
\text { This is a subset of an entry in the } 2018 \text { BitList for 'Digital Legal Records and Evidence' which the } \\
\text { Jury has decided to separate into four different entries in order to draw attention to the different } \\
\text { challenges and priorities that arise. The Jury has subsequently given this entry the strongest } \\
\text { indication of risk available. This group includes those records which may contain politically } \\
\text { damaging or uncomfortable realities and thus be at risk of deletion; and may be concealed from } \\
\text { archival agencies whether by accident or design. The judges note that the destruction of certain } \\
\text { classes of public records is unlawful, whether or not it is deliberate. }\end{array}$} \\
\hline \multicolumn{3}{|c|}{$\begin{array}{l}\text { Additional Jury Comments } \\
\text { This is a "small effort to fix" in terms of the technology to export data. But loss seems likely unless } \\
\text { there is stronger monitoring and enforcement of the policy around this. }\end{array}$} \\
\hline \multicolumn{3}{|c|}{$\begin{array}{l}\text { Agencies responsible for public record will not be able to completely control their public servants } \\
\text { use of unofficial channels (but could tighten) so need methods to obtain from unofficial channels. } \\
\text { Very important for public accountability and transparency of the state. }\end{array}$} \\
\hline \multicolumn{3}{|c|}{$\begin{array}{l}2020 \text { Trend: the 'pivot to digital' necessitated by the Pandemic has resulted in widespread } \\
\text { changes in workflow and in platform for the delivery of government, with significant amounts of } \\
\text { remote working. These changes happened rapidly often without time to consider the } \\
\text { preservation and record keeping implications. In these circumstances it seems reasonable to } \\
\text { suppose the risks have now expanded in size as well as scope. }\end{array}$} \\
\hline
\end{tabular}




\begin{tabular}{|c|c|c|}
\hline \multicolumn{2}{|c|}{ Older Open Source Intelligence Sources } & \\
\hline \multicolumn{2}{|c|}{$\begin{array}{l}\text { Older open source social media and web content which } \\
\text { supports crowd-sourced investigation and fact-checking to } \\
\text { verify or refute claims of state agencies and rebel groups in } \\
\text { the context of historic political or military conflict. }\end{array}$} & \\
\hline Group: Digital Legal Records & Trend in 2020: & Unanimous Decision \\
\hline Added to List: 2019 & No Change & Previous category: New Entry \\
\hline $\begin{array}{l}\text { Imminence of Action } \\
\text { Immediate action necessary. } \\
\text { Where detected they should } \\
\text { be stabilised and reported as } \\
\text { a matter of urgency }\end{array}$ & $\begin{array}{l}\text { Significance of Loss } \\
\text { The loss of tools, data or } \\
\text { services within this group } \\
\text { would impact on people and } \\
\text { sectors around the world. }\end{array}$ & $\begin{array}{l}\text { Effort to Preserve } \\
\text { Loss seems likely: by the time tools } \\
\text { or techniques have been } \\
\text { developed the material will likely } \\
\text { have been lost. }\end{array}$ \\
\hline \multicolumn{3}{|c|}{$\begin{array}{l}\text { Examples } \\
\text { Social media sources relating to the Arab spring }\end{array}$} \\
\hline \multicolumn{3}{|c|}{$\begin{array}{l}\text { 'Critically Endangered' in the Presence of Good Practice } \\
\text { Offline backup documented and available for recovery; }\end{array}$} \\
\hline \multicolumn{3}{|c|}{$\begin{array}{l}2019 \text { Review } \\
\text { This is a new entry received through open submission in } 2019 \text { and subsequently split into three } \\
\text { elements by the Jury, relating to current, recent and historic sources. This entry relates in } \\
\text { particular to materials published at the time of the 'Arab' spring. Social media companies had } \\
\text { initially taken little or no action with respect to social media content in conflict zones, taking the } \\
\text { view either that they were mere technical platforms and therefore not responsible for editorial; or } \\
\text { that the platforms were being used largely for a social good, loosening the control of the media } \\
\text { from oppressive regimes. However, as the Arab Spring progressed, the companies came under } \\
\text { significant pressure to monitor content with more care, in part because terrorist groups had } \\
\text { begun using the social media platforms for propaganda purposes. The social media companies } \\
\text { responded by implementing algorithms that removed or deleted content. This had the } \\
\text { unintended consequence of deleting or supressing content that was being used in open source } \\
\text { investigation for journalistic or judicial purposes and may have resulted in refutation or } \\
\text { prosecution. }\end{array}$} \\
\hline \multicolumn{3}{|c|}{$\begin{array}{l}\text { The Jury recognizes the duty of care that social media companies have towards their users and is } \\
\text { in no sense seeking to have that material re-published on the open web. But it notes the } \\
\text { unintended consequence for journalists and investigatory authorities from the rush to deletion. } \\
\text { This entry further underlines the relative fragility of all social media content. }\end{array}$} \\
\hline Additional Jury Comments & & \\
\hline
\end{tabular}




\begin{tabular}{|c|c|c|}
\hline \multicolumn{2}{|c|}{$\begin{array}{l}\text { Pre-WWW Videotex Data Services and Bulletin } \\
\text { Board Services }\end{array}$} & 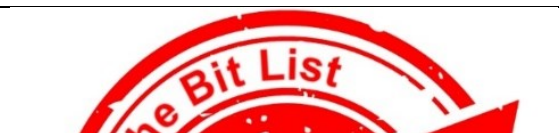 \\
\hline \multicolumn{2}{|c|}{$\begin{array}{l}\text { Pre WWW telephone and television information services } \\
\text { that allowed a degree of user interaction and data retrieval } \\
\text { with modem-based two way communication. }\end{array}$} & \\
\hline Group: Sound \& Vision & Trend in 2020: & Unanimous Decision \\
\hline Added to List: 2017 & No Change & $\begin{array}{l}\text { Previous category: Practically } \\
\text { Extinct }\end{array}$ \\
\hline $\begin{array}{l}\text { Imminence of Action } \\
\text { Action is recommended } \\
\text { within } 12 \text { months, detailed } \\
\text { assessment is now a priority }\end{array}$ & $\begin{array}{l}\text { Significance of Loss } \\
\text { The loss of tools, data or } \\
\text { services within this group } \\
\text { would impact on people and } \\
\text { sectors around the world. }\end{array}$ & $\begin{array}{l}\text { Effort to Preserve } \\
\text { Loss seems likely: by the time tools } \\
\text { or techniques have been } \\
\text { developed the material will likely } \\
\text { have been lost. }\end{array}$ \\
\hline \multicolumn{3}{|c|}{$\begin{array}{l}\text { Examples } \\
\text { Prestel, Minitel, VidiTel and Videotex NL, Alex, BelTel, FidoNet }\end{array}$} \\
\hline \multicolumn{3}{|c|}{$\begin{array}{l}\text { ‘Critically Endangered’ in the Presence of Good Practice } \\
\text { Offline backup documented and available for recovery; }\end{array}$} \\
\hline \multicolumn{3}{|c|}{$\begin{array}{l}2019 \text { Review } \\
\text { This entry was first published in } 2017 \text { and there has been no evidence to document any change in } \\
\text { the initial classification that such data was practically extinct. There may be examples residing in } \\
\text { offline backups of services taken at the time, but these are likely to have deteriorated rapidly. } \\
\text { Therefore the Jury calls on anyone with such collections to act quickly to stabilise and recover } \\
\text { content. }\end{array}$} \\
\hline \multicolumn{3}{|c|}{$\begin{array}{l}\text { Although there is no structured collection of this material many individuals have archives and a } \\
\text { campaign of the nature of 'Missing believed Wiped' might be effective }\end{array}$} \\
\hline \multicolumn{3}{|c|}{$\begin{array}{l}\text { Almost impossible to get this data back (we can hope for some disks to show up one day that have } \\
\text { traces on them). From a cultural studies point of view, it's a huge loss. }\end{array}$} \\
\hline \multicolumn{3}{|l|}{ Appeal to the crowd? } \\
\hline $\begin{array}{l}\text { This is also something that li } \\
\text { forums were a place of comr }\end{array}$ & o community archives and & $\begin{array}{l}\text { nmunity heritage - early online } \\
\text { ty creation. }\end{array}$ \\
\hline
\end{tabular}




\begin{tabular}{|c|c|c|}
\hline \multicolumn{2}{|c|}{$\begin{array}{l}\text { Pre-WWW ViewData and TeleText Services } \\
\text { where no archival agency has captured and } \\
\text { retained the signal }\end{array}$} & \\
\hline \multicolumn{2}{|c|}{$\begin{array}{l}\text { Pre-WWW television information services broadcast within } \\
\text { the TV signal that allowed a degree of search and retrieval } \\
\text { of up-to-date information, based on TeleText or ViewData } \\
\text { technologies and variants. }\end{array}$} & \\
\hline Group & Tren & onsensus Decision \\
\hline Adde & & \\
\hline months & $\begin{array}{l}\text { Significance of Loss } \\
\text { The loss of tools, data or } \\
\text { services within this group } \\
\text { would impact on many } \\
\text { people and sectors. }\end{array}$ & fort to Preserve \\
\hline \multicolumn{3}{|c|}{$\begin{array}{l}\text { Examples } \\
\text { AerTel; Electra; MetroText; Antiope-based systems; Ceefax; TeleText }\end{array}$} \\
\hline \multicolumn{3}{|c|}{$\begin{array}{l}\text { ‘Critically Endangered' in the Presence of Good Practice } \\
\text { Captured within on-air broadcast recordings; active research and recovery programme }\end{array}$} \\
\hline \multicolumn{3}{|c|}{$\begin{array}{l}2019 \text { Review } \\
\text { A number of important developments have been reported since this entry was made in } 2017 \\
\text { which give hope that collections can be recovered and re-used under certain circumstances. Live- } \\
\text { capture of broadcast output at the BBC and British Film Institute embed the signals that can be } \\
\text { assembled to access the teletext content. Methods to recover such signals have been } \\
\text { demonstrated meaning that, where the appropriate broadcast archive exists the signal can be } \\
\text { recovered. It is not yet fully clear how such a signal could be made searchable or made available } \\
\text { at scale. Nonetheless research is progressing on how this may be made possible. Consequently, } \\
\text { this entry is now progressing towards improvement, provided the different threads of active } \\
\text { research can be brought together in a timely manner. }\end{array}$} \\
\hline \multicolumn{3}{|c|}{$\begin{array}{l}\text { Additional Jury Comments } \\
\text { From a cultural studies point of view, it's a huge loss: an important source of information about } \\
\text { news and social mores of the time. There is progress to report on this entry, meaning that } \\
\text { elements of the problem have been resolved? Major national agencies have collections of off-air } \\
\text { recorded television on videotape carriers, which are likely to contain the teletext data. Few if any } \\
\text { have undertaken substantial extraction and preservation of the teletext in its own right, although } \\
\text { many have digitised videotape carriers to digital file formats which are now under preservation. } \\
\text { An active teletext enthusiast community has developed and has created programmatic solutions } \\
\text { to the extraction of the teletext from the video files, and emulation of teletext display. A next step } \\
\text { could be a collaboration between the official agencies and the enthusiast community to develop a } \\
\text { systematic programme to extract teletext from off-air recordings for both preservation and access } \\
\text { via emulation. }\end{array}$} \\
\hline
\end{tabular}


The Digital Preservation Coalition

11 University Gardens,

Glasgow G12 8QQ

Scotland

www.dpconline.org

Info@dpconline.org

The Digital Preservation Coalition (DPC)

exists to secure our digital legacy.

We enable our members to deliver resilient longterm access to digital content and services, helping them to derive enduring value from digital assets and raising awareness of the strategic, cultural and technological challenges they face. We achieve our aims through advocacy, community engagement, workforce development, capacitybuilding, good practice and good governance.

(C) Digital Preservation Coalition 2020 